\title{
QUEEN'S
UNIVERSITY
BELFAST
}

\section{Course Choice and Achievement Effects of a System-wide Vocational Education and Training Voucher Scheme for Young People}

McVicar, D., \& Polidano, C. (2018). Course Choice and Achievement Effects of a System-wide Vocational Education and Training Voucher Scheme for Young People. Educational Evaluation and Policy Analysis, 40(4), 507-530. https://doi.org/10.3102/0162373718782648

\section{Published in:}

Educational Evaluation and Policy Analysis

\section{Document Version:}

Peer reviewed version

Queen's University Belfast - Research Portal:

Link to publication record in Queen's University Belfast Research Portal

\section{Publisher rights}

Copyright 2018 SAGE. This work is made available online in accordance with the publisher's policies. Please refer to any applicable terms of use of the publisher.

\section{General rights}

Copyright for the publications made accessible via the Queen's University Belfast Research Portal is retained by the author(s) and / or other copyright owners and it is a condition of accessing these publications that users recognise and abide by the legal requirements associated with these rights.

Take down policy

The Research Portal is Queen's institutional repository that provides access to Queen's research output. Every effort has been made to ensure that content in the Research Portal does not infringe any person's rights, or applicable UK laws. If you discover content in the Research Portal that you believe breaches copyright or violates any law, please contact openaccess@qub.ac.uk. 


\title{
Course Choice and Achievement Effects of a System-wide Vocational Education and Training Voucher Scheme for Young People
}

\author{
Professor Duncan McVicar \\ Queen's Management School, Queen's University Belfast, \\ Riddel Hall, 185 Stranmillis Road, Belfast BT9 5EE, United Kingdom. \\ +44(0)2890974809, d.mcvicar@qub.ac.uk.
}

Cain Polidano

Senior Research Fellow,

Melbourne Institute of Applied Economic and Social Research,

Faculty of Business and Economics Building, The University of Melbourne, 111 Barry

Street, Carlton 3010, Australia

+61383442102, cainp@unimelb.edu.au.

Affiliate of the Australian Research Council Centre of Excellence for Children and Families over the Life Course.

This Version: May 2018

Keywords: vocational education and training; voucher; course choice; achievement.

JEL classification: H44, I21, I22, I28 


\begin{abstract}
Vocational education and training provision for young people is a crucial but often maligned part of the wider education sector. A common criticism, and motivation for numerous reforms across countries where training is predominantly classroom-based, is that too much training is low quality and unrelated to skill needs. This paper examines the effects of a major Australian reform - replacing a centrally-planned model with a system-wide voucher scheme - aimed at addressing these weaknesses. The reform led to large increases in private college enrolments, improved match between course choice and employer demand, and improved student achievement, with no adverse impact on equity.
\end{abstract}




\section{Introduction}

Post-secondary VET provides young people, including early school leavers, with accessible opportunities to continue education beyond school. Positive spillovers and borrowing constraints are among the motivations for extensive public funding of the sector (Stevens 1999). A major challenge for government; however, is allocating public funding in a way that promotes training that is high quality and relevant to skill needs. This is most acute for VET in countries, such as the United States, England, New Zealand and Australia, where the allocation of funding to VET is mostly not linked to the attainment of employment (apprenticeships). Instead, post-secondary VET in these countries is predominantly classroom-based training in public colleges with complicated and over-lapping funding arrangements that have been subject to frequent and often piecemeal reform. ${ }^{1}$ Recent assessments of these VET systems, which in part blame existing funding models for persistent skill shortages and poor-quality training (e.g. Wolf, 2011; US Department of Education, 2012), suggest in some cases that the challenge remains unmet.

Part of the problem is that there are strongly held beliefs on all sides about the extent to which, and how, market mechanisms should be employed in allocating public funding to VET providers. This is exacerbated by difficulties in comparing institutional impacts on outcomes across countries $^{2}$ and a lack of credible quantitative evaluations of past VET reforms within countries. To begin to fill this gap, this paper uniquely provides detailed evidence on the impacts of a 'big-bang' system-wide reform that introduced market mechanisms to postsecondary VET. Specifically, this paper examines impacts of a major national reform in the Australian state of Victoria - introduced earlier than in other Australian states - that replaced a centralised supply-driven funding model with a broad-based voucher scheme that linked funding to student course choice, including the choice of courses with private colleges. By quantifying the impacts of market-based reforms in Victoria, this study will help build an 
evidence base to inform reforms elsewhere; without which, it is difficult to build a case, execute and maintain reforms in the face of opposition from vested interests. In Victoria, industry, public colleges and the media all cast doubt about whether the reforms could lift training quality and alleviate long-standing skill shortages. ${ }^{3}$ Due in part to the negative media, voucher schemes subsequently introduced in other Australian states included restrictions on course choice.

As far as we are aware, this is the first study to estimate the impacts of a broad-based voucher scheme in VET on training relevance, measured as the alignment of course choice with information available on skill need, and academic achievement, a proxy for quality. Previous studies on the impacts of VET voucher schemes (Schwerdt et al., 2012; Hidalgo et al., 2014) examined small-scale targeted programs that complemented existing VET funding systems and therefore provide little guidance on the likely outcomes of system-wide reforms. Whether these reforms improved life-time earnings is outside the scope of this study, mainly because the data required are not currently available.

This study also makes an important general contribution to the wider educational voucher literature by examining whether institutional characteristics that are supportive of disadvantaged groups are sufficient to ensure that any positive course choice and achievement impacts are widely shared. In the main, evidence to date on school choice reforms points to benefits that are not shared equally (see Epple et al. (2015) for a review). One explanation is that disadvantaged groups don't benefit because of selection effects (by schools and families) that increase segregation (Hsieh and Urquiola, 2006). Another is that they have difficulty accessing and utilising information on available education options (Levin, 1991; Ladd, 2002; Hastings and Weinstein, 2008). Under the conditions examined in this study there is little scope for selection - admission to a VET course is on a first-come-first-served basis, with restrictions on cream-skimming and fee caps — and information on skill needs (skill shortages) 
is easily understood and freely available online. At least some of these characteristics are replicable in other educational contexts.

The remainder of the paper is set out as follows. Section 2 provides institutional details for the VET sectors in the rest of Australia and for Victoria pre and post-reform. Section 3 briefly discusses potential mechanisms for reform impacts. Section 4 describes the data and defines the outcome measures. Section 5 discusses the empirical approach and related identification issues. Sections 6 and 7 discuss the findings relating to course choice and educational achievement, respectively. Section 8 discusses sensitivity analysis and Section 9 concludes. Additional data details and results are presented in a Supplementary Appendix.

\section{VET in Australia and the Victorian Training Guarantee (VTG)}

The Australian schooling system is similar to other English-speaking countries in that the student body is unstreamed and the upper-secondary curriculum is geared towards preparation for university study (study that leads to a 3-year bachelor degree). For those who do not have the academic credentials or desire to attend university, including the $20 \%$ who leave school without attaining an upper-secondary school qualification (Australian Bureau of Statistics, 2016), VET is the main avenue to acquire post-school qualifications. The rate of participation is high, with around $40 \%$ of young people enrolling in a post-secondary VET course by age of 25 (Polidano and Ryan 2016).

Compared to university study, post-secondary VET courses are highly heterogeneous, with around 1,500 nationally accredited courses available at different levels (International Standard of Education Classification (ISCED) 1997 level 2C, 3C, 4B and 5B) geared towards preparing students for specific occupations. To attain qualifications students must demonstrate minimum competency in performing general and job-specific tasks that are prescribed in national training packages. National training packages are assembled by national skills councils that comprise representatives from government and employer groups. Except for apprenticeships and 
traineeships (which require an employment contract) there is no requirement in training packages for competencies to be met through workplace learning. At present, there is no grading of students to gauge the level of skill proficiency attained beyond pass/fail. Although minimum training standards are set at a national level, each of the six states and two territories is responsible for funding and administering their own VET sector.

Historically, states used a centrally-planned model for funding VET, one where fixed budget allocations were made at the course level across public providers (Technical and Further Education colleges (TAFEs), Adult and Community Education (ACE) centres and dual sector universities) based on historical enrolments and skill forecasts. Because VET is highly modularised, enrolments commence throughout the academic year and the limited numbers of places available pre-reform were rationed on a first-come-first-served basis. In practice, students could apply to multiple courses at multiple colleges at the same time and accept their offer of choice. Students who missed out on an offer from their preferred course at their preferred college could accept a place in the same course at a less preferred college, a less preferred course in their preferred college or re-apply the following year. There were no restrictions on the number of applications that could be made. As part of national reforms in 2008, all Australian states agreed to introduce demand-driven models where funding follows student choice. Victoria was the first state to implement these reforms from July 1 2009, which for 15-19 year-olds went by the name of the Victorian Training Guarantee (VTG). ${ }^{4}$ Until July 2012 when South Australia introduced its own reforms, all other states continued to operate their centrally-planned funding models..$^{5}$ The Victorian reforms therefore represent a unique natural experiment on systemic VET reform which can be evaluated using standard differencein-differences methods. Note these reforms covered all age groups, but were most extensive for 15-19 year olds - the age group for which engagement in post-secondary VET is most common - on whom this paper focuses. 
In essence, the VTG triggered three changes: the uncapping of the number of publiclyfunded places available to 15-19 year-olds, the linking of funding to student choice rather than provider capacity and government target areas, and the introduction of additional competition for funding from private colleges. By uncapping the number of publicly-funded places, individual providers were free to decide on the number of course admissions. The VTG did not affect public funding of the classroom component of apprenticeships and traineeships, which from 1998 had operated under a separate demand-driven system, including the freedom for employers to choose training with private colleges. ${ }^{6}$ During the period of analysis, all other arrangements remained much the same for 15-19 year-olds in Victoria (and elsewhere), including the course subsidy levels and the process of course admission described above. ${ }^{7}$

An additional interesting aspect of this reform, in contrast to educational contexts where broad-based vouchers have been introduced previously, is that there are strong regulatory safeguards in Australian VET that aim to ensure equality of access. First, during the period of analysis, the ability of providers to raise prices in response to increased demand was limited by fee caps for publicly-funded VET courses that typically restricted fees charged direct to students to less than $\mathrm{A} \$ 1000$ per year for a full-time course. ${ }^{8}$ A potential downside of the price caps is that they may have dampened the incentive for colleges to innovate in response to increased competition and instead encouraged cost cutting and reduced training quality, although minimum training standards are set centrally and there is a monitoring system in place. Second, colleges have limited ability to cream-skim because there is little personal information made available in advance to providers on which to select students - open access is a defining feature of the Australian VET sector - which means that admission is typically made on a first-come first-served basis. Further, the incentive to cream-skim is reduced by registration requirements that compel colleges, including private colleges, to comply with 
equity principles. ${ }^{9}$ Depending on the circumstances of the student, extra subsidies are also available to colleges to meet the extra cost of catering for 'high needs learners'.

Students who miss out on a subsidised place in training can enrol in an unregulated and unfunded 'fee-for-service' VET course, for which private colleges compete alongside public colleges in all states, although few 15-19 year olds take this route and consequently they are not part of the administrative collection used in this study. The best available data from the Longitudinal Survey of Australian Youth (LSAY), a large nationally representative survey of 15 year-olds (in 2003) tracked annually to age 25, suggests that private fee-for-service enrolments prior to the VTG (2005-07) represented at most 9\% of all 17-19 year-old VET enrolments. $^{10}$

\section{Potential Mechanisms}

Course choice and educational achievement (in this case completion) can be thought of in terms of an underlying discrete-choice human capital framework in which potential students make enrolment decisions, and decisions to stay the course given initial enrolment, based on their perception of the expected course benefits and costs. Such a framework suggests several mechanisms through which the VTG might impact on course choice and achievement, including compositional changes in the student body, compositional changes on the supply side (Friedman, 1962; Anderson, 2005; Blochliger, 2008; Bettinger et al., 2010; Demming et al., 2012; Rosenbaum and Rosenbaum, 2013), differences between students and government in the information used to assess labour market needs (Lavy, 2006; Jensen, 2010; OECD, 2010), disproportionate student weighting of consumption benefits of VET (Oreopoulos \& Salvanes, 2011; Baker et al., 2017), competition impacts on quality and other aspects of provision (Friedman, 1962; Hoxby, 2003; Anderson, 2005; Figlio and Hart, 2014; Böhlmark and Lindahl, 2015), and, for achievement, knock-on effects of VTG-induced changes in course choices and match quality (Bound and Turner, 2011). Additionally, there may be less scope post-reform for 
funding allocations to be affected by inertia on the part of policy makers or lobbying by incumbent providers.

Together these potential mechanisms point to VTG impacts of uncertain sign on both outcomes, hence the importance of credible empirical evidence. As part of our empirical strategy, we first estimate the overall reform effect - the net effect of all these mechanisms using difference-in-differences estimation, before exploring the role of these individual mechanisms by adding additional controls that proxy them in a step-wise manner.

\section{Data}

The main dataset used in the analysis is the VET Provider Collection (VETPC), an annual administrative dataset containing the population of all VET enrolment activity in Australia, except for fee-for-service enrolments with private colleges. The VETPC contains detailed course, student and college information, and a unique student-course identifier that allows enrolments to be tracked across time and, in most cases, through to completion.

The sample consists of all new enrolments among 15-19 year-olds - as of January $1^{\text {st }}$ in the year of enrolment, which determines VTG eligibility - who are no longer in secondary school and who commenced study in 2006 to 2009 (pre-reform) or 2010 to 2012 (post-reform). 2009 is treated as pre-reform despite the fact that the reforms were introduced in July 2009 because most enrolments occur at the start of the Australian academic year, i.e. January/February. Also note that post-reform counterfactual outcomes are potentially affected by the introduction of South Australian VET reforms in July 2012. Sensitivity to excluding both periods is examined in section 8 .

Table 1 summarises new enrolments in the sample. Enrolments in Victoria grew from 62,179 in 2009 , the final pre-reform period, to 116,015 by 2012 , an $86 \%$ increase. In contrast, there were only minor increases in enrolment in the rest of Australia over this period - from 160,718 in 2009 to 165,167 in 2012 , or a $3 \%$ increase. Importantly, some of the courses that 
experienced the largest enrolment increases (more than 500 enrolments annually) were in areas of national skill shortage; including courses that prepare students for work as child care workers, plumbers, hairdressers, electricians, cooks and child care managers (Table A5 in the Supporting Material). The growth in the number of enrolments in Victoria over this period is evenly split between public and private colleges, although private enrolment growth is from a much lower base. The decline in private college enrolments in both Victoria and the rest of Australia in 2008 is due to a decline in new apprenticeships related to the slowing of GDP growth that coincided with the global financial crisis. Note there is no noticeable increase or decrease in post-announcement but pre-reform enrolments in Victoria (August 2008-June 2009), which otherwise might suggest anticipation effects.

Table 2 presents sample means for student, college and course controls used in the analysis. Note there are only minor pre-reform differences in student characteristics between Victoria and the rest of Australia. Also note that the huge increase in enrolment in Victoria over this period was not drawn disproportionately from any one socio-economic or demographic group, with only minor impacts on a wide range of observed student characteristics.

\subsection{Outcome variables}

VTG impacts are examined on two key outcomes: the alignment of course choice with skill demand, and academic achievement, here interpreted as a (conditional) proxy for training quality. For course choice, two measures of 'fit' with labour market needs are derived using external data sources that are linked to course choices in the VETPC. Each year of the analysis, course enrolments are linked to information on labour market needs available at the start of the year (when most enrolments are made). In using the latest information available at the time of enrolment, the implicit assumption is that students make naïve forecasts of course outcomes based on current course information (Ryoo and Rosen, 2004; Heckman et al., 2006). 
The first measure of labour market needs is a binary indicator for whether the occupation the course is designed to prepare students for is on a national skills shortage list. ${ }^{11}$ Skill shortage lists are prepared annually (usually published in August) by the federal government, based primarily on employer surveys and skill forecasts. Over the period of analysis, around $10 \%$ of all occupations were identified as being in national shortage, although there were distinct changes in the occupations and number of occupations on the list. The 2009-10 list, which is the one available at the start of 2010, listed around half the number of occupations compared to the previous year, reflecting the slowing of growth in Australia following the onset of the global financial crisis. When using the skill shortage measure, the analysis excludes around $10 \%$ of enrolments that are in general and mixed field courses, such as numeracy and literacy and employment skills courses, that are not designed to prepare students for a particular occupation.

The second course choice measure is a continuous variable constructed from estimated earnings premia associated with the most recent graduates in each national qualification level and field of study combination. ${ }^{12}$ These are estimated using annual earnings data from the Student Outcomes Survey (SOS), a large and nationally representative survey of VET graduates conducted in the year following course completion. ${ }^{13}$ The sampling frame for the SOS is the population of VET completers in the preceding year drawn from the VETPC dataset described above, and includes updated information on student characteristics and current labour market outcomes, including weekly earnings for those employed. ${ }^{14}$ Specifically, these data are used to estimate a log wage regression for completers aged 15-25 years at the time of survey on dummies for course-level and field-of-study combinations, with resulting coefficients interpreted as the average expected earnings premia from different course choices, conditional upon observed student controls and on finding employment in the year after study. It is important to point out that although the continuous nature of this measure may better 
capture the extent of skill demand, course-level graduate earnings information was not readily available to students during the period of analysis.

The VETPC data are also used to construct two measures of completion which, given VET qualifications in Australia are pass/fail, are the only available measures of educational achievement. The first completion measure is a binary indicator equal to 1 if the student has passed the course by the end of the year following entry, and 0 otherwise. Those who enrol in the first half of the year are therefore tracked for 18-24 months, which is beyond the typical course duration of 12-18 months. Some of those who enter in the second half of the year are tracked for less than 18 months, and some of these are treated as right censored given that the data do not distinguish within-year between those who dropped out and those who are still enrolled but yet to complete. In practice, right censoring affects enrolments in both Victoria and the rest of Australia and, if anything, the post-treatment growth in second semester enrolments in Victoria would tend to negatively bias any estimated completion effect in Victoria using this measure.

The second completion measure is module (or subject) completion, which for a given course enrolment is the proportion of module enrolments that a student passes from the time of enrolment to the end of the following year. This is designed to reduce the right censoring problems discussed above, given that most students enrol in multiple modules in a semester typically lasting less than six months. This variable also helps to address the argument that some students enrol in a course only to learn a set of skills linked to a specific subset of modules, for example, to meet current job needs (see Mark and Karmel, 2010). Further details on enrolments, variable definitions and estimated course wage premia are contained in the Supplementary Appendix.

\section{Identification and estimation}


In common with many previous school choice studies, differences across space are exploited to identify impacts. In particular, differences in the timing of national reform implementation between Victoria and the rest of Australia, which occurred for exogenous political reasons, are exploited here using a standard difference-in-differences approach (see Blundell and Costa Dias, 2009). Specifically, linear regressions of the following form are estimated:

$$
y_{i s t}=\tau_{s}+\lambda_{t}+\delta\left(\text { Vic }_{i} \text {. Post } t\right)+\beta X_{i t}+\varepsilon_{i s t}
$$

where,

$\tau_{s}$ are state fixed effects;

$\lambda_{t}$ are year and month of enrolment fixed effects;

$\delta$ is the average treatment effect on the treated (ATT);

$V i c_{i}$ is a dummy variable for whether individual $i$ 's enrolment was in the state of Victoria;

Post $_{t}$ is a dummy variable for whether the enrolment is in the post-reform period;

$X_{i t}$ contains individual characteristics, including personal, college and course choice characteristics;

$\varepsilon_{i s t}$ is a stochastic error term.

As observed in Table 1, the post-reform enrolment growth was ongoing, which suggests other treatment effects may vary over the post-reform period. To test this, a dynamic treatment effects model is also estimated by extending equation (1):

$$
y_{i s t}=\tau_{s}+\lambda_{t}+\sum_{p=2010}^{2012} \delta_{p}\left(V i c_{i} \cdot p\right)+\beta X_{i t}+\varepsilon_{i s t}
$$

where $p$ is a series of year dummy indicators for each of the post-reform periods. 
A feature of our approach is the estimation of treatment effects under a range of assumptions regarding counterfactual outcomes. Under the standard difference-in-difference approach (implicit in equations 1 and 2), outcomes in the treatment group (Victoria) are assumed to follow a path that is parallel to that of the control group (Rest of Australia) in the absence of the reform. This is a restrictive and untestable assumption. In this study, we test the robustness of our results to alternative counterfactual trend assumptions. Specifically, in the main text we follow Jayachandran et al., (2010) and Groen and Polivka (2008) by also estimating (1) under a linear diverging trend assumption. That is, in the absence of the reform, the treatment group outcomes are assumed to linearly diverge from the control group trajectory at a rate that is consistent with any divergence pre-reform (2006-09). ${ }^{15}$ This is implemented (in equation 1) by including linear state-specific trend terms. ${ }^{16}$ In the sensitivity analysis, we also estimate results under non-linear diverging trend assumptions. Where there are no diverging trends pre-reform, results under both assumptions will be identical.

\subsection{Potential Threats to Identification of Causal Impacts}

Identification of causal impacts are contingent upon there being no other shock that differentially affected treatment and control groups over the period of analysis. There were no other major state-specific VET reforms over this period, and all states but one continued to operate the same funding models that had existed at the time of the national agreement on VET reform in 2008 without any subsequent reforms. The partial exception is South Australia, which introduced its own voucher scheme in July 2012. Sensitivity analysis tests the robustness of the results to the reforms in South Australia by omitting the second half of 2012 from the analysis. One possible threat to identification, however, is the introduction of an Australia-wide requirement in 2010 for all youth to remain in study until age 17, which may have affected Victoria differently because its minimum school leaving age was higher, at 16, than in many other states. To test whether this affects the results, models are re-estimated without those who 
enrol at age 17 or younger. Results are presented in section 8. Another potential threat is differential economic shocks from the global financial crisis. However, it is important to stress that Australia was relatively unaffected by this crisis, with continued, albeit slower economic growth in 2008 and 2009. Nonetheless, controls for annual unemployment rates at the local government area are included in an effort to control for any asymmetric shocks from this source. A further test for differential state-level economic shocks is conducted by limiting the sample to enrolments in two neighbouring towns either side of the Victoria-New South Wales (NSW) border, for which such shocks are less likely. Results are presented in section 8 .

Although anticipation effects between announcement (August 2008) and implementation (July 2009) seem unlikely on the supply side, they seem at least possible on the demand side. For example, some Victorian 15-19 year olds may have waited for the VTG to access their course of choice rather than enrol in another publicly-funded or fee-for-service course. This could impact both course choice and completion. But as discussed above there is little evidence for such an effect. If anything, enrolments in Victoria slightly increased in the first half of 2009. Nevertheless, the robustness of estimates to announcement effects is addressed further in section 8 where results are estimated with the omission of enrolments from August 2008 until December 2009.

A necessary condition to estimate the impacts of the VTG for a student body with given characteristics, i.e. the ATT, is that there are no relevant, asymmetric, unobserved changes in the composition of students. This is not directly testable, but the stability of observable characteristics between the pre and post-reform periods offers some reassurance (see Table 2). One potential threat here is cross-border VET commuting into Victoria induced by the VTG. In practice, however, this is not a major concern because, with the exception of the towns of Albury and Wodonga that straddle the Victoria-NSW border, few people live anywhere near the Victorian border. Table 2 shows that less than 3 percent of people studying in Victoria have 
an interstate residential address, and this proportion is lower in the post-reform period. Nevertheless a control for this is included.

All standard errors are cluster-robust, with clustering at the state and territory level (group size of 8 or $\mathrm{G}=8$ ). Because the group size is small, a conservative approach is adopted and significance levels are reported using critical values from the $\mathrm{T}(\mathrm{G}-1)$ distribution, as suggested by Cameron et al. (2008) and Cameron and Miller (2015). The conservative approach is warranted because of potential downward bias of the cluster-robust error estimates when the group size is small. Results based on wild cluster bootstrapping, a method also suggested by Cameron and Miller (2015), are presented in section 8.

\section{Estimated impacts on course choice}

While the popular media fixated on post-VTG enrolment increases in fitness instructor and other 'soft' courses with questionable career prospects, ${ }^{17}$ in reality there were enrolment increases across the board. There were indeed large increases in the number of students training to be fitness trainers, but there were also large enrolment increases in courses that prepare students for work in skill shortage occupations, such as child care workers, child care centre managers, electricians, plumbers, hairdressers and cooks (see Supplementary Appendix).

Table 3 presents estimates for constant and time-varying treatment effects (equation 1 and 2), including results under alternative counterfactual trend assumptions in the constant treatment effects case. The first two columns of estimates are not conditioned on observables and represent the overall effects of the reforms. The first column of estimates suggests that the VTG led to economically and statistically significant increases in the proportion of enrolments in courses related to skill shortage occupations of between 2.5 and 5 percentage points. The time-varying treatment effect estimates - which do not include state-specific trends - suggest the magnitude of this effect was reasonably stable over the three post-treatment years. Results are also consistent regardless of the counterfactual assumptions. 
The second column of estimates for expected graduate earnings are generally positive over the post-reform period, although the overall magnitude and significance of the effect is sensitive to the choice of counterfactual trend assumption. Under standard parallel trend assumptions, we find initially positive impacts that become negative by year 3 , with no positive effect overall. In contrast, under alternative counterfactual assumptions of linear diverging trends, we find significant positive results. Given the sensitivity of the results to counterfactual trend assumptions, we cannot be sure that the reform led to enrolments with higher expected graduate earnings on average over the post-reform period. There is also a plausible reason why the reforms may not have increased expected graduate earnings. Specifically, it is possible that increased responsiveness of enrolments associated with skill shortages in 2010 and $2011-$ a shift right in labour supply - led to lower graduate earnings in these areas and students did not update their choices accordingly. This explanation is supported by analysis presented in the Supplementary Appendix that shows that the VTG was associated with an 8 percent fall in graduate earnings within skill shortage areas in 2011 (Table A6) and that the composition of student enrolments didn't adjust accordingly (Table A7). ${ }^{18}$ Unlike for skill shortages, information on graduate earnings is not made publicly available.

Adding controls for student and provider characteristics to the model - the second and third sets of results in Table 3 - makes little difference to the estimated treatment effects under either counterfactual trend assumption. Because it is a rich set of observable student characteristics being controlled for here, with no discernible effect on the estimates, it is implausible that compositional changes in unobservables are instead driving the estimated effects. If the overall VTG impact on course choice is not being driven by compositional changes on the demand or the supply side, then we are left with differences in information accessed by students and government, differences in the weight placed on the consumptive benefits of education, and government inertia and political economy factors as potential mechanisms. If we assume that 
government is better informed regarding skill shortages at the national level and places a lower weight on the consumption benefits of education than 15-19 year old potential students, then government inertia and political economy factors are left as the most likely mechanisms to explain this positive impact of the VTG reforms on the course choice measures.

Now turn to the question of heterogeneous treatment effects. A key motivation for estimating such effects is a concern that students from disadvantaged groups may suffer (or at least benefit less than more advantaged students) from the introduction of a voucher scheme, possibly because of difficulty accessing and utilising labour market information. In fact, with a full set of controls, groups who are commonly regarded as disadvantaged do show increases in the proportion of enrolments in skill shortage areas, albeit the results are not always statistically significant. There are no groups for whom we find a significant negative impact under either counterfactual trend assumption or for either course choice measure, and none of the estimated effects for these groups are systematically larger or smaller than the baseline estimates (Table 4).

Table 4 does tentatively suggest discrepancies in course choice effects by college type, although conclusions in this respect are sensitive to the choice of counterfactual trend assumptions. These discrepancies - or more precisely the lack of discrepancies in the opposite direction - provide further evidence that the VTG did not primarily impact course choice through changes in the composition of the supply side; if anything, such compositional changes attenuated the overall VTG impact. For public colleges, the VTG drives an increase in the proportion of enrolments in skill shortage courses and an increase in expected course returns under both counterfactual assumptions whereas for private providers the picture is more mixed. Inasmuch as these estimates do show different course choice effects by college type, they are consistent with established public colleges exploiting their competitive advantages in delivering training in areas of persistent skills shortage, established over time under the 
centrally-planned system, with private providers primarily exploiting new opportunities to capture public funding in other fields of student demand less closely linked to skill shortage areas.

\section{Estimated impacts on achievement}

Table 5 presents estimates for constant and time-varying treatment effects (equation 1 and 2), again including results estimated under alternative counterfactual trend assumptions in the constant treatment effects case. For both achievement measures, all estimated constant treatment effects are positive, regardless of the counterfactual trend assumption, although they are not always statistically significant. For reasons discussed earlier, however, the following discussion focuses on module completion, for which the estimates are highly robust to the choice of counterfactual trend assumption and consistently statistically significant.

The first set of estimates for module completion are unconditional and suggest that, under standard assumptions set out in Section 5, the VTG led to significant increases in completion rates in Victoria relative to the rest of Australia. The second set of estimates is conditional on student observables. As for course choice, adding individual controls makes little difference to the estimates, suggesting that observable compositional changes on the student side are unimportant in explaining impacts on academic performance. Again, it appears implausible that compositional changes in unobservables are instead driving the estimated effects. Adding provider characteristics as controls also has little impact on the estimated treatment effects (a slight fall in the magnitude of the estimated effect, but within conventional confidence intervals in each case). The final set of results adds controls for 71 fields of study categories, five course level categories and skill demand variables (national shortage and expected earnings at the time of enrolment) to (1). These also make little difference to the estimates.

In line with the school vouchers literature, after controlling for student and college compositional changes and changes in course choices, the remaining effect is most plausibly 
interpreted as being driven by improvements in the quality of VET provision associated with increased competition between providers. The magnitude of this module completion effect is also large; of roughly the same order of magnitude as the negative impact from having a disability at the time of enrolment.

Note there is a marked delay in the onset of this positive completion effect - it is only really in the second post-reform year that the competition effect kicks in - which is consistent with administrative barriers or other sources of institutional inertia holding back change in response to the new environment on the part of incumbent providers. For example, it may take time to replace under-performing teaching staff or management.

Now consider heterogeneous effects. A concern in the school voucher literature is that any improvement in efficiency from the introduction of an untargeted voucher comes at the expense of equity because of rent-seeking responses by colleges (e.g. Levin, 1991; Ladd, 2002). Table 6 presents the estimated VTG effects for key groups and college types under both sets of counterfactual trend assumptions and with the full set of controls. As for the average estimates the focus is on the module completion results. While results in Table 5 suggest that the VTG leads to improved efficiency, measured by improvements in module achievement, results presented in Table 6 suggest no clear trade-off with equity. Significant improvements in module completion rates are observed for all of the identified groups commonly regarded as disadvantaged, and again none of the estimated effects for these groups are systematically larger or smaller than the baseline estimates.

The absence of an equity-efficiency trade-off associated with the VTG contrasts with findings in the school vouchers literature (see Epple et al., 2015). This could reflect general institutional differences between sectors: unlike school, VET colleges are open access, cater particularly for people who are not academic high fliers, and enrolment is voluntary. But there are other possible explanations specific to the design of the VET voucher, including tight 
constraints on fee increases and cream-skimming, which may have allowed the Victorian government to reap achievement-related benefits from greater competition without widespread equity-related costs.

The VTG also drives improvement in private provider and public college module completion rates, although the positive effect for public colleges is only marginally significant in one case. A positive effect among existing colleges suggests they are upping their game in response to the reforms. The parallel in the schools competition literature is the positive impacts on achievement in existing public schools - lifting all boats - reported by Hoxby $(1994 ; 2000$; 2003).

\section{Sensitivity analyses}

This section discusses sensitivity analyses that together help to reinforce the main conclusions from the preceding sections (see Table 7). Unless otherwise stated, all sensitivity results are estimated under standard trend assumptions using the full set of controls, consistent with results presented in the right-hand columns of Tables 3 and $5 .{ }^{19}$ That said, we test the sensitivity of results to other alternative counterfactual trend assumptions besides linear diverging trends, namely non-linear (quadratic). Results from these tests produce consistently positive and significant results across all measures, with $90 \%$ confidence intervals that are, in the main, overlapping with those from the standard results with full controls (from Tables 3 and 5).

Although there are few obvious culprits (and each is addressed below), the possibility of other uncontrolled-for asymmetric shocks at the state level cannot be entirely ruled out ex ante for any of the four outcome measures. This is less likely to be an issue, however, for the twin towns of Albury and Wodonga, situated on opposite banks of the Murray River on the NSWVictoria border, and which share a common labour market. Both towns have populations of around 50,000 people and both have their own public and private VET colleges, but only 
colleges in Wodonga on the Victorian side were directly affected by the VTG. Using a similar difference-in-differences approach to estimate (1) for colleges operating in the local government areas of Albury-Wodonga again shows positive and statistically significant VTG impacts on all outcome measures, although the estimated magnitudes of these impacts differ (based on non-overlapping confidence intervals) from those estimated at the full state level. The relatively large impact on enrolments in skill-shortage areas may reflect the inability of the former centralised funding model to respond to the specific needs of local labour markets. ${ }^{20}$

One possible candidate for an asymmetric state-level shock is the introduction of national requirements to be in study (school or VET) until age 17 in 2010, which may have had differing effects in the rest of Australia and Victoria because prior compulsory education ages were different across states. Most importantly, compulsory education leaving age in NSW, the most populous state, was 15 prior to the reform, compared to 16 in Victoria. Results in Table 7 show that restricting the sample to those who enrolled at 18 and 19 , and who were therefore unaffected by the national education requirement, increases the magnitude of the positive effects. The reason for the stronger results without those aged 17 or under is that the introduction of the national education requirement reduced the number of 15 and 16 year-olds in VET in the rest of Australia relative to Victoria from 2010. Because young people who leave school at this age tend to make relatively poor course choices and perform relatively poorly, the reform tended to improve outcomes in the rest of Australia relative to Victoria, biasing the estimated effects of the VTG downwards. These suggest that our results are conservative.

Other specific sources of potential asymmetric shocks are anticipation effects that may have occurred in Victoria post-announcement but pre-reform; post-reform effects that occurred in the second half of 2009; and the introduction of the South Australian voucher in July 2012. Responses that may have occurred prior to the commencement of the post-reform period are examined by re-estimating all models without enrolments from the time of announcement 
(August 2008) to the end of 2009. This restriction does not impact on the estimated magnitude of the VTG impacts, but does reduce precision. Asymmetric shocks to the rest of Australia from the introduction of the South Australian voucher are examined by re-estimating without enrolments from July 2012. Results are much the same as without their exclusion.

To examine whether college and course controls are adequate to deal with compositional changes associated with the VTG, the models for course choice are re-estimated with college fixed effects, and the models for achievement are re-estimated with college and course fixed effects. This makes little difference to the estimated VTG impacts, although adding college fixed effects does increase the magnitude of course choice outcomes to the point that the positive estimated effect for expected returns is on the cusp of statistical significance at $10 \%$. This is likely to reflect disproportionate growth in the private colleges that specialise in courses that are unrelated to skill shortages. Conclusions remain unchanged.

The sensitivity of the results to decisions regarding the sample is also tested. First, note that fee-for-service enrolments with public colleges that are not covered by the VTG, but which may be displaced by the VTG, are included in the analysis thus far. Results estimated with such enrolments excluded are reported in Table 7. Second, when estimating outcomes using the skill shortage measure, enrolments that are not associated with a specific occupation are omitted. The estimates are therefore for a smaller sample than those for the earnings-based measure. To test the effect of differences in the sample, the model for expected earnings is re-estimated on the same sample used for skill shortages. Third, for the field of study/course level combinations for which insufficient observations in the SOS are observed to confidently estimate an average wage premium, estimates are generated from more aggregated field of study/course level combinations. Alternatively enrolments in these courses can be dropped from the estimation of the wage-based measure of course choice. Results from using each of these alternative samples are much the same as the standard results reported in Tables 3 and 5. 
Finally, in the models estimated thus far, inference has been based on cluster-robust standard errors using conservative T(G-1) critical values (Cameron et al., 2008 and Cameron and Miller, 2015). Despite the conservative approach, however, it is still possible to over-reject the null hypotheses of no significant effects (Cameron and Miller, 2015). Robustness is tested following Cameron and Miller's (2015) suggestion by re-estimating the significance levels of the main results (with full controls) using wild cluster bootstrapping with 1000 iterations. This method has been shown to perform well in simulation studies, including when the group size is less than 10 (Cameron et al., 2008). The p-values estimated from the bootstrapping are all significant at the $10 \%$ mark and suggest that inference based on cluster-robust standard errors and $\mathrm{T}(\mathrm{G}-1)$ critical values is not leading to over-rejection of the null in this case.

\section{Conclusions}

This paper exploits a unique natural experiment in Australia to demonstrate for the first time that introducing a system-wide voucher scheme can improve the relevance and quality of postsecondary VET. Further, by varying controls, conclusions are drawn regarding possible causal mechanisms. The key question that remains is the extent to which these conclusions might generalise to VET elsewhere and to other parts of the education sector.

For course choice, the positive treatment effect shows that linking funding to student choices, rather than centralised government allocations, led to a better alignment of enrolments with skill demands, as defined by enrolments that prepare students for jobs on national skill shortage lists. For employers, the improved enrolment responsiveness to skill shortages reduced the cost of employing new graduates in these occupations. However, the extent to which students responded to changes in course graduate earnings, an alternative signal of skill demand, is unclear because the significance and magnitude of the results depend on the underlying counterfactual trend assumption. The weaker student response to the latest course graduate earnings compared to the latest skill shortages, regardless of the trend assumption, is 
not surprising given that information on the former is not publicly available. This result underlines the need for the public release of up-to-date information on course-specific returns to complement government skill shortage information.

Whilst there is no guarantee that the same positive course choice impacts would be replicated elsewhere - these may have been unusually well-informed students, or the Victorian government at the time may have made unusually poor allocation decisions pre-reform - the fact that other Australian states and other English-speaking countries with shared VET-sector characteristics also share dissatisfaction with existing funding models on the grounds of training relevance suggests Victoria is not uniquely able to benefit from a broad-based VET voucher, particularly where students are also given access to relevant information on coursespecific returns.

The paper also shows that membership of a disadvantaged group does not affect one's ability to benefit from greater agency to select preferred post-secondary courses afforded under a voucher. This contrasts with literature that suggests students from disadvantaged groups benefit less from school choice reforms because of an inability to access and assess school performance information (Levin, 1991; Ladd, 2002; Hastings and Weinstein, 2008). One explanation is that when choosing post-secondary VET courses, students from disadvantaged groups may be less encumbered by resource constraints and parental attitudes, and may link course choice more closely to their future job prospects than when choosing schools. It may also be that labour market information is more equally available (or unavailable) than information on school quality. The extent to which this particular conclusion might generalise beyond Australian VET is unclear, but we at least have new evidence that leads us to question the extent to which the earlier conclusions regarding the equity costs of school choice reforms generalise to other educational contexts. 
For achievement, increased competition between providers is the channel most consistent with the estimated positive reform impacts, which are observed across both new private providers and incumbent public providers; competition raises all VET boats. A further contribution of the paper is to demonstrate that these achievement gains, like the course choice gains, do not come at a cost to equity; in contrast to findings by Hsieh and Urquiola (2006) and others, this paper shows that under conditions where there is little student selection, academic achievement gains are widespread, including among disadvantaged groups. To the extent that this reflects potentially replicable regulations that constrain cream-skimming and fee caps, then the findings highlight the potential role of such safeguards in realising the competition benefits of broad-based vouchers without the equity costs.

There are of course many caveats to bear in mind when drawing these conclusions. It is possible that students make better course choices according to the two measures here, but would not do so according to some alternative measure forecasting ahead to future labour market needs, where governments plausibly have a greater informational advantage. It is also possible that the improvements in student achievement reflect a form of grade inflation (or more precisely competency inflation) rather than any real improvement in skills, given that across Australia (and in other countries) it is the colleges themselves that are responsible for assessment. (This would in itself be an interesting result, but not necessarily one that governments would want to replicate). If nothing else, however, the regime in place for external moderation of assessments, coupled with the fact that course-level completion data were not made systematically available at the time, make us question this as an explanation. Third, the conclusions are based on just three post-reform cohorts, each followed for a maximum of two years, and there is reason to suspect - from the estimates presented here and from the wider literature - that the early impacts of such reforms may differ from longer run impacts. 
The narrative around these reforms turned rapidly negative in Victoria in the absence of credible evidence on their impacts at the time and given the budgetary implications of the rapid growth in enrolment. This led to the partial roll-back of the reforms in July 2012, which this paper shows may have been a mistake. Looking forward, this paper can potentially support governments to design, implement and sustain wholesale changes, perhaps against the wishes of incumbent providers and in the face of hostile media coverage. 


\section{References}

Australian Bureau of Statistics (ABS) (2016). Schools Australia 2015, ABS catalogue no. 4221.0, ABS, Canberra.

Avery, C. and Turner, S. (2012). Student loans: do college students borrow too much--or not enough? Journal of Economic Perspectives, 26, 1, 165-92.

Baker, R., Bettinger, E., Jacob, B. and Escu, MI. (2017). The effect of labor market information on community college students' major choice. NBER Working Paper 23333. Cambridge MA: National Bureau of Economic Research.

Bettinger, E., Kremer, M., Saavedra, J.E. (2010). Are educational vouchers only redistributive? Economic Journal 120, 546: F204-F228.

Blochliger, H. (2008). Market mechanisms in public service provision. OECD Economics Department Working Papers 626, Paris: OECD.

Blundell, R. and Costa Dias, M. (2009). Alternative approaches to evaluation in empirical microeconomics. Journal of Human Resources 44, 3, 565-640.

Böhlmark, A. and Lindahl, M. (2015). Independent schools and long-run educational outcomes: evidence from Sweden's large-scale voucher reform. Economica 82, 327: 508-551.

Bound, J. and Turner, S. (2011). Dropouts and diplomas: the divergence in collegiate outcomes. In E.A. Hanushek, S. Machin and L.Woessmannn (eds.) Handbook of Economics of Education Volume 4, Amsterdam: Elsevier North-Holland.

Cameron, A.C., Gelbach, J.B. and Miller, D.L., (2008). Bootstrap-based improvements for inference with clustered errors. The Review of Economics and Statistics, 90, 3, 414-427. 
Cameron, A.C. and Miller, D.L., (2015). A practitioner's guide to cluster-robust inference. Journal of Human Resources 50, 2, 317-372.

Cameron, R. (2011). Responding to Australia's regional skill shortages through regional skilled migration, Journal of Economic and Social Policy 14(3), 1-33.

Demming, D.J., Goldin, C. anhd Katz, L.F. (2012). The for-profit postsecondary school sector: nimble critters or agile predators? Journal of Economic Perspectives 26, 1, 139-164.

Epple, D., Romano, R.E. and Urquiola, M. (2015). School vouchers: a survey of the economics literature. NBER Working Paper 21523. Cambridge MA: National Bureau of Economic Research.

Figlio, D. and Hart, C. (2014). Competitive effects of means-tested school vouchers. American Economic Journal: Applied Economics 6, 1: 133-156.

Friedman, M. (1962). Capitalism and Freedom, London: Chicago University Press.

Groen, J.A. and Polivka, A.E., (2008). The effect of Hurricane Katrina on the labor market outcomes of evacuees. The American Economic Review, 98, 2,43-48.

Grogger, J. and Eide, E. (1995). Changes in college skills and the rise in the college wage premium. Journal of Human Resources 30, 2, 280-310.

Hastings, J.S. and Weinstein, J.M. (2008). Information, School Choice, and Academic Achievement: Evidence from Two Experiments. Quarterly Journal of Economics 123, 4, 1373414. 
Heckman, J.J., Lochner, L.J. and Todd, P.E. (2006). Earnings functions, rates of return and treatment effects: the Mincer equation and beyond. In E.A. Hanushek and F. Welch (eds.) Handbook of the Economics of Education Volume 1, Amsterdam: North Holland.

Hidalgo, D., Oosterbeek, H. and Webbink, D. (2014). The impact of training vouchers on lowskilled workers. Labour Economics 31: 117-128.

Hoxby, C.M. (1994). Do private schools provide competition for public schools? NBER Working Paper no. 4978. Cambridge MA: National Bureau of Economic Research.

Hoxby, C.M. (2000). Does competition among public schools benefit students and taxpayers? American Economic Review 90, 5, 1209-1238.

Hoxby, C.M. (2003). School choice and school productivity: could school choice be a tide that lifts all boats? In C.M. Hoxby (ed.) The Economics of School Choice, Chicago: University of Chicago Press.

Hsieh, C.-T. and Urquiola, M. (2006). Th effects of generalized school choice on achievement and stratification: evidence from Chile's voucher program. Journal of Public Economics 90, $1477-1503$.

Jayachandran, S., Lleras-Muney, A. and Smith, K.V., (2010). Modern medicine and the twentieth century decline in mortality: evidence on the impact of sulfa drugs. American Economic Journal: Applied Economics, 2, 2,118-146.

Jensen, R. (2010). The (perceived) returns to education and the demand for schooling. Quarterly Journal of Economics 125, 2, 515-48.

Ladd, H.F. (2002). School vouchers: a critical view. Journal of Economic Perspectives 16, 4, 3-24. 
Lavy, V. (2006). From forced busing to free choice in public schools: quasi-experimental evidence of individual and general effects. NBER Working Paper no.11969. National Bureau of Economic Research, Cambridge MA.

Levin, H.M. (1991). The economics of educational choice. Economics of Education Review $10,2,137-158$.

Mark, K. and Karmel, T. (2010) 'The likelihood of completion a VET qualification: A modelbased approach.’ NCVER, Adelaide.

OECD (2010). 'Learning for jobs: synthesis of the OECD reviews of vocational education and training', OECD, Paris.

OECD (2014). 'Skills beyond school: synthesis report', OECD, Paris.

Oreopoulos, P. and Salvanes, K.G. (2011). Priceless: the non-pecuniary benefits of schooling. Journal of Economic Perspectives 25, 1, 159-84.

Polidano, C. and Ryan, C. (2016). What happens to students with low reading proficiency at 15? Evidence from Australia, Melbourne Institute of Applied Economic and Social Research Working Paper 33.16, University of Melbourne, Melbourne.

Rosenbaum, J.E. and Rosenbaum, J. (2013). Beyond BA blinders: lessons from Occupational Colleges and Certificate Programs for nontraditional students. Journal of Economic Perspectives 27, 2, 153-172.

Ryoo, L. and Rosen, S. (2004). 'The engineering labor market.' Journal of Political Economy, 112, S110-S140. 
Schwerdt, G., Messer, D., Woessmann, L. and Wolter, S.C. (2012). The impact of an adult education voucher program evidence from a randomized field experiment. Journal of Public Economics 96, 569-583.

Stevens, M. (1999). Human capital theory and UK vocational training policy, Oxford Review of Economic Policy 15(1), 16-32.

U.S. Department of Education (2012). Investing in America's Future: A Blueprint for Transforming Career and Technical Education, Washington, D.C.: Office of Vocational and Adult Education, US Department of Education.

Wolf, A. (2011). Review of Vocational Education - The Wolf Report, Department of Education, United Kingdom. 
Table 1: New post-secondary VET course enrolments of 15-19 year olds

\begin{tabular}{|c|c|c|c|c|c|c|}
\hline & \multicolumn{3}{|l|}{ Victoria } & \multicolumn{3}{|c|}{ Rest of Australia } \\
\hline & $\begin{array}{l}\text { Public } \\
\text { college }\end{array}$ & $\begin{array}{l}\text { Private } \\
\text { college }\end{array}$ & Total & $\begin{array}{l}\text { Public } \\
\text { college }\end{array}$ & $\begin{array}{l}\text { Private } \\
\text { college }\end{array}$ & Total \\
\hline 2006 & 52,861 & 9,454 & 62,315 & 130,722 & 22,267 & 152,989 \\
\hline 2007 & 53,218 & 8,304 & 61,522 & 133,225 & 21,752 & 154,977 \\
\hline 2008 & 53,774 & 6,811 & 60,585 & 118,351 & 23,650 & 142,001 \\
\hline 2009 & 54,773 & 7,406 & 62,179 & 130,233 & 30,485 & 160,718 \\
\hline 2010 & 60,711 & 16,766 & 77,477 & 127,716 & 36,233 & 163,949 \\
\hline 2011 & 58,667 & 30,632 & 89,299 & 126,736 & 39,266 & 166,002 \\
\hline 2012 & 82,411 & 33,604 & 116,015 & 129,976 & 35,191 & 165,167 \\
\hline Avg. annual 2006-09 & 53,657 & 7,994 & 61,650 & 128,133 & 24,539 & 152,671 \\
\hline Avg. annual 2010-12 & 67,263 & 27,001 & 94,264 & 128,143 & 36,897 & 165,039 \\
\hline Difference & 13,607 & 19,007 & 32,613 & 10 & 12,358 & 12,368 \\
\hline
\end{tabular}

Note: Public colleges include Technical and Further Education (TAFE) colleges, Adult and Community Education (ACE) colleges and Universities. Private colleges include professional/industry organisations, other non-government organisations and for-profit training colleges. These estimates exclude enrolments among those who are still in secondary school. 
Table 2: Mean characteristics of 15-19 year-old new post-secondary VET course enrolments, pre and post reform

\begin{tabular}{|c|c|c|c|c|}
\hline & \multicolumn{2}{|l|}{ Victoria } & \multicolumn{2}{|c|}{ Rest of Australia } \\
\hline & $2006-09$ & 2010-12 & 2006-09 & $2010-12$ \\
\hline \multicolumn{5}{|l|}{ Outcomes } \\
\hline National Skill Shortage enrolments (\%) & 18.3 & 13.0 & 22.8 & 15.1 \\
\hline Expected graduate earnings (log earnings, $\$ A 2013)^{a}$ & -0.13 & -0.11 & -0.11 & -0.09 \\
\hline Course completion $(\%)$ & 23.2 & 29.5 & 28.8 & 31.5 \\
\hline Module completion (\%) & 73.3 & 78.3 & 76.3 & 76.6 \\
\hline \multicolumn{5}{|l|}{ Controls } \\
\hline \multicolumn{5}{|l|}{ State $(\%)$} \\
\hline Victoria & 100 & 100 & & \\
\hline NSW & - & - & 41.1 & 39.2 \\
\hline Queensland & - & - & 26.2 & 27.3 \\
\hline Western Australia & - & - & 15.2 & 16.3 \\
\hline South Australia & - & - & 9.8 & 10.6 \\
\hline Tasmania & - & - & 4.2 & 3.9 \\
\hline Australian Capital Territory & - & - & 2.1 & 1.5 \\
\hline Northern Territory & - & - & 1.4 & 1.2 \\
\hline \multicolumn{5}{|l|}{ Year of course commencement $(\%)$} \\
\hline 2006 & 25.3 & 0 & 25.1 & 0 \\
\hline 2007 & 24.9 & 0 & 25.4 & 0 \\
\hline 2008 & 24.6 & 0 & 23.3 & 0 \\
\hline 2009 & 25.2 & 0 & 26.3 & 0 \\
\hline 2010 & 0 & 27.4 & 0 & 33.1 \\
\hline 2011 & 0 & 31.6 & 0 & 33.5 \\
\hline 2012 & 0 & 41 & 0 & 33.4 \\
\hline \multicolumn{5}{|l|}{ Month of course commencement $(\%)$} \\
\hline January & 25.6 & 10.8 & 10.5 & 8.6 \\
\hline February & 37.4 & 33.3 & 42.7 & 37.6 \\
\hline March & 4 & 7.3 & 6.1 & 7 \\
\hline April & 3.6 & 5.8 & 4.1 & 4.5 \\
\hline May & 3.2 & 5.9 & 4 & 4.9 \\
\hline June & 2.7 & 7.2 & 3.1 & 3.6 \\
\hline July & 13.9 & 11.3 & 17.9 & 19.7 \\
\hline August & 3 & 5.3 & 3.7 & 4.8 \\
\hline September & 1.9 & 4 & 2.6 & 2.9 \\
\hline October & 2.6 & 4.3 & 2.6 & 3.2 \\
\hline November & 1.4 & 3.5 & 1.9 & 2.3 \\
\hline December & 0.7 & 1.3 & 0.8 & 0.9 \\
\hline Interstate residential address $(\%)^{\mathrm{b}}$ & 2.7 & 2 & 1.7 & 1.8 \\
\hline
\end{tabular}


Residential unemployment rate (local government area $\%)^{\mathrm{c}}$

Student characteristics ${ }^{\mathrm{d}}$

Student is female (\%)

Age in years on January 1 in the year of enrolment (\%)

15

16

17

18

19

Aboriginal or Torres Strait Islander (\%)

Migrant status and language spoken at home

Doesn't speaks a language other than English at home, Australian born

Speaks a language other than English at home,

Australian born

Doesn't speak a language other than English at home,

\section{foreign born}

Speaks a language other than English at home, foreign born

$$
7.3
$$

4.9

8.1

7.4

20.8

10.5

15.1

14.4

35

20.2

26.2

26.3

24.5

36.5

29.1

29.4

6

27.9

21.6

22.6

3.6

15.7

16.3

$\begin{array}{llll}50.4 & 59.2 & 56.3 & 67.5\end{array}$

2.3

3.3

3.1

4.2

32.8

28.2

26.5

17.2

9.5

8.2

6.9

5

Regional classification of residence (\%)

Major city

68.7

72.7

64.7

63.4

Inner regional

25.8

22.5

20.8

21.6

Outer regional

5.4

4.7

11.3

11.9

Remote

0.1

0.1

2.1

2

Very remote

Employed at time of enrolment (\%)

0

0

1.1

1.1

58.1

56.2

58.5

52.1

6.6

7.6

5.6

6.9

Socio-economic status of residential area $(\%)$

1st quintile (most disadvantaged nationally)

2nd quintile

4.3

$$
4.2
$$

11.5

11.9

3rd quintile

18

16.9

18.4

4 th quintile

5th quintile (most advantaged nationally)

Highest prior level of education completed (\%)

Tertiary education (ISCED 4B and above)

\section{College characteristics ${ }^{\mathrm{d}}$}

Number of enrolments in 2008 (\%)

$$
\begin{aligned}
& \text { Provider didn't exist } \\
& <100 \text { enrolments } \\
& 100-999 \text { enrolments } \\
& 1000-3999 \text { enrolments }
\end{aligned}
$$


4000-6999 enrolments

7000+ enrolments

Type of college $(\%)$

Public Technical and Further Education (TAFE)

Public Adult Centre for Education (ACE)

Public University

Private industry, professional association or nongovernment organisation

Private for profit

Private other

Course characteristics ${ }^{\mathrm{d}}$

Course qualification level (\%)

Certificate of attainment

Certificate I

Certificate II

Certificate III

Certificate IV

Diploma+

Field of study (ASCED 2-digit, \%) ${ }^{\mathrm{e}}$

Natural and physical science

Information technology

Engineering and related technology

Architecture and building

Agriculture, environment and related

Health

Education

Management and commerce

Society and culture

Creative arts

Food, hospitality and personal services

Mixed programs/general courses ${ }^{\mathrm{f}}$

National skill shortage ${ }^{g}$

Expected graduate earnings (log earnings, \$A2013) ${ }^{\mathrm{h}}$
39.9

32.5

31.2

8

6.2

22.5

18.2

$\begin{array}{llll}71.7 & 57.4 & 80.5 & 74.5 \\ 7.4 & 7.7 & 3.3 & 3.1 \\ 8 & 6.2 & 0.1 & 0.1 \\ 5.5 & 6 & 3.7 & 3.6 \\ 6.6 & 22.1 & 9.9 & 13.6 \\ 0.9 & 0.5 & 2.5 & 5.1\end{array}$

3.1

0.1

5.1

$\begin{array}{lllll}\text { Count } & 246,601 & 282,791 & 610,685 & 495,118\end{array}$

0.2

8.3

26.4

35.3

12

17.8

0.5

3.4

17

9.7

3.6

2.8

0.2

25.3

8.5

4.3

15.1

9.6

16.5

$-0.13$
1.8

11.4

24.7

37.8

12

12.4

0.3

0.4

3.9

20.2

14.2

8.9

2.7

3.8

2.4

3.1

0.2

0.7

23.7

22.2

9.7

11.4

4.5

14.1

14.3

7.7

15.7

10.8

21.1

$-0.11$

$-0.11$

$246,601 \quad 282,791$
13.4

1.9

7.9

25.9

44.2

11.5

8.5

0.4

3.4

19.3

10.5

4

3.1

0.6

20.9

10.7

4.8

12.7

9.6

$-0.09$ estimates exclude enrolments among those who are still in secondary school. This data includes information on multiple enrolments by the same individuals within a given year.

a This is relative to estimated earnings from graduates in certificate III Building, a qualification undertaken as part of a building apprenticeship. ' Identified as people whose state of residential address is different to their state in which they enrolled in study. ${ }^{\circ}$ Local government area is the geographic boundary of municipal governments similar to a county. The data is published by the Australian Department of Employment. ${ }^{\mathrm{d}}$ For more information on the definition of these variables, see Table A1 of supplementary appendix. ' Information on field of study is presented in this table at a more aggregate level (2-digit Australian Standard Classification of Education (ASCED)) than is used in the analysis (4-digit ASCED) to save space. ${ }^{\mathrm{f}}$ General courses are ones that are not preparation for a specific occupation, such as numeracy and literacy courses and employment skills training. ${ }^{\mathrm{g}}$ Binary indicator for whether course of enrolment is associated with preparation for work in an occupation that is on the national skill shortage list at the start of the year of enrolment. When used as a control in course completion models, mixed field and general courses that do not prepare students for a particular course are coded $0 .{ }^{\mathrm{h}}$ Only used as a control in course completion models. 
Table 3: Difference-in-differences coefficient estimates for course choice, 2010-12

\begin{tabular}{|c|c|c|c|c|c|c|}
\hline & \multicolumn{2}{|c|}{ Unconditional } & \multicolumn{2}{|c|}{ With individual controls } & \multicolumn{2}{|c|}{ With individual and provider controls } \\
\hline & $\begin{array}{l}\text { National skill } \\
\text { shortage }\end{array}$ & $\begin{array}{l}\text { Expected } \\
\text { graduate earnings }\end{array}$ & $\begin{array}{l}\text { National skill } \\
\text { shortage }\end{array}$ & $\begin{array}{l}\text { Expected } \\
\text { graduate earnings }\end{array}$ & $\begin{array}{l}\text { National skill } \\
\text { shortage }\end{array}$ & $\begin{array}{l}\text { Expected } \\
\text { graduate earnings }\end{array}$ \\
\hline \multicolumn{7}{|l|}{ Standard counterfactual assumptions ${ }^{\mathrm{a}}$} \\
\hline Constant treatment effect (2010-12) & $\begin{array}{l}0.025 * * * \\
(0.006)\end{array}$ & $\begin{array}{l}0.003 \\
(0.006)\end{array}$ & $\begin{array}{l}0.023 * * * \\
(0.003)\end{array}$ & $\begin{array}{l}0.006 \\
(0.005)\end{array}$ & $\begin{array}{l}0.021 * * \\
(0.007)\end{array}$ & $\begin{array}{l}0.004 \\
(0.006)\end{array}$ \\
\hline \multicolumn{7}{|l|}{ Time-varying treatment effect } \\
\hline 2010 & $\begin{array}{l}0.030 * * * \\
(0.006)\end{array}$ & $\begin{array}{l}0.017 * * \\
(0.007)\end{array}$ & $\begin{array}{l}0.025^{* * *} \\
(0.005)\end{array}$ & $\begin{array}{l}0.018 * * \\
(0.007)\end{array}$ & $\begin{array}{l}0.023 * * \\
(0.007)\end{array}$ & $\begin{array}{l}0.017 * * \\
(0.007)\end{array}$ \\
\hline 2011 & $\begin{array}{l}0.020 * * \\
(0.007)\end{array}$ & $\begin{array}{l}0.022 * \\
(0.010)\end{array}$ & $\begin{array}{l}0.022 * * * \\
(0.005)\end{array}$ & $\begin{array}{l}0.027 * * \\
(0.010)\end{array}$ & $\begin{array}{l}0.021 * * \\
(0.009)\end{array}$ & $\begin{array}{l}0.024 * \\
(0.011)\end{array}$ \\
\hline 2012 & $\begin{array}{l}0.025^{* *} \\
(0.008)\end{array}$ & $\begin{array}{l}-0.024 * * * \\
(0.005)\end{array}$ & $\begin{array}{l}0.022 * * \\
(0.007)\end{array}$ & $\begin{array}{l}-0.021 * * * \\
(0.005)\end{array}$ & $\begin{array}{l}0.020 * * \\
(0.008)\end{array}$ & $\begin{array}{l}-0.023 * * * \\
(0.006)\end{array}$ \\
\hline \multicolumn{7}{|l|}{ Alternative counterfactual assumptions ${ }^{b}$} \\
\hline Constant treatment effect (2010-12) & $\begin{array}{l}0.050 * * \\
(0.015)\end{array}$ & $\begin{array}{l}0.033 * * * \\
(0.009)\end{array}$ & $\begin{array}{l}0.044 * * \\
(0.014)\end{array}$ & $\begin{array}{l}0.035^{* * *} \\
(0.008)\end{array}$ & $\begin{array}{l}0.047 * * * \\
(0.013)\end{array}$ & $\begin{array}{l}0.033 * * * \\
(0.008)\end{array}$ \\
\hline Count & $1,462,223$ & $1,596,394$ & $1,457,328$ & $1,591,001$ & $1,456,904$ & $1,590,552$ \\
\hline
\end{tabular}

*** Significant at 1\%,**significant at 5\% and *significant at 10\%. Standard errors are robust-clustered at the state and territory level with critical values based on T(8-1) distribution. All models are estimate

available information. The sample size for results using the National Skill Shortage measure are smaller because we exclude enrolments in general courses that do not prepare people for any specific course.

${ }^{a}$ Counterfactual outcomes in Victoria are assumed to follow a parallel path to those of the Rest of Australia. ${ }^{\text {b} C o u n t e r f a c t u a l ~ o u t c o m e s ~ i n ~ V i c t o r i a ~ a r e ~ a s s u m e d ~ t o ~ d i v e r g e ~ r e l a t i v e ~ t o ~ t h e ~ R e s t ~ o f ~ A u s t r a l i a ~ a t ~ t h e ~ s a m e ~}$

constant rate present prior to the reform (2006-09). 
Table 4: Heterogeneous difference-in-differences coefficient estimates for course choice, 2010-12, constant treatment effects with individual and course controls

\begin{tabular}{|c|c|c|c|c|}
\hline Sub-sample & \multicolumn{2}{|c|}{$\begin{array}{c}\text { Standard counterfactual assumptions }{ }^{\mathrm{a}} \\
\text { Expected }\end{array}$} & $\begin{array}{r}\text { Alternati } \\
\text { Skill shortage } \\
\end{array}$ & $\begin{array}{l}\text { erfactual assumptions } \\
\text { Expected } \\
\text { graduate earnings }\end{array}$ \\
\hline \multirow[t]{2}{*}{ Female } & 0.003 & 0.006 & $0.026 * *$ & $0.034 * *$ \\
\hline & $(0.007)$ & $(0.006)$ & $(0.011)$ & $(0.010)$ \\
\hline \multirow[t]{2}{*}{ Disability } & $0.025^{*}$ & $0.026 * *$ & $0.036 * * *$ & $0.045^{* *}$ \\
\hline & $(0.012)$ & $(0.011)$ & $(0.008)$ & $(0.014)$ \\
\hline \multirow[t]{2}{*}{ Speaks a language other than English at home } & $0.039 * *$ & 0.009 & $0.040 * *$ & $0.039 * *$ \\
\hline & $(0.015)$ & $(0.008)$ & $(0.016)$ & $(0.012)$ \\
\hline \multirow[t]{2}{*}{$\begin{array}{l}\text { Reside in a suburb whose socio-economic status (SEIFA) is in the } \\
\text { lowest quintile nationally }\end{array}$} & $0.038^{*}$ & -0.008 & 0.026 & -0.000 \\
\hline & $(0.016)$ & $(0.013)$ & $(0.024)$ & $(0.014)$ \\
\hline \multirow[t]{2}{*}{ Lives outside a capital city } & $0.017^{*}$ & -0.005 & $0.033 *$ & 0.019 \\
\hline & $(0.008)$ & $(0.006)$ & $(0.015)$ & $(0.013)$ \\
\hline \multirow[t]{2}{*}{ Less than secondary school qualification } & 0.008 & -0.006 & $0.033 * *$ & $0.033 * * *$ \\
\hline & $(0.009)$ & $(0.008)$ & $(0.012)$ & $(0.009)$ \\
\hline \multirow[t]{2}{*}{ Unemployed } & $0.025 * * *$ & -0.000 & $0.049 * * *$ & $0.043 * * *$ \\
\hline & $(0.004)$ & $(0.009)$ & $(0.007)$ & $(0.010)$ \\
\hline \multirow[t]{2}{*}{ Public college } & $0.044 * * *$ & 0.015 & $0.048 * * *$ & $0.045^{* * *}$ \\
\hline & $(0.006)$ & $(0.008)$ & $(0.008)$ & $(0.009)$ \\
\hline \multirow[t]{2}{*}{ Private for profit college } & -0.037 & 0.006 & 0.047 & $0.038 * * *$ \\
\hline & $(0.051)$ & $(0.005)$ & $(0.103)$ & $(0.007)$ \\
\hline \multirow[t]{2}{*}{ Overall } & $0.025 * * *$ & 0.003 & $0.047 * * *$ & $0.033 * * *$ \\
\hline & $(0.006)$ & $(0.006)$ & $(0.013)$ & $(0.008)$ \\
\hline
\end{tabular}


Table 5: Difference-in-differences coefficient estimates for course completion, 2010-2012

\begin{tabular}{|c|c|c|c|c|c|c|c|c|}
\hline & \multicolumn{2}{|c|}{ Unconditional } & \multicolumn{2}{|c|}{ With individual controls } & \multicolumn{2}{|c|}{$\begin{array}{c}\text { With individual and provider } \\
\text { controls }\end{array}$} & \multicolumn{2}{|c|}{$\begin{array}{c}\text { With individual, provider and } \\
\text { course controls }\end{array}$} \\
\hline & $\begin{array}{l}\text { Module } \\
\text { completion }\end{array}$ & $\begin{array}{l}\text { Course } \\
\text { completion } \\
\end{array}$ & $\begin{array}{l}\text { Module } \\
\text { completion }\end{array}$ & $\begin{array}{l}\text { Course } \\
\text { completion }\end{array}$ & $\begin{array}{l}\text { Module } \\
\text { completion } \\
\end{array}$ & $\begin{array}{l}\text { Course } \\
\text { completion }\end{array}$ & $\begin{array}{l}\text { Module } \\
\text { completion } \\
\end{array}$ & $\begin{array}{l}\text { Course } \\
\text { completion } \\
\end{array}$ \\
\hline \multicolumn{9}{|l|}{ Standard counterfactual assumptions ${ }^{\mathrm{a}}$} \\
\hline Constant treatment effect (2010-12) & $\begin{array}{l}0.034 * * * \\
(0.009)\end{array}$ & $\begin{array}{l}0.038 * \\
(0.019)\end{array}$ & $\begin{array}{l}0.031 * * \\
(0.011)\end{array}$ & $\begin{array}{l}0.029 \\
(0.020)\end{array}$ & $\begin{array}{l}0.022 * * \\
(0.009)\end{array}$ & $\begin{array}{l}0.01 \\
(0.017)\end{array}$ & $\begin{array}{l}0.031 * * * \\
(0.008)\end{array}$ & $\begin{array}{l}0.011 \\
(0.011)\end{array}$ \\
\hline \multicolumn{9}{|l|}{ Time-varying treatment effect } \\
\hline 2010 & $\begin{array}{l}0.020 * \\
(0.009)\end{array}$ & $\begin{array}{l}0.017 \\
(0.020)\end{array}$ & $\begin{array}{l}0.014 \\
(0.010)\end{array}$ & $\begin{array}{l}0.011 \\
(0.021)\end{array}$ & $\begin{array}{l}0.011 \\
(0.008)\end{array}$ & $\begin{array}{l}0.002 \\
(0.017)\end{array}$ & $\begin{array}{l}0.011 \\
(0.008)\end{array}$ & $\begin{array}{l}0.000 \\
(0.014)\end{array}$ \\
\hline 2011 & $\begin{array}{l}0.036 * * * \\
(0.010)\end{array}$ & $\begin{array}{l}0.050 * \\
(0.023)\end{array}$ & $\begin{array}{l}0.036 * * \\
(0.013)\end{array}$ & $\begin{array}{l}0.039 \\
(0.024)\end{array}$ & $\begin{array}{l}0.022 * \\
(0.010)\end{array}$ & $\begin{array}{l}0.009 \\
(0.021)\end{array}$ & $\begin{array}{l}0.035 * * * \\
(0.009)\end{array}$ & $\begin{array}{l}0.008 \\
(0.016)\end{array}$ \\
\hline 2012 & $\begin{array}{l}0.043 * * * \\
(0.010)\end{array}$ & $\begin{array}{l}0.044 * * \\
(0.016)\end{array}$ & $\begin{array}{l}0.040 * * * \\
(0.011)\end{array}$ & $\begin{array}{l}0.035^{*} \\
(0.017)\end{array}$ & $\begin{array}{l}0.031 * * \\
(0.009)\end{array}$ & $\begin{array}{l}0.016 \\
(0.014)\end{array}$ & $\begin{array}{l}0.042 * * * \\
(0.009)\end{array}$ & $\begin{array}{l}0.025^{* *} \\
(0.009)\end{array}$ \\
\hline \multicolumn{9}{|l|}{ Alternative counterfactual assumptions ${ }^{\mathrm{b}}$} \\
\hline Constant treatment effect (2010-12) & $\begin{array}{l}0.039 * * * \\
(0.005)\end{array}$ & $\begin{array}{l}0.067 * * * \\
(0.012)\end{array}$ & $\begin{array}{l}0.031 * * * \\
(0.005)\end{array}$ & $\begin{array}{l}0.061 * * * \\
(0.010)\end{array}$ & $\begin{array}{l}0.021 * * \\
(0.008)\end{array}$ & $\begin{array}{l}0.040 * * * \\
(0.011)\end{array}$ & $\begin{array}{l}0.026 * * * \\
(0.007)\end{array}$ & $\begin{array}{l}0.041 * * * \\
(0.010)\end{array}$ \\
\hline Count & $1,596,937$ & $1,635,195$ & $1,591,528$ & $1,629,707$ & $1,591,080$ & $1,629,237$ & $1,591,080$ & $1,629,237$ \\
\hline
\end{tabular}


Table 6: Heterogeneous difference-in-differences coefficient estimates for course completion, 2010-2012, constant treatment effects with individual, provider and course controls

\begin{tabular}{|c|c|c|c|c|}
\hline \multirow[t]{2}{*}{ Sub-sample } & \multicolumn{2}{|c|}{ Standard counterfactual assumptions ${ }^{\mathrm{a}}$} & \multicolumn{2}{|c|}{ Alternative counterfactual assumptions ${ }^{\mathrm{b}}$} \\
\hline & Module completion & Course completion & Module completion & Course completion \\
\hline \multirow[t]{2}{*}{ Female } & $0.016^{*}$ & 0.017 & $0.024 * * *$ & $0.056^{* * *}$ \\
\hline & $(0.008)$ & $(0.016)$ & $(0.005)$ & $(0.013)$ \\
\hline \multirow[t]{2}{*}{ Disability } & 0.002 & 0.008 & $0.028 * *$ & 0.014 \\
\hline & $(0.010)$ & $(0.007)$ & $(0.009)$ & $(0.011)$ \\
\hline \multirow[t]{2}{*}{ Speaks a language other than English at home } & $0.028 * *$ & -0.011 & $0.042 * * *$ & $0.063 * * *$ \\
\hline & $(0.011)$ & $(0.012)$ & $(0.007)$ & $(0.010)$ \\
\hline \multirow[t]{2}{*}{ From lowest quintile of national SES measure (SEIFA) } & $0.030 * * *$ & $0.033^{*}$ & $0.049 * * *$ & $0.065 * *$ \\
\hline & $(0.008)$ & $(0.016)$ & $(0.006)$ & $(0.022)$ \\
\hline \multirow[t]{2}{*}{ Lives outside a capital city } & $0.033 * * *$ & -0.002 & $0.022 * *$ & 0.003 \\
\hline & $(0.005)$ & $(0.009)$ & $(0.009)$ & $(0.007)$ \\
\hline \multirow[t]{2}{*}{ Less than secondary school qualification } & $0.027 * *$ & 0.008 & $0.026 * *$ & $0.031^{*}$ \\
\hline & $(0.010)$ & $(0.012)$ & (0.009) & $(0.015)$ \\
\hline \multirow[t]{2}{*}{ Unemployed } & 0.009 & -0.016 & $0.034 * *$ & 0.016 \\
\hline & $(0.011)$ & $(0.012)$ & $(0.012)$ & $(0.011)$ \\
\hline \multirow[t]{2}{*}{ Public college } & $0.024 * *$ & -0.011 & 0.015 & $0.034 * * *$ \\
\hline & $(0.009)$ & $(0.014)$ & $(0.010)$ & $(0.007)$ \\
\hline \multirow[t]{2}{*}{ Private for profit business } & $0.035^{* * *}$ & $0.046^{* *}$ & $0.075^{* * *}$ & -0.013 \\
\hline & $(0.007)$ & $(0.018)$ & $(0.017)$ & $(0.051)$ \\
\hline \multirow[t]{2}{*}{ Overall } & $0.031 * * *$ & 0.011 & $0.026 * * *$ & $0.041 * * *$ \\
\hline & $(0.008)$ & $(0.011)$ & $(0.007)$ & $(0.010)$ \\
\hline
\end{tabular}


Table 7: Results for the sensitivity analysis, 2010-2012, under standard counterfactual trend assumptions ${ }^{a}$ and constant treatment effects with full set of controls

\begin{tabular}{|c|c|c|c|c|}
\hline & \multicolumn{2}{|c|}{ Course choice } & \multicolumn{2}{|c|}{ Course completion } \\
\hline & $\begin{array}{l}\text { National } \\
\text { skill } \\
\text { shortage }\end{array}$ & $\begin{array}{l}\text { Expected } \\
\text { graduate } \\
\text { earnings }\end{array}$ & $\begin{array}{l}\text { Module } \\
\text { completion }\end{array}$ & $\begin{array}{l}\text { Course } \\
\text { completion }\end{array}$ \\
\hline Standard estimates (Tables 3 and 5) & $0.021 * *$ & 0.004 & $0.031 * * *$ & 0.011 \\
\hline s.e. & $(0.007)$ & $(0.006)$ & $(0.008)$ & $(0.011)$ \\
\hline CI lower $90 \%$ & 0.009 & -0.007 & 0.015 & -0.010 \\
\hline CI upper $90 \%$ & 0.034 & 0.016 & 0.046 & 0.033 \\
\hline Parallel quadratic growth assumptions & $0.043 * *$ & $0.042 * * *$ & $0.017 * *$ & $0.025^{*}$ \\
\hline s.e. & $(0.014)$ & $(0.008)$ & $(0.005)$ & $(0.011)$ \\
\hline CI lower $90 \%$ & 0.017 & 0.026 & 0.007 & 0.003 \\
\hline CI upper $90 \%$ & 0.068 & 0.057 & 0.027 & 0.047 \\
\hline 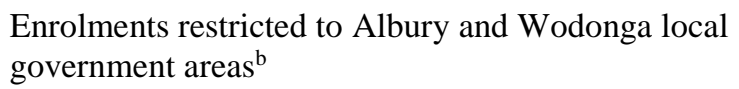 & $0.145^{* * *}$ & $0.046^{* * *}$ & $0.060 * * *$ & $0.107 * * *$ \\
\hline s.e. & $(0.003)$ & $(0.002)$ & $(0.003)$ & $(0.004)$ \\
\hline CI lower $90 \%$ & 0.138 & 0.042 & 0.053 & 0.100 \\
\hline CI upper $90 \%$ & 0.152 & 0.050 & 0.067 & 0.115 \\
\hline Restrict to $18-19$ year-olds & $0.034 * *$ & $0.010^{*}$ & $0.036 * * *$ & $0.024 *$ \\
\hline s.e. & $(0.011)$ & $(0.005)$ & $(0.007)$ & $(0.012)$ \\
\hline CI lower $90 \%$ & 0.014 & 0.000 & 0.022 & 0.001 \\
\hline CI upper $90 \%$ & 0.054 & 0.020 & 0.049 & 0.047 \\
\hline $\begin{array}{l}\text { Omit enrolments from August } 2008 \text { to December } \\
2009\end{array}$ & $0.018 * *$ & 0.005 & $0.025 * *$ & 0.005 \\
\hline s.e. & $(0.007)$ & $(0.006)$ & $(0.010)$ & $(0.013)$ \\
\hline CI lower $90 \%$ & 0.004 & -0.006 & 0.006 & -0.020 \\
\hline CI upper $90 \%$ & 0.032 & 0.016 & 0.045 & 0.029 \\
\hline Omit enrolments from July 2012 & $0.019 * *$ & 0.008 & $0.029 * *$ & 0.012 \\
\hline s.e. & $(0.006)$ & $(0.005)$ & $(0.009)$ & $(0.013)$ \\
\hline CI lower $90 \%$ & 0.007 & -0.002 & 0.013 & -0.013 \\
\hline CI upper $90 \%$ & 0.031 & 0.018 & 0.046 & 0.037 \\
\hline Include college fixed effects & $0.036^{* * *}$ & 0.012 & - & - \\
\hline s.e. & $(0.003)$ & $(0.007)$ & - & - \\
\hline CI lower $90 \%$ & 0.030 & -0.001 & - & - \\
\hline CI upper $90 \%$ & 0.042 & 0.025 & - & - \\
\hline Include college and provider fixed effects & - & - & $0.020 * *$ & 0.021 \\
\hline s.e. & - & - & $(0.006)$ & $(0.012)$ \\
\hline CI lower $90 \%$ & - & - & 0.009 & -0.001 \\
\hline CI upper $90 \%$ & - & - & 0.032 & 0.043 \\
\hline Excluding fee-for-service courses & $0.017 * *$ & 0.003 & $0.037 * * *$ & 0.016 \\
\hline s.e. & $(0.007)$ & $(0.007)$ & $(0.009)$ & $(0.011)$ \\
\hline CI lower $90 \%$ & 0.004 & -0.01 & 0.021 & -0.005 \\
\hline CI upper $90 \%$ & 0.029 & 0.015 & 0.053 & 0.037 \\
\hline Excluding courses not linked to an occupation & - & -0.003 & - & - \\
\hline s.e. & - & -0.005 & - & - \\
\hline CI lower $90 \%$ & - & -0.011 & - & - \\
\hline
\end{tabular}




\section{CI upper $90 \%$}

Excluding expected wages with missing 4-digit cells

s.e.

CI lower $90 \%$

CI upper $90 \%$

Wild bootstrapped standard errors

s.e.

CI lower $90 \%$

CI upper $90 \%$
$-$

0.006

0.001

$(0.007)$

$-0.011$

0.014
$0.031 *$

0.012

$\begin{array}{llll}0.21 * * * & 0.004 & 0.031 * & 0.012\end{array}$

$(0.000)$

(0.007)

(0.017)

$(0.013)$

0.021

$-0.008$

0.003

$-0.01$

0.016

0.059

0.033

***Significant at $1 \%$, **significant at $5 \%$ and $*$ significant at $10 \%$. Unless otherwise stated, results are generated with a full set of student and college controls with state cluster-robust standard errors and critical values from $\mathrm{T}(8-1)$ distribution.

${ }^{a}$ Counterfactual outcomes in Victoria are assumed to follow a parallel path to those of the Rest of Australia. ${ }^{b}$ Local government areas (LGAs) is an Australian standard geographical classification that covers the administrative boundaries of local governments, similar to counties in the United States. The LGAs of Albury (in Victoria) and Wodonga (in NSW) are divided by the Murray River, which is the Victoria and NSW state border. This model is estimated on a sample size of 1962 and 3073 observations for national skill shortage and course graduate wage respectively. Standard errors are robust-clustered at the state level with $\mathrm{T}(2-1)$ critical values. ${ }^{\mathrm{c}} \mathrm{We}$ use the cgmwildboot program (provided by Judson Caskey, https://sites.google.com/site/judsoncaskey/data) to estimate p-values based on wild bootsrapped standard errors clustered at the state and territory level with 1000 draws. The program produces p-values (reported in square brackets) that are based on empirical $\mathrm{T}(8-1)$ distribution. 


\section{Endnotes}

${ }^{1}$ Two recent examples of reforms are The Skills for Sustainable Growth reforms introduced in England in 2012/13 and the Educating Tomorrow's Workforce Act 2015 in the US. The former aimed to provide greater contestability between VET colleges for public funding by granting 19-24 year-olds an entitlement to a government-funded place in training for basic level courses, which they could use to enrol in any course of their choosing. The latter attempted to make community college enrolments more responsive to local skill needs by linking annual federal funding allocations to measures of how closely course offerings are aligned to locallyidentified skill needs.

${ }^{2}$ See OECD (2010) and OECD (2014) for ambitious attempts at such comparisons.

${ }^{3}$ Most media reports pointed to large increases in enrolment in specific courses in areas outside of skill shortage areas, such as health and fitness training, as evidence that the reforms were not working, but ignored growth in enrolments in areas that were in skill need, such as aged care and child care. Examples of these negative reports are: 'Market design fails to supply the skills', Australian Financial Review, 3 July 2012; 'Match training to needs: business', Australian Financial Review, 3 July 2012; 'Free market could limit skills: TAFE', The Australian, 12 January 2012.

${ }^{4}$ In 2008, Victoria was close to an election year (2010). Its centre-left government had been in office for almost ten years and its long-serving Premier resigned for personal reasons in July 2007. Faced with flagging political fortunes after a long term in office and slowing economic growth, the new Premier John Bracks took over with the intention of re-invigorating the party in the run-up to the 2010 election. Renewed commitment to education was a central focus and it was these political interests that were the key driver of Victoria's early adoption of the national reforms.

5 The voucher schemes introduced in other states were much more limited than the VTG. Essentially, enrolments under the other state voucher schemes were limited to courses on government priority lists.

${ }^{6}$ In 2008, 27\% of Victorians aged 15-19 in publicly-funded courses were undertaking apprenticeships or traineeships (National VET Provider Collection).

${ }^{7}$ In July 2012, the Victorian government partially unwound the 2009 reforms by making course subsidies more targeted towards perceived employer demand for graduates.

${ }^{8}$ In practice, direct tuition fees were regulated according to course level in each state, with a prescribed hourly rate and a minimum and maximum total annual fee. In Victoria, hourly fees for lower-level courses (certificates I and II, equivalent to ISCED2) were up to $\$ 1.51$ per hour in 2011 , with a minimum total fee of $\$ 187.50$ and a 
maximum total fee of $\$ 875$. The highest fees were for Diploma level courses - up to $\$ 3.79$ per hour, minimum total fee of $\$ 375$ and a maximum total fee of $\$ 2000$. Many students were also eligible for reduced fees, e.g. on the grounds of receiving Income Support (welfare).

${ }^{9}$ Relevant requirements for registration include to make reasonable adjustments to accommodate people with disability (under the Disability Discrimination Act 1992), and to adopt policies and approaches aimed at ensuring VET colleges respond to the individual needs of clients whose age, gender, cultural or ethnic background, disability, sexuality, language skills, literacy or numeracy level, unemployment, imprisonment or remote location may present a barrier to access, participation and the achievement of suitable outcomes.

${ }^{10}$ LSAY 2003 tracks the cohort of 15 year-old students who participated in the OECD Program for International Student Assessment (PISA) in 2003 (around 10,000 students) annually until age 25. Fee-for-service estimates in private colleges are estimated as the share of 17-19 year-old school leavers/graduates in 2005-07 who enrol in non-government colleges, excluding apprentices and trainees because they are all entitled to a publicly-funded place in training. This is likely to be an over-estimate because prior to reform private colleges were also able to tender for small-scale public training contracts, such as training programs for public sector employees.

${ }^{11}$ These occupations are at the Australian and New Zealand Standard Classification of Occupation (ANZSCO) 6-digit level. There are 998 ANZSCO 6-digit occupations in all. Skill shortage lists are compiled by the Department of Employment: https://www.employment.gov.au/skill-shortages.

${ }^{12}$ Grogger and Eide (1995) and Avery and Turner (2012), for example, do something similar to estimate returns to different college majors in the US. Where there are sparse cells, results estimated with course level and 2digit field of study combinations are used. Field of study is 4-digit Australian Standard Classification of Education (ASCED).

${ }^{13}$ See http://www.ncver.edu.au/sos for further details on the SOS.

${ }^{14}$ Earnings data are reported in bands from which this analysis uses the midpoint.

${ }^{15}$ See supplementary material for tests of diverging pre-reform trends.

${ }^{16}$ Implemented by introducing state-specific trend terms coded $-3,-2, \ldots, 2,3$ corresponding to the years 2006 to 2012 respectively.

${ }^{17}$ Match Training to Needs: Business. The Australian Financial Review (3/7/2012).

${ }^{18}$ The reduction in graduate earnings in 2011 is estimated using conditional difference-in-difference analysis using SOS graduate earnings data. The lack of response to the fall in 2011 earnings in skills shortage areas in 2012 is demonstrated by re-estimating unconditional difference-in-difference models under standard 
counterfactual assumptions (equation 1) with expected graduate earnings fixed at 2010 levels for students enrolling in 2012. Under this scenario, the result in 2012 is much more positive and statistically significant (Table A7).

${ }^{19} \mathrm{We}$ have also estimated the same sensitivity tests under alternative trend assumptions (diverging linear trends). Results from these tests produce the same conclusions, that is, results are not sensitive to alternative model specifications - treatment effects have the same sign and statistical significance as under the standard model specification (see Table A8 from the supplementary material).

${ }^{20}$ The Albury-Wodonga economy is not typical of Australian inland towns that usually rely heavily on agriculture. A legacy of decentralisation policies in the 1970s and its history as a transport hub, the AlburyWodonga economy depends heavily on manufacturing and business services that require workers with trade, engineering and other technical training. However, twenty-five consecutive years of economic growth in Australia has led to skill shortages in many of skill areas and inland towns far from capital cities, such as Albury-Wodonga, have struggled to attract the required skilled workers (see Cameron 2011 for an overview of prevailing skill shortage problems in inland Australian towns). Albury-Wodonga is situated on the main highway joining the two largest capital cities in Australia, Sydney and Melbourne. It is 553km south of Sydney and $325 \mathrm{~km}$ north of Melbourne. The towns were formed in the $1830 \mathrm{~s}$ on opposite banks of the river to accommodate the transportation of goods between the two main Australian colonies and as customs houses to collect duties on goods travelling between the two colonies. 


\section{Course Choice and Achievement Effects of a System-wide Vocational Education and Training Voucher Scheme for Young People: Supplementary Material}

Table A1 defines the control variables included in (1) in the main paper. Table A2 provides further descriptive information on the national skills shortage lists behind one of the course choice measures. Table A3 gives the estimated wage premia associated with different qualifications that lie behind the second course choice measure in the main paper. Table A4 provides estimates from tests for pre-reform diverging trends for all outcomes on the prereform sample. Table A5 shows courses that experience the largest average post-reform enrolment growth — those with more than 500 extra enrolments per annum. Table A6 presents the key results from analysis using the Student Outcome Survey that show the impact of the VTG on graduate wages in skill shortage areas. The results presented in Table A7 are from equation (2) in the main paper with course demand information associated with 2012 enrolments restricted to that faced by students enrolled in 2011. Tables A8 are results for the sensitivity tests presented in Table 7, except with linear time trends. 
Table A1: Description of control variables

Variable Description

Student characteristics

Female

Age in years on January 1 in the year of enrolment

Aboriginal or Torres Strait Islander

Migrant status and language spoken at home

Regional classification of residence

Employed at time of enrolment

Has a disability

Socio-economic status of residential area

Highest prior level of education completed

\section{Dummy variable of gender}

Dummy variable derived from the date of birth. To be eligible for the VTG, course applicants must provide evidence to verify their date of birth

Self-identified as being from Aboriginal or Torres Strait Island decent

Migrant status is self-reported country of birth, which is collapsed into whether or not the student is born overseas. Language other than English spoken at home is the reported main language spoken at home other than English (if any). All languages other than English are bundled together as nonEnglish speaking.

These are categories of remoteness, measured by distance to major services, produced by the Australian Bureau of Statistics (ABS) (2011a). These categories were assigned to the residential postcodes in the VETPC using correspondence between residential postcode and remoteness areas obtained from the ABS.

Students are asked which of a number of employment states best describes their current situation. Our binary measure of employed includes people who report being part-time employed, full-time employed and self-employed. All other states (unpaid worker, unemployed and looking for work and unemployed and not seeking work) are grouped together.

Student self-reported belief about whether they have a disability, impairment or long-term health condition. This information is used by colleges to identify students who may need extra support to cater for any special learning needs.

This is the relative disadvantage of the local government area (LGA) in which the student resides, measured using the Social Economic Index of Areas (SEIFA) produced by the Australian Bureau of Statistics (2011b). SEIFA is an ordinal index of regional disadvantage, combining measures such as percentage of people who are low income and percentage of people who have less than secondary school education from the Australian census. We break the national index into quintiles, where the lowest quintile contains the most disadvantaged postcodes in Australia. The SEIFA quintiles were assigned to students in the VETPC using concordance between postcode and LGA obtained from the Australian Bureau of Statistics.

Highest prior education is a combination of information on the student reported highest year of school successfully completed and the reported Australian Standard Classification of Education 
(ASCED) post-school qualifications completed. The highest post-school qualification is determined according to the International Standard Classification of Education (ISCED) 1997 (United National Educational, Scientific and Cultural Organisation (UNESCO) 2006) qualification rankings and concordance between ASCED and ISCED (Australian Bureau of Statistics 2001).

\section{College characteristics}

Number of enrolments in 2008

Type of college

Course characteristics

Course qualification level

Field of study (4-digit ASCED)

National skill shortage indicator
Number of 15-19 year-old new enrolments in 2008 for each college identified in VETPC between 2008 and 2011. New colleges that entered the market after 2008 are treated as a separate category.

College type in the VETPC is classified according to the governance characteristics of the organisation providing the training. Technical and Further Education (TAFE) colleges are the main public colleges, which were created by Act of Parliament and have responsibilities specified in their establishing Acts, other legislation and Ministerial Directions. Adult and Community Education (ACE) colleges are also public colleges. They differ from TAFEs in that their primary focus is adult education and as well as providing nationally accredited courses for preparation for work, they also provide personal and recreational courses (that are not included in this study). The third type of public college is dual sector universities that offer both VET qualifications and bachelor degrees. In contrast to public colleges, private businesses (commercial colleges) are registered colleges that provide nationally recognised training on a for-profit basis. In between public and private businesses are enterprises, industry associations and other non-government organisations that are registered training organisations that provide nationally accredited training to meet the needs of their members or employees.

Under the Australian Qualification Framework (AQF) (Australian Quality Framework Council 2013), nationally accredited VET courses are one of six ASCED levels from Certificate I through to Advanced Diploma. For the analysis, we combine Diploma level courses and Advanced Diploma level courses to produce five qualification categories. These are equivalent to ISCED (1997) 2C through to ISCED 5B (ABS 2001). There are also a small number of low level VET courses outside the AQF system that are termed certificates of attainment.

The field of course study is at the 4-digit Australian Standard Classification of Education level (Australian Bureau of Statistics 2001). There are 71 categories in total.

Binary measure of whether the course is associated with preparation for work in a skill shortage occupation. Skill shortage occupations are those that at the start of the year of enrolment are listed by the Department of Education to be of national shortage. General courses of mixed field courses that are not associated with preparation for a particular occupation are coded zero. We also include a binary indicator for these courses. 
This is identical to the dependent variable for course choice and represents the estimated log earnings premium ( $\mathrm{A}$ \$2013) for graduates for different field of study and course level

combinations, relative to Building certificate level III. See the data description in section 3 for more information and Table A3 for the estimated earnings premia. 
Table A2: Occupations on the National Skill Shortage List, 2006-2012 ${ }^{\text {a }}$

\begin{tabular}{|c|c|c|c|c|c|c|c|c|}
\hline & 2006 & 2007 & 2008 & 2009 & 2010 & 2011 & 2012 & Total \\
\hline Construction Project Manager & 0 & 0 & 0 & 0 & 0 & 1 & 1 & 2 \\
\hline Engineering Manager & 0 & 0 & 1 & 1 & 0 & 1 & 1 & 4 \\
\hline Production Manager (Mining) & 0 & 0 & 1 & 1 & 0 & 1 & 1 & 4 \\
\hline Child Care Centre Manager & 1 & 1 & 1 & 1 & 1 & 1 & 1 & 7 \\
\hline Accountant (General) & 1 & 1 & 1 & 1 & 0 & 0 & 0 & 4 \\
\hline Management Accountant & 1 & 1 & 1 & 1 & 0 & 0 & 0 & 4 \\
\hline Taxation Accountant & 1 & 1 & 1 & 1 & 0 & 0 & 0 & 4 \\
\hline External Auditor & 0 & 1 & 1 & 1 & 0 & 0 & 0 & 3 \\
\hline Architect & 0 & 1 & 1 & 1 & 0 & 0 & 0 & 3 \\
\hline Surveyor & 0 & 1 & 1 & 1 & 1 & 1 & 1 & 6 \\
\hline Urban and Regional Planner & 1 & 0 & 1 & 1 & 0 & 0 & 0 & 3 \\
\hline Chemical Engineer & 1 & 1 & 1 & 1 & 1 & 0 & 0 & 5 \\
\hline Civil Engineer & 1 & 1 & 1 & 1 & 1 & 1 & 1 & 7 \\
\hline Quantity Surveyor & 0 & 1 & 1 & 1 & 1 & 1 & 1 & 6 \\
\hline Structural Engineer & 1 & 1 & 1 & 1 & 1 & 1 & 1 & 7 \\
\hline Transport Engineer & 1 & 1 & 1 & 1 & 1 & 1 & 1 & 7 \\
\hline Electrical Engineer & 1 & 1 & 1 & 1 & 1 & 1 & 1 & 7 \\
\hline Electronics Engineer & 0 & 0 & 1 & 1 & 0 & 0 & 0 & 2 \\
\hline Mechanical Engineer & 0 & 1 & 1 & 1 & 0 & 1 & 1 & 5 \\
\hline Production or Plant Engineer & 0 & 0 & 0 & 1 & 0 & 0 & 0 & 1 \\
\hline Mining Engineer (excluding Petroleum) & 1 & 1 & 1 & 1 & 1 & 1 & 1 & 7 \\
\hline Petroleum Engineer & 1 & 0 & 1 & 0 & 1 & 1 & 1 & 5 \\
\hline Agricultural Consultant & 0 & 0 & 1 & 1 & 1 & 1 & 1 & 5 \\
\hline Agricultural Scientist & 0 & 0 & 1 & 1 & 1 & 1 & 1 & 5 \\
\hline Forester (Aus) / Forest Scientist (NZ) & 0 & 0 & 1 & 1 & 0 & 0 & 0 & 2 \\
\hline Geologist & 1 & 1 & 1 & 1 & 0 & 1 & 1 & 6 \\
\hline Veterinarian & 0 & 0 & 0 & 0 & 1 & 1 & 0 & 2 \\
\hline Metallurgist & 1 & 0 & 0 & 0 & 0 & 0 & 0 & 1 \\
\hline \multicolumn{9}{|c|}{ Early Childhood (Pre-primary School) Teacher } \\
\hline & 0 & 0 & 0 & 0 & 1 & 1 & 1 & 3 \\
\hline Special Needs Teacher & 0 & 0 & 0 & 0 & 1 & 0 & 0 & 1 \\
\hline Medical Diagnostic Radiographer & 1 & 1 & 1 & 1 & 1 & 1 & 0 & 6 \\
\hline Medical Radiation Therapist & 1 & 0 & 1 & 0 & 0 & 1 & 0 & 3 \\
\hline Nuclear Medicine Technologist & 1 & 0 & 0 & 0 & 0 & 0 & 0 & 1 \\
\hline Sonographer & 1 & 1 & 1 & 1 & 1 & 1 & 1 & 7 \\
\hline Optometrist & 0 & 0 & 1 & 1 & 1 & 0 & 1 & 4 \\
\hline Hospital Pharmacist & 1 & 1 & 1 & 1 & 0 & 0 & 0 & 4 \\
\hline Retail Pharmacist & 1 & 1 & 1 & 1 & 0 & 0 & 0 & 4 \\
\hline Dental Specialist & 1 & 1 & 1 & 1 & 1 & 0 & 0 & 5 \\
\hline Dentist & 1 & 1 & 1 & 1 & 1 & 0 & 0 & 5 \\
\hline Occupational Therapist & 1 & 1 & 1 & 1 & 1 & 0 & 0 & 5 \\
\hline Physiotherapist & 1 & 1 & 1 & 1 & 1 & 1 & 1 & 7 \\
\hline Podiatrist & 1 & 1 & 1 & 1 & 1 & 1 & 1 & 7 \\
\hline
\end{tabular}


Audiologist

Speech Pathologist (Aus) / Speech Language

Therapist (NZ)

Midwife

Nurse Educator

Nurse Researcher

Nurse Manager

Nurse Practitioner

Registered Nurse (Aged Care)

Registered Nurse (Child and Family Health)

Registered Nurse (Community Health)

Registered Nurse (Critical Care and Emergency)

Registered Nurse (Developmental Disability)

Registered Nurse (Disability and Rehabilitation)

Registered Nurse (Medical)

Registered Nurse (Medical Practice)

Registered Nurse (Mental Health)

Registered Nurse (Perioperative)

Registered Nurse (Surgical)

Registered Nurses nec

Clinical Psychologist

Social Worker

Welfare Worker

Agricultural Technician

Architectural Draftsperson

Building Associate

Construction Estimator

Surveying or Cartographic Technician

Civil Engineering Draftsperson

Civil Engineering Technician

Electrical Engineering Draftsperson

Electrical Engineering Technician

Electronic Engineering Draftsperson

Electronic Engineering Technician

Mechanical Engineering Draftsperson

Metallurgical or Materials Technician

Mine Deputy

Radiocommunications Technician

Automotive Electrician

Diesel Motor Mechanic

Motorcycle Mechanic

Small Engine Mechanic

Sheetmetal Trades Worker

Metal Fabricator

Welder (First Class) (Aus) / Welder (NZ) 
Aircraft Maintenance Engineer (Avionics)

Aircraft Maintenance Engineer (Mechanical)

Fitter (General)

Fitter and Turner

Fitter-Welder

Metal Machinist (First Class)

Textile, Clothing and Footwear Mechanic

Metal Fitters and Machinists nec

Locksmith

Toolmaker

Panelbeater

Vehicle Body Builder

Vehicle Trimmer

Vehicle Painter

Bricklayer

Stonemason

Carpenter and Joiner

Carpenter

Joiner

Floor Finisher

Painting Trades Worker

Glazier

Fibrous Plasterer

Solid Plasterer

Roof Tiler

Wall and Floor Tiler

Plumber (General)

Airconditioning and Mechanical Services

Plumber

Drainer (Aus) / Drainlayer (NZ)

Gasfitter

Roof Plumber

Electrician (General)

Electrician (Special Class)

Lift Mechanic

Airconditioning and Refrigeration Mechanic

Electrical Linesworker (Aus) / Electrical Line Mechanic (NZ)

Electronic Equipment Trades Worker

Electronic Instrument Trades Worker (General)

Cabler (Data and Telecommunications)

Telecommunications Cable Jointer

Telecommunications Linesworker (Aus) /

Telecommunications Line Mechanic (NZ)

Telecommunications Technician

Baker

\begin{tabular}{|c|c|c|c|c|c|c|}
\hline 0 & 1 & 1 & 1 & 1 & 1 & 0 \\
\hline 0 & 1 & 1 & 1 & 1 & 1 & 0 \\
\hline 0 & 1 & 1 & 1 & 1 & 1 & 0 \\
\hline 0 & 1 & 1 & 1 & 1 & 1 & 0 \\
\hline 0 & 1 & 1 & 1 & 1 & 1 & 0 \\
\hline 1 & 1 & 1 & 1 & 0 & 1 & 1 \\
\hline 1 & 1 & 1 & 1 & 0 & 1 & 1 \\
\hline 1 & 1 & 1 & 1 & 0 & 1 & 1 \\
\hline 1 & 1 & 1 & 1 & 1 & 1 & 1 \\
\hline 1 & 1 & 1 & 0 & 0 & 1 & 0 \\
\hline 1 & 1 & 1 & 1 & 1 & 1 & 1 \\
\hline 1 & 1 & 1 & 1 & 0 & 0 & 1 \\
\hline 0 & 1 & 1 & 1 & 1 & 1 & 1 \\
\hline 1 & 1 & 1 & 1 & 0 & 1 & 1 \\
\hline 1 & 1 & 1 & 1 & 0 & 1 & 0 \\
\hline 1 & 1 & 1 & 1 & 0 & 0 & 0 \\
\hline 1 & 1 & 1 & 1 & 0 & 0 & 0 \\
\hline 1 & 1 & 1 & 1 & 0 & 0 & 0 \\
\hline 1 & 1 & 1 & 1 & 0 & 0 & 0 \\
\hline 1 & 1 & 1 & 1 & 1 & 0 & 0 \\
\hline 0 & 1 & 1 & 1 & 0 & 0 & 0 \\
\hline 1 & 1 & 1 & 1 & 1 & 1 & 0 \\
\hline 1 & 1 & 1 & 1 & 0 & 1 & 1 \\
\hline 1 & 1 & 1 & 1 & 0 & 1 & 1 \\
\hline 1 & 1 & 1 & 1 & 0 & 1 & 1 \\
\hline 1 & 1 & 1 & 1 & 0 & 1 & 1 \\
\hline 1 & 1 & 1 & 1 & 0 & 1 & 1 \\
\hline 1 & 1 & 1 & 1 & 0 & 1 & 1 \\
\hline 1 & 1 & 1 & 1 & 0 & 1 & 1 \\
\hline 1 & 1 & 1 & 1 & 0 & 1 & 1 \\
\hline 1 & 1 & 1 & 1 & 0 & 1 & 1 \\
\hline 1 & 1 & 1 & 1 & 0 & 0 & 1 \\
\hline 1 & 0 & 0 & 0 & 0 & 0 & 0 \\
\hline 1 & 1 & 1 & 1 & 1 & 0 & 0 \\
\hline 1 & 1 & 1 & 1 & 1 & 1 & 1 \\
\hline 1 & 1 & 1 & 1 & 1 & 1 & 1 \\
\hline 1 & 1 & 1 & 1 & 1 & 0 & 1 \\
\hline 1 & 0 & 0 & 0 & 0 & 1 & 1 \\
\hline 0 & 0 & 1 & 1 & 0 & 0 & 0 \\
\hline 0 & 0 & 0 & 0 & 0 & 0 & 1 \\
\hline 0 & 0 & 1 & 1 & 0 & 0 & 0 \\
\hline 0 & 0 & 1 & 1 & 0 & 0 & 1 \\
\hline 1 & 1 & 1 & 1 & 1 & 1 & 1 \\
\hline
\end{tabular}


Pastrycook

Butcher or Smallgoods Maker

Chef

Cook

Shearer

Arborist

Landscape Gardener

Hairdresser

Binder and Finisher

Screen Printer

Graphic Pre-press Trades Worker

Printing Machinist

Small Offset Printer

Upholsterer

Cabinetmaker

Furniture Finisher

Picture Framer

Wood Machinist

Boat Builder and Repairer

Jeweller

Signwriter

Optical Dispenser (Aus) / Dispensing Optician

(NZ)

Dental Technician

Enrolled Nurse

Child Care Worker

Miner

Total

\begin{tabular}{|c|c|c|c|c|c|c|c|}
\hline 1 & 1 & 1 & 1 & 1 & 1 & 0 & 6 \\
\hline 1 & 1 & 1 & 1 & 1 & 1 & 1 & 7 \\
\hline 1 & 1 & 1 & 1 & 1 & 1 & 1 & 7 \\
\hline 1 & 1 & 1 & 1 & 1 & 1 & 1 & 7 \\
\hline 0 & 0 & 1 & 1 & 0 & 0 & 1 & 3 \\
\hline 1 & 1 & 1 & 1 & 1 & 1 & 1 & 7 \\
\hline 0 & 0 & 1 & 1 & 1 & 0 & 1 & 4 \\
\hline 1 & 1 & 1 & 1 & 1 & 1 & 1 & 7 \\
\hline 1 & 1 & 1 & 1 & 1 & 1 & 0 & 6 \\
\hline 1 & 1 & 1 & 1 & 1 & 0 & 0 & 5 \\
\hline 0 & 0 & 0 & 0 & 1 & 0 & 0 & 1 \\
\hline 1 & 1 & 1 & 0 & 0 & 0 & 0 & 3 \\
\hline 1 & 0 & 0 & 0 & 0 & 0 & 0 & 1 \\
\hline 1 & 1 & 1 & 1 & 1 & 0 & 0 & 5 \\
\hline 1 & 1 & 1 & 1 & 1 & 1 & 0 & 6 \\
\hline 1 & 1 & 1 & 1 & 1 & 0 & 0 & 5 \\
\hline 0 & 1 & 1 & 1 & 1 & 0 & 0 & 4 \\
\hline 0 & 1 & 1 & 1 & 0 & 0 & 0 & 3 \\
\hline 1 & 1 & 1 & 1 & 0 & 0 & 1 & 5 \\
\hline 0 & 0 & 0 & 0 & 1 & 0 & 1 & 2 \\
\hline 0 & 1 & 1 & 1 & 1 & 0 & 0 & 4 \\
\hline 0 & 1 & 1 & 1 & 1 & 0 & 0 & 4 \\
\hline 0 & 1 & 1 & 1 & 1 & 0 & 1 & 5 \\
\hline 1 & 0 & 0 & 1 & 1 & 1 & 1 & 5 \\
\hline 1 & 0 & 1 & 1 & 1 & 1 & 1 & 6 \\
\hline 1 & 0 & 1 & 1 & 1 & 1 & 1 & 6 \\
\hline 107 & 114 & 135 & 135 & 77 & 94 & 94 & 756 \\
\hline
\end{tabular}

Information on skill demand, including national shortage information used in the analysis is annual information from the year prior to enrolment (2005-2011). This is the best estimate of information available at the time course choice. Not on list does not necessarily mean that there is weak demand for course graduates trained for work in a given occupation. Occupations in the table (out of a total 998 occupations) are those that appear on the national skill shortage list at least once over the period of analysis. Occupations not on the national shortage list may be regionally, but not nationally, in shortage. In some cases, occupations may not be in the list because there is no evidence available on the extent of the skill shortage. 
Table A3: Estimated log weekly wage coefficients (\$A2013) by ISCED 4-digit field of study and qualification level

\begin{tabular}{|c|c|c|c|c|c|c|c|c|}
\hline ISCED 4-digit field of study & Level & 2006 & 2007 & 2008 & 2009 & 2010 & 2011 & 2012 \\
\hline & & - & & & & . & & - \\
\hline \multirow[t]{2}{*}{ Accounting } & Cert. I & 0.09 & 0.04 & 0.05 & 0.46 & 0.01 & 0.01 & 0.03 \\
\hline & & & - & - & - & & & - \\
\hline \multirow[t]{2}{*}{ Accounting } & Cert. II & 0.02 & 0.02 & 0.04 & 0.07 & 0.04 & 0.11 & 0.06 \\
\hline & & & & - & & & & - \\
\hline \multirow{2}{*}{ Accounting } & Cert. III & 0.13 & 0.51 & 0.46 & 0.52 & 0.10 & 0.11 & 0.15 \\
\hline & & - & - & - & - & - & - & - \\
\hline \multirow[t]{2}{*}{ Accounting } & Cert. IV & 0.24 & 0.13 & 0.24 & 0.20 & 0.20 & 0.20 & 0.27 \\
\hline & & - & - & - & - & - & - & - \\
\hline \multirow[t]{2}{*}{ Accounting } & Diploma+ & 0.06 & 0.29 & 0.28 & 0.37 & 0.29 & 0.33 & 0.25 \\
\hline & & - & - & & & - & - & - \\
\hline \multirow[t]{2}{*}{ Aerospace Engineering and Technology } & Cert. I & 0.31 & 0.66 & 0.14 & 0.19 & 0.15 & 0.28 & 0.09 \\
\hline & & & - & & - & & - & - \\
\hline \multirow[t]{2}{*}{ Aerospace Engineering and Technology } & Cert. II & 0.22 & 0.59 & 0.07 & 0.10 & 0.00 & 0.20 & 0.24 \\
\hline & & & - & - & - & - & & \\
\hline \multirow[t]{2}{*}{ Aerospace Engineering and Technology } & Cert. III & 0.04 & 0.04 & 0.01 & 0.05 & 0.03 & 0.00 & 0.01 \\
\hline & & - & - & - & - & - & - & - \\
\hline \multirow[t]{2}{*}{ Aerospace Engineering and Technology } & Cert. IV & 0.04 & 0.67 & 0.36 & 0.56 & 0.50 & 0.32 & 0.19 \\
\hline & & - & - & - & - & - & - & - \\
\hline \multirow[t]{2}{*}{ Aerospace Engineering and Technology } & Diploma+ & 0.08 & 0.18 & 0.54 & 0.35 & 0.21 & 0.14 & 0.14 \\
\hline & & & & - & - & - & - & - \\
\hline \multirow[t]{2}{*}{ Agriculture } & Cert. I & 0.08 & 0.06 & 0.21 & 0.09 & 0.08 & 0.35 & 0.15 \\
\hline & & - & - & - & - & - & - & - \\
\hline \multirow[t]{2}{*}{ Agriculture } & Cert. II & 0.03 & 0.22 & 0.31 & 0.19 & 0.20 & 0.07 & 0.20 \\
\hline & & - & - & - & - & - & - & \\
\hline \multirow[t]{2}{*}{ Agriculture } & Cert. III & 0.08 & 0.20 & 0.20 & 0.19 & 0.20 & 0.35 & 0.00 \\
\hline & & - & - & - & - & - & - & - \\
\hline \multirow[t]{2}{*}{ Agriculture } & Cert. IV & 0.08 & 0.32 & 0.12 & 0.09 & 0.20 & 0.20 & 0.24 \\
\hline & & - & - & - & - & - & - & - \\
\hline \multirow[t]{2}{*}{ Agriculture } & Diploma+ & 0.30 & 0.15 & 0.30 & 0.04 & 0.27 & 0.64 & 0.44 \\
\hline & & & - & - & - & - & - & - \\
\hline \multirow[t]{2}{*}{ Architecture and Urban Environment } & Cert. I & 0.18 & 0.05 & 0.10 & 0.11 & 0.24 & 0.12 & 0.18 \\
\hline & & & - & & - & - & - & - \\
\hline Architecture and Urban Environment & Cert. II & 0.11 & 0.23 & 0.00 & 0.43 & 0.35 & 0.12 & 0.22 \\
\hline \multirow[t]{2}{*}{ Architecture and Urban Environment } & Cert. III & - & - & - & - & - & - & - \\
\hline & & - & - & - & - & - & - & - \\
\hline \multirow[t]{2}{*}{ Architecture and Urban Environment } & Cert. IV & 0.21 & 0.31 & 0.24 & 0.35 & 0.25 & 0.30 & 0.16 \\
\hline & & - & - & - & - & - & - & - \\
\hline Architecture and Urban Environment & Diploma+ & 0.11 & 0.26 & 0.15 & 0.18 & 0.18 & 0.16 & 0.21 \\
\hline & & & - & & - & - & - & \\
\hline Automotive Engineering and Technology & Cert. I & 0.03 & 0.13 & 0.05 & 0.17 & 0.47 & 0.04 & 0.03 \\
\hline & & - & - & - & - & - & & \\
\hline Automotive Engineering and Technology & Cert. II & 0.07 & 0.57 & 0.14 & 0.12 & 0.16 & 0.30 & 0.24 \\
\hline & & - & - & - & - & - & - & - \\
\hline Automotive Engineering and Technology & Cert. III & 0.05 & 0.15 & 0.08 & 0.17 & 0.12 & 0.10 & 0.09 \\
\hline & & - & - & - & - & - & - & - \\
\hline Automotive Engineering and Technology & Cert. IV & 0.13 & 0.16 & 0.14 & 0.22 & 0.22 & 0.21 & 0.16 \\
\hline & & - & - & - & - & - & - & - \\
\hline Automotive Engineering and Technology & Diploma+ & 0.12 & 0.28 & 0.18 & 0.31 & 0.20 & 0.27 & 0.20 \\
\hline & & & - & - & - & - & - & - \\
\hline Banking, Finance and Related Fields & Cert. I & 0.05 & 0.13 & 0.01 & 0.08 & 0.11 & 0.08 & 0.08 \\
\hline & & - & - & & & & - & - \\
\hline Banking, Finance and Related Fields & Cert. II & 0.11 & 0.10 & 0.01 & 0.04 & 0.03 & 0.01 & 0.06 \\
\hline
\end{tabular}




\begin{tabular}{|c|c|c|c|c|c|c|c|c|}
\hline Banking, Finance and Related Fields & Cert. III & $\begin{array}{l}0.06 \\
-\end{array}$ & $\begin{array}{l}0.05 \\
-\end{array}$ & 0.07 & $\begin{array}{l}0.13 \\
-\end{array}$ & $\begin{array}{l}0.12 \\
-\end{array}$ & 0.06 & $\begin{array}{l}0.08 \\
-\end{array}$ \\
\hline Banking, Finance and Related Fields & Cert. IV & 0.04 & 0.15 & 0.00 & 0.28 & 0.67 & 0.11 & 0.54 \\
\hline Banking, Finance and Related Fields & Diploma+ & 0.06 & $\begin{array}{l}- \\
0.29\end{array}$ & $\begin{array}{l}- \\
0.28\end{array}$ & $\begin{array}{l}- \\
0.37\end{array}$ & $\begin{array}{l}- \\
0.29\end{array}$ & $\begin{array}{l}- \\
0.33\end{array}$ & $\begin{array}{l}- \\
0.25\end{array}$ \\
\hline Biological Sciences & Cert. I & 0.40 & $\begin{array}{l}0.14 \\
-\end{array}$ & $\begin{array}{l}0.19 \\
-\end{array}$ & $\begin{array}{l}0.01 \\
-\end{array}$ & 0.14 & 0.20 & 0.02 \\
\hline Biological Sciences & Cert. II & $\begin{array}{l}0.05 \\
-\end{array}$ & $\begin{array}{l}0.32 \\
-\end{array}$ & $\begin{array}{l}0.14 \\
-\end{array}$ & $\begin{array}{l}0.29 \\
-\end{array}$ & $\begin{array}{l}0.47 \\
-\end{array}$ & 0.07 & 0.23 \\
\hline Biological Sciences & Cert. III & 0.18 & 0.46 & $\begin{array}{l}0.09 \\
-\end{array}$ & 0.06 & $\begin{array}{l}0.04 \\
-\end{array}$ & $\begin{array}{l}0.01 \\
-\end{array}$ & 0.02 \\
\hline Biological Sciences & Cert. IV & - & - & 0.92 & - & 0.62 & 0.27 & - \\
\hline Biological Sciences & Diploma+ & - & - & - & - & - & - & - \\
\hline Building & Cert. I & 0.02 & 0.03 & 0.03 & 0.02 & 0.08 & 0.05 & 0.00 \\
\hline Building & Cert. II & 0.27 & 0.10 & 0.12 & 0.13 & 0.07 & 0.14 & 0.15 \\
\hline Building (reference case) & Cert. III & $\begin{array}{l}\mathbf{0 . 0 0} \\
-\end{array}$ & $\begin{array}{l}\mathbf{0 . 0 0} \\
-\end{array}$ & $\begin{array}{l}\mathbf{0 . 0 0} \\
-\end{array}$ & $\begin{array}{l}\mathbf{0 . 0 0} \\
-\end{array}$ & $\begin{array}{l}\mathbf{0 . 0 0} \\
-\end{array}$ & $\begin{array}{l}\mathbf{0 . 0 0} \\
-\end{array}$ & $\begin{array}{l}\mathbf{0 . 0 0} \\
-\end{array}$ \\
\hline Building & Cert. IV & $\begin{array}{l}0.22 \\
-\end{array}$ & $\begin{array}{l}0.32 \\
-\end{array}$ & $\begin{array}{l}0.25 \\
-\end{array}$ & $\begin{array}{l}0.36 \\
-\end{array}$ & $\begin{array}{l}0.27 \\
-\end{array}$ & $\begin{array}{l}0.31 \\
-\end{array}$ & $\begin{array}{l}0.17 \\
-\end{array}$ \\
\hline Building & Diploma+ & 0.12 & 0.27 & 0.15 & $\begin{array}{l}0.19 \\
-\end{array}$ & 0.19 & 0.17 & $\begin{array}{l}0.22 \\
-\end{array}$ \\
\hline Business and Management & Cert. I & 0.11 & 0.05 & $\begin{array}{l}0.06 \\
-\end{array}$ & $\begin{array}{l}0.05 \\
-\end{array}$ & $\begin{array}{l}0.00 \\
-\end{array}$ & $\begin{array}{l}0.04 \\
-\end{array}$ & $\begin{array}{l}0.02 \\
-\end{array}$ \\
\hline Business and Management & Cert. II & 0.03 & $\begin{array}{l}0.00 \\
-\end{array}$ & $\begin{array}{l}0.06 \\
-\end{array}$ & $\begin{array}{l}0.11 \\
-\end{array}$ & $\begin{array}{l}0.03 \\
-\end{array}$ & $\begin{array}{l}0.10 \\
-\end{array}$ & $\begin{array}{l}0.08 \\
-\end{array}$ \\
\hline Business and Management & Cert. III & 0.07 & $\begin{array}{l}0.02 \\
-\end{array}$ & $\begin{array}{l}0.06 \\
-\end{array}$ & $\begin{array}{l}0.22 \\
-\end{array}$ & $\begin{array}{l}0.12 \\
-\end{array}$ & $\begin{array}{l}0.16 \\
-\end{array}$ & $\begin{array}{l}0.16 \\
-\end{array}$ \\
\hline Business and Management & Cert. IV & $\begin{array}{l}0.06 \\
-\end{array}$ & $\begin{array}{l}0.35 \\
-\end{array}$ & 1.04 & $\begin{array}{l}0.51 \\
-\end{array}$ & $\begin{array}{l}0.61 \\
-\end{array}$ & $\begin{array}{l}0.11 \\
-\end{array}$ & $\begin{array}{l}0.27 \\
-\end{array}$ \\
\hline Business and Management & Diploma+ & 0.35 & 0.93 & 0.14 & 0.31 & 0.29 & $\begin{array}{l}0.33 \\
-\end{array}$ & $\begin{array}{l}0.25 \\
-\end{array}$ \\
\hline Civil Engineering & Cert. I & $\begin{array}{l}0.11 \\
-\end{array}$ & 0.03 & 0.16 & $\begin{array}{l}0.00 \\
-\end{array}$ & $\begin{array}{l}0.12 \\
-\end{array}$ & 0.06 & 0.03 \\
\hline Civil Engineering & Cert. II & 0.03 & $\begin{array}{l}0.46 \\
-\end{array}$ & $\begin{array}{l}0.04 \\
-\end{array}$ & 0.12 & $\begin{array}{l}0.09 \\
-\end{array}$ & $\begin{array}{l}0.13 \\
-\end{array}$ & $\begin{array}{l}0.01 \\
-\end{array}$ \\
\hline Civil Engineering & Cert. III & 0.03 & $\begin{array}{l}0.51 \\
-\end{array}$ & 0.08 & 0.03 & $\begin{array}{l}0.20 \\
-\end{array}$ & 0.31 & $\begin{array}{l}0.08 \\
-\end{array}$ \\
\hline Civil Engineering & Cert. IV & 0.16 & $\begin{array}{l}0.13 \\
-\end{array}$ & $\begin{array}{l}0.28 \\
-\end{array}$ & 0.60 & $\begin{array}{l}0.18 \\
-\end{array}$ & $\begin{array}{l}0.05 \\
-\end{array}$ & $\begin{array}{l}0.24 \\
-\end{array}$ \\
\hline Civil Engineering & Diploma+ & 0.56 & $\begin{array}{l}0.18 \\
-\end{array}$ & $\begin{array}{l}0.12 \\
-\end{array}$ & $\begin{array}{l}0.09 \\
-\end{array}$ & $\begin{array}{l}0.21 \\
-\end{array}$ & $\begin{array}{l}0.14 \\
-\end{array}$ & $\begin{array}{l}0.14 \\
-\end{array}$ \\
\hline Communication and Media Studies & Cert. I & $\begin{array}{l}0.24 \\
-\end{array}$ & $\begin{array}{l}0.14 \\
-\end{array}$ & $\begin{array}{l}0.06 \\
-\end{array}$ & $\begin{array}{l}0.13 \\
-\end{array}$ & $\begin{array}{l}0.22 \\
-\end{array}$ & $\begin{array}{l}0.10 \\
-\end{array}$ & $\begin{array}{l}0.36 \\
-\end{array}$ \\
\hline Communication and Media Studies & Cert. II & $\begin{array}{l}0.11 \\
-\end{array}$ & $\begin{array}{l}0.23 \\
-\end{array}$ & $\begin{array}{l}0.28 \\
-\end{array}$ & $\begin{array}{l}0.26 \\
-\end{array}$ & $\begin{array}{l}0.35 \\
-\end{array}$ & $\begin{array}{l}0.32 \\
-\end{array}$ & $\begin{array}{l}0.34 \\
-\end{array}$ \\
\hline Communication and Media Studies & Cert. III & $\begin{array}{l}0.30 \\
-\end{array}$ & $\begin{array}{l}0.17 \\
-\end{array}$ & $\begin{array}{l}0.35 \\
-\end{array}$ & $\begin{array}{l}0.13 \\
-\end{array}$ & $\begin{array}{l}0.19 \\
-\end{array}$ & $\begin{array}{l}0.14 \\
-\end{array}$ & $\begin{array}{l}0.45 \\
-\end{array}$ \\
\hline Communication and Media Studies & Cert. IV & $\begin{array}{l}0.08 \\
-\end{array}$ & $\begin{array}{l}0.94 \\
-\end{array}$ & $\begin{array}{l}0.58 \\
-\end{array}$ & $\begin{array}{l}0.19 \\
-\end{array}$ & 0.19 & $\begin{array}{l}0.46 \\
-\end{array}$ & $\begin{array}{l}0.66 \\
-\end{array}$ \\
\hline Communication and Media Studies & Diploma+ & $\begin{array}{l}0.89 \\
-\end{array}$ & 0.15 & $\begin{array}{l}0.17 \\
-\end{array}$ & $\begin{array}{l}0.40 \\
-\end{array}$ & $\begin{array}{l}0.52 \\
-\end{array}$ & $\begin{array}{l}0.89 \\
-\end{array}$ & $\begin{array}{l}0.95 \\
-\end{array}$ \\
\hline Complementary Therapies & Cert. I & $\begin{array}{l}0.10 \\
-\end{array}$ & $\begin{array}{l}0.04 \\
-\end{array}$ & $\begin{array}{l}0.21 \\
-\end{array}$ & $\begin{array}{l}0.18 \\
-\end{array}$ & $\begin{array}{l}0.07 \\
-\end{array}$ & $\begin{array}{l}0.18 \\
-\end{array}$ & $\begin{array}{l}0.08 \\
-\end{array}$ \\
\hline Complementary Therapies & Cert. II & 0.10 & 0.58 & $\begin{array}{l}0.24 \\
-\end{array}$ & $\begin{array}{l}0.09 \\
-\end{array}$ & $\begin{array}{l}0.20 \\
-\end{array}$ & 0.16 & $\begin{array}{l}0.02 \\
-\end{array}$ \\
\hline Complementary Therapies & Cert. III & 0.03 & 0.02 & 0.06 & 0.07 & 0.13 & 0.04 & 0.02 \\
\hline
\end{tabular}


Complementary Therapies

Complementary Therapies

Computer Science

Computer Science

Computer Science

Computer Science

Computer Science

Curriculum and Education Studies

Curriculum and Education Studies

Curriculum and Education Studies

Curriculum and Education Studies

Curriculum and Education Studies

Dental Studies

Dental Studies

Dental Studies

Dental Studies

Dental Studies

Earth Sciences

Earth Sciences

Earth Sciences

Earth Sciences

Earth Sciences

Electrical and Electronic Engineering and

Technology

Electrical and Electronic Engineering and

Technology

Electrical and Electronic Engineering and

Technology

Electrical and Electronic Engineering and

Technology

Electrical and Electronic Engineering and

Technology

Employment Skills Programmes

Employment Skills Programmes

Employment Skills Programmes

\begin{tabular}{|c|c|c|c|c|c|c|c|}
\hline Cert. IV & 0.05 & $\begin{array}{l}0.26 \\
-\end{array}$ & 0.11 & $\begin{array}{l}0.11 \\
-\end{array}$ & $\begin{array}{l}0.05 \\
-\end{array}$ & $\begin{array}{l}0.16 \\
-\end{array}$ & $\begin{array}{l}0.26 \\
-\end{array}$ \\
\hline \multirow[t]{2}{*}{ Diploma+ } & 0.78 & 0.68 & - & 0.30 & 0.12 & 0.24 & 0.31 \\
\hline & & & & & & & \\
\hline \multirow[t]{2}{*}{ Cert. I } & .03 & 0.04 & 0.10 & 0.13 & 0.12 & 0.22 & 0.05 \\
\hline & & 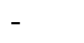 & & & . & - & 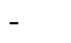 \\
\hline \multirow[t]{2}{*}{ Cert. II } & 13 & 0.29 & 0.03 & 0.49 & 0.19 & 0.15 & 0.21 \\
\hline & & & & & & & \\
\hline \multirow[t]{2}{*}{ Cert. III } & 0.32 & 0.26 & 0.44 & 0.64 & 0.45 & 0.13 & 0.07 \\
\hline & & - & 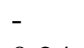 & - & - & & \\
\hline \multirow[t]{2}{*}{ Cert. IV } & 0.18 & 0.31 & 0.24 & 0.27 & 0.51 & 0.09 & 0.53 \\
\hline & & & - & 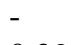 & & & \\
\hline \multirow[t]{2}{*}{ Diploma+ } & 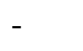 & - & 0.55 & 0.29 & - & - & - \\
\hline & - & & - & & - & & \\
\hline Cert. I & 0.29 & 0.04 & 0.12 & - & 0.63 & 0.70 & 0.25 \\
\hline \multirow[t]{2}{*}{ Cert. II } & .12 & 0.12 & 0.11 & 0.08 & 0.06 & 0.15 & 0.06 \\
\hline & - & & & - & - & - & - \\
\hline \multirow[t]{2}{*}{ Cert. III } & 0.01 & 0.79 & 0.01 & 0.12 & 0.13 & 0.81 & 0.73 \\
\hline & - & & & & - & & - \\
\hline \multirow[t]{2}{*}{ Cert. IV } & 0.46 & - & 0.75 & - & 0.25 & - & 0.29 \\
\hline & & & - & & - & - & - \\
\hline \multirow[t]{2}{*}{ Diploma+ } & - & - & 0.30 & - & 0.01 & 0.72 & 0.60 \\
\hline & - & & & - & & - & \\
\hline \multirow[t]{2}{*}{ Cert. I } & 0.40 & 0.17 & 0.38 & 0.11 & 0.17 & 0.14 & 0.02 \\
\hline & & - & & - & - & - & - \\
\hline \multirow[t]{2}{*}{ Cert. II } & 0.30 & 0.15 & 0.00 & 0.01 & 0.01 & 0.04 & 0.10 \\
\hline & & & - & - & - & & 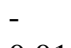 \\
\hline \multirow[t]{2}{*}{ Cert. III } & 0.02 & 0.00 & 0.05 & 0.11 & 0.13 & 0.09 & 0.01 \\
\hline & & - & - & , & . & - & - \\
\hline \multirow[t]{2}{*}{ Cert. IV } & 0.26 & 0.26 & 0.11 & 0.11 & 0.05 & 0.16 & 0.26 \\
\hline & & - & & - & - & - & - \\
\hline \multirow[t]{2}{*}{ Diploma+ } & 0.78 & 0.68 & & 0.30 & 0.12 & 0.24 & 0.31 \\
\hline & & - & & & - & & - \\
\hline \multirow[t]{2}{*}{ Cert. I } & 0.29 & 0.22 & 0.36 & 0.04 & 1.02 & 0.02 & 0.02 \\
\hline & & 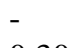 & & & 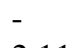 & & - \\
\hline \multirow[t]{2}{*}{ Cert. II } & 0.10 & 0.30 & 0.07 & 0.29 & 2.11 & 0.64 & 0.11 \\
\hline & & - & - & . & - & & - \\
\hline Cert. III & 0.74 & 0.43 & 0.24 & 0.06 & 0.04 & 0.01 & 0.17 \\
\hline & & & - & & 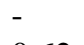 & - & \\
\hline Cert. IV & 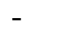 & - & 0.92 & - & 0.62 & 0.27 & 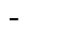 \\
\hline Diploma+ & - & 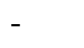 & - & - & - & - & - \\
\hline & & $\bar{\rho}$ & 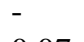 & - & & & \\
\hline Cert. I & 0.07 & 0.16 & 0.07 & 0.06 & 0.00 & 0.04 & 0.07 \\
\hline Cert. II & 0.33 & 0.13 & 0.32 & 0.59 & 0.23 & 0.40 & 0.03 \\
\hline Cert. III & 15 & 0.10 & 0 . & 0.12 & 0.08 & 0.10 & 0.15 \\
\hline & - & 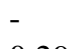 & 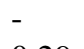 & 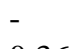 & - & 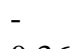 & - \\
\hline Cert. IV & 0.12 & 0.29 & 0.29 & 0.36 & 0.13 & 0.36 & 0.27 \\
\hline & - & 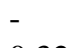 & 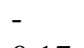 & 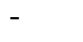 & . & 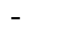 & \\
\hline Diploma+ & 0.22 & 0.32 & 0.17 & 0.44 & 0.28 & 0.13 & 0.05 \\
\hline & & - & . & - & - & - & 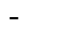 \\
\hline Cert. I & - & 0.51 & 0.26 & 0.49 & 0.61 & 0.13 & 0.16 \\
\hline & & - & - & & & & - \\
\hline Cert. II & 0.07 & 0.32 & 0.52 & 0.13 & 0.52 & 0.06 & 0.29 \\
\hline & - & & & & - & - & \\
\hline Cert. III & 0.11 & 1.47 & 0.25 & 0.06 & 0.38 & 0.48 & 0.02 \\
\hline
\end{tabular}


Employment Skills Programmes

Employment Skills Programmes

Environmental Studies

Environmental Studies

Environmental Studies

Environmental Studies

Environmental Studies

Fisheries Studies

Fisheries Studies

Fisheries Studies

Fisheries Studies

Fisheries Studies

Food and Hospitality

Food and Hospitality

Food and Hospitality

Food and Hospitality

Food and Hospitality

Forestry Studies

Forestry Studies

Forestry Studies

Forestry Studies

Forestry Studies

General Education Programmes

General Education Programmes

General Education Programmes

General Education Programmes

General Education Programmes

Geomatic Engineering

Geomatic Engineering

Geomatic Engineering $\begin{array}{llllllll}\text { Cert. IV } & \overline{0} .24 & \overline{0} .14 & \overline{0.27} & 0.45 & 0.18 & 0.33 & 0.15\end{array}$

$\begin{array}{llllllll}\text { Diploma+ } & 0.17 & 0.31 & 0.54 & 0.25 & 0.27 & 0.17 & 0.25\end{array}$

$\begin{array}{llllllll}\text { Cert. I } & 0.07 & 0.05 & 0.08 & 0.29 & 0.13 & 0.15 & 0.13\end{array}$

$\begin{array}{llllllll}\text { Cert. II } & 0.25 & 0.16 & 0.09 & 0.22 & 0.07 & 0.10 & 0.13\end{array}$

$\begin{array}{llllllll}\text { Cert. III } & 0.08 & 0.42 & 0.13 & 0.01 & 0.01 & 0.23 & 0.12\end{array}$

$\begin{array}{llllllll}\text { Cert. IV } & 0.03 & 0.10 & 0.15 & 0.65 & 0.11 & 0.19 & 0.26\end{array}$

$\begin{array}{llllllll} & - & - & & - & - & - & - \\ \text { Diploma+ } & 0.04 & 0.44 & 0.05 & 0.75 & 0.37 & 0.29 & 0.50\end{array}$

$\begin{array}{llllllll}\text { Cert. I } & 0.32 & 0.01 & 1.15 & 0.03 & 0.12 & 0.31 & 0.40\end{array}$

$\begin{array}{llllllll}\text { Cert. II } & 0.07 & 0.17 & 0.27 & 0.35 & 0.35 & 0.04 & 0.08\end{array}$

$\begin{array}{llllllll}\text { Cert. III } & 0.09 & 0.21 & 0.11 & 0.54 & 0.37 & 0.19 & 0.06\end{array}$

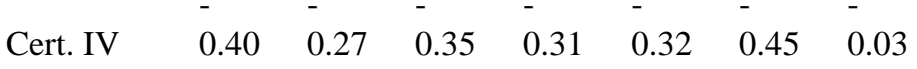

$\begin{array}{llllllll}\text { Diploma+ } & 0.26 & 0.27 & 0.50 & 0.01 & 0.18 & 0.28 & 0.46\end{array}$

$\begin{array}{llllllll}\text { Cert. I } & 0.22 & 0.07 & 0.11 & 0.21 & 0.03 & 0.29 & 0.03\end{array}$

$\begin{array}{llllllll}\text { Cert. II } & 0.06 & 0.11 & 0.07 & 0.18 & 0.02 & 0.14 & 0.03\end{array}$

$\begin{array}{llllllll}\text { Cert. III } & 0.06 & 0.06 & 0.10 & 0.12 & 0.13 & 0.10 & 0.14\end{array}$

$\begin{array}{llllllll}\text { Cert. IV } & 0.08 & 0.12 & 0.11 & 0.26 & 0.21 & 0.13 & 0.19\end{array}$

$\begin{array}{llllllll} & - & - & - & - & - & - & - \\ \text { Diploma+ } & 0.01 & 0.06 & 0.19 & 0.14 & 0.32 & 0.04 & 0.24\end{array}$

$\begin{array}{llllllll}\text { Cert. I } & 0.03 & 0.01 & 0.22 & 0.03 & 0.03 & 0.31 & 0.12\end{array}$

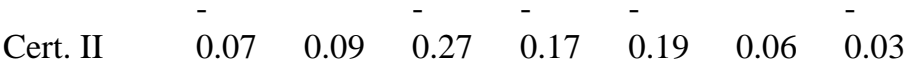

$\begin{array}{llllllll}\text { Cert. III } & 0.09 & 0.15 & 0.07 & 0.18 & 0.08 & 0.10 & 0.21\end{array}$

$\begin{array}{llllllll} & & - & - & & & & \\ \text { Cert. IV } & 0.05 & 0.18 & 0.15 & 0.14 & 0.14 & 0.14 & 0.09\end{array}$

$\begin{array}{llllllll}\text { Diploma+ } & 0.46 & 0.41 & 0.37 & 0.14 & 0.23 & 0.29 & 0.46\end{array}$

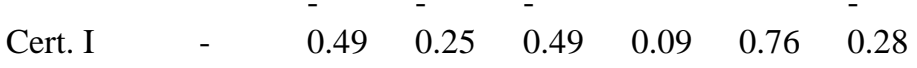

$\begin{array}{llllllll}\text { Cert. II } & 0.05 & 0.46 & 0.32 & 0.25 & 0.28 & 0.05 & 0.30\end{array}$

$\begin{array}{llllllll}\text { Cert. III } & \overline{0} & - & - & - & - & - & - \\ 0.44 & 0.14 & 0.13 & 0.14 & 0.11 & 0.16\end{array}$

$\begin{array}{llllllll}\text { Cert. IV } & 0.02 & 0.11 & 0.00 & 0.11 & 0.24 & 0.08 & 0.28\end{array}$

$\begin{array}{llllllll} & - & - & - & - & - & - & - \\ \text { Diploma+ } & 0.32 & 0.50 & 0.19 & 0.46 & 0.23 & 0.33 & 0.08\end{array}$

$\begin{array}{llllllll}\text { Cert. I } & 0.19 & 0.48 & 0.44 & 0.11 & 0.15 & 0.13 & 0.20\end{array}$

$\begin{array}{llllllll}\text { Cert. II } & 0.17 & 0.07 & 0.04 & 0.12 & 1.00 & 0.79 & 0.40\end{array}$

$\begin{array}{llllllll}\text { Cert. III } & 0.10 & 0.04 & 0.26 & 0.63 & 0.27 & 0.27 & 0.16\end{array}$ 
Geomatic Engineering

Geomatic Engineering

Graphic and Design Studies

Graphic and Design Studies

Graphic and Design Studies

Graphic and Design Studies

Graphic and Design Studies

Horticulture and Viticulture

Horticulture and Viticulture

Horticulture and Viticulture

Horticulture and Viticulture

Horticulture and Viticulture

Human Welfare Studies and Services

Human Welfare Studies and Services

Human Welfare Studies and Services

Human Welfare Studies and Services

Human Welfare Studies and Services

Information Systems

Information Systems

Information Systems

Information Systems

Information Systems

Justice and Law Enforcement

Justice and Law Enforcement

Justice and Law Enforcement

Justice and Law Enforcement

Justice and Law Enforcement

Language and Literature

Language and Literature

Language and Literature

\begin{tabular}{|c|c|c|c|c|c|c|c|}
\hline \multirow[t]{2}{*}{ Cert. IV } & 0.30 & 0.13 & 0.02 & 1.65 & 0.56 & 0.67 & 0.18 \\
\hline & - & - & - & - & - & - & - \\
\hline \multirow[t]{2}{*}{ Diploma+ } & 0.08 & 0.18 & 0.12 & 0.35 & 0.21 & 0.14 & 0.14 \\
\hline & & & & & - & 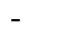 & - \\
\hline \multirow[t]{2}{*}{ Cert. I } & 0.00 & 0.09 & 0.10 & 0.16 & 0.22 & 0.05 & 0.21 \\
\hline & 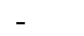 & - & 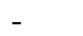 & 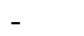 & - & - & - \\
\hline \multirow[t]{2}{*}{ Cert. II } & 0.10 & 0.02 & 0.28 & 0.21 & 0.24 & 0.29 & 0.28 \\
\hline & - & - & 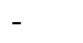 & - & - & 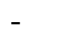 & - \\
\hline \multirow[t]{2}{*}{ Cert. III } & 0.17 & 0.18 & 0.31 & 0.41 & 0.41 & 0.03 & 0.38 \\
\hline & - & - & - & - & - & - & - \\
\hline \multirow[t]{2}{*}{ Cert. IV } & 0.02 & 0.08 & 0.37 & 0.24 & 0.71 & 0.38 & 0.47 \\
\hline & - & - & - & - & & - & - \\
\hline \multirow[t]{2}{*}{ Diploma+ } & 0.89 & 0.15 & 0.17 & 0.40 & 0.52 & 0.89 & 0.73 \\
\hline & - & & - & - & - & - & - \\
\hline \multirow[t]{2}{*}{ Cert. I } & 0.01 & 0.05 & 0.13 & 0.25 & 0.02 & 0.37 & 0.11 \\
\hline & - & & - & & - & & - \\
\hline \multirow[t]{2}{*}{ Cert. II } & 0.04 & 0.03 & 0.42 & 0.12 & 0.35 & 0.10 & 0.06 \\
\hline & & - & - & - & - & - & - \\
\hline \multirow[t]{2}{*}{ Cert. III } & 0.02 & 0.26 & 0.15 & 0.32 & 0.14 & 0.15 & 0.19 \\
\hline & - & - & - & - & - & 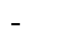 & - \\
\hline \multirow[t]{2}{*}{ Cert. IV } & 0.08 & 0.26 & 0.14 & 0.27 & 0.17 & 0.26 & 0.19 \\
\hline & - & - & - & - & - & & - \\
\hline \multirow[t]{2}{*}{ Diploma+ } & 0.19 & 0.59 & 0.51 & 0.31 & 0.54 & 0.30 & 0.60 \\
\hline & & - & - & - & - & - & - \\
\hline \multirow[t]{2}{*}{ Cert. I } & 0.02 & 0.04 & 0.02 & 0.18 & 0.02 & 0.03 & 0.06 \\
\hline & - & - & & - & & - & - \\
\hline \multirow[t]{2}{*}{ Cert. II } & 0.01 & 0.18 & 0.01 & 0.27 & 0.09 & 0.06 & 0.04 \\
\hline & & - & & - & - & 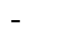 & - \\
\hline \multirow[t]{2}{*}{ Cert. III } & 0.05 & 0.12 & 0.03 & 0.08 & 0.03 & 0.02 & 0.05 \\
\hline & - & & - & 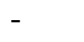 & - & & - \\
\hline \multirow[t]{2}{*}{ Cert. IV } & 0.18 & 0.20 & 0.92 & 0.22 & 0.29 & 0.05 & 0.38 \\
\hline & - & - & - & - & - & 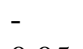 & \\
\hline Diploma+ & 0.15 & 0.20 & 0.05 & 0.29 & 0.36 & 0.05 & 0.34 \\
\hline & & - & - & - & - & 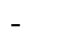 & - \\
\hline Cert. I & 0.10 & 0.16 & 0.07 & 0.14 & 0.06 & 0.02 & 0.01 \\
\hline & & - & - & - & & 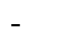 & - \\
\hline Cert. II & 0.00 & 0.19 & 0.19 & 0.11 & 0.04 & 0.09 & 0.16 \\
\hline & & - & - & - & - & 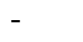 & - \\
\hline Cert. III & 0.08 & 0.25 & 0.27 & 0.26 & 0.21 & 0.25 & 0.28 \\
\hline & - & - & - & - & - & - & \\
\hline Cert. IV & 0.04 & 0.10 & 0.26 & 0.24 & 0.03 & 0.08 & 0.45 \\
\hline & & & - & 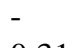 & & & \\
\hline Diploma+ & - & - & 0.56 & 0.31 & - & - & - \\
\hline & & - & & - & - & & - \\
\hline Cert. I & 0.07 & 0.14 & 0.04 & 0.12 & 0.09 & 0.03 & 0.22 \\
\hline & & - & & & & & - \\
\hline ert. II & 0.06 & 0.15 & 0.07 & 0.07 & 0.15 & 0.06 & 0.06 \\
\hline & & - & & & ก0? & & \\
\hline ert. III & 0.05 & 0.16 & 0.02 & 0.03 & 0.22 & 0.10 & 0. \\
\hline ert. IV & 0 & 7 & & 0 & & 005 & \\
\hline & - & - & - & - & - & - & \\
\hline Diploma+ & 0.15 & 0.20 & 0.05 & 0.29 & 0.36 & 0.05 & 0.34 \\
\hline & - & & & - & - & & \\
\hline Cert. I & 0.22 & 0.14 & 0.18 & 0.47 & 0.41 & 0.17 & 0.16 \\
\hline & - & - & & & - & - & - \\
\hline Cert. II & 0.45 & 0.52 & 0.02 & 0.22 & 0.05 & 0.05 & 0.65 \\
\hline & - & - & 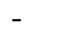 & - & - & & - \\
\hline ert. III & 0.28 & 0.25 & 0.14 & 0.08 & 0.10 & 0.14 & 0.1 \\
\hline
\end{tabular}




\begin{tabular}{|c|c|c|c|c|c|c|c|c|}
\hline Language and Literature & Cert. IV & $\begin{array}{l}0.03 \\
-\end{array}$ & $\begin{array}{l}0.06 \\
-\end{array}$ & 0.08 & $\begin{array}{l}0.11 \\
-\end{array}$ & $\begin{array}{l}0.00 \\
-\end{array}$ & 0.23 & 0.00 \\
\hline Language and Literature & Diploma+ & 0.04 & 0.18 & 0.02 & 0.21 & 0.26 & 0.11 & 0.33 \\
\hline Law & Cert. I & $\begin{array}{l}0.38 \\
-\end{array}$ & $\begin{array}{l}0.16 \\
-\end{array}$ & $\begin{array}{l}0.01 \\
-\end{array}$ & $\begin{array}{l}0.34 \\
-\end{array}$ & $\begin{array}{l}0.04 \\
-\end{array}$ & 0.06 & $\begin{array}{l}0.10 \\
-\end{array}$ \\
\hline Law & Cert. II & 0.06 & $\begin{array}{l}0.12 \\
-\end{array}$ & $\begin{array}{l}0.16 \\
-\end{array}$ & $\begin{array}{l}0.56 \\
-\end{array}$ & 0.18 & $\begin{array}{l}0.02 \\
-\end{array}$ & $\begin{array}{l}0.07 \\
-\end{array}$ \\
\hline Law & Cert. III & $\begin{array}{l}0.03 \\
-\end{array}$ & 0.11 & $\begin{array}{l}0.01 \\
-\end{array}$ & $\begin{array}{l}0.08 \\
-\end{array}$ & $\begin{array}{l}0.05 \\
-\end{array}$ & $\begin{array}{l}0.03 \\
-\end{array}$ & $\begin{array}{l}0.08 \\
-\end{array}$ \\
\hline Law & Cert. IV & 0.18 & $\begin{array}{l}0.07 \\
-\end{array}$ & 0.17 & 0.22 & 0.16 & $\begin{array}{l}0.05 \\
-\end{array}$ & 0.31 \\
\hline $\begin{array}{l}\text { Law } \\
\text { Librarianship, Information Management }\end{array}$ & Diploma+ & 0.15 & $\begin{array}{l}0.20 \\
-\end{array}$ & 0.05 & 0.29 & $\begin{array}{l}0.36 \\
-\end{array}$ & 0.05 & 0.34 \\
\hline $\begin{array}{l}\text { and Curatorial Studies } \\
\text { Librarianship, Information Management }\end{array}$ & Cert. I & 0.23 & 0.11 & $\begin{array}{l}0.03 \\
-\end{array}$ & $\begin{array}{l}0.06 \\
-\end{array}$ & 0.08 & $\begin{array}{l}0.01 \\
-\end{array}$ & $\begin{array}{l}0.14 \\
-\end{array}$ \\
\hline $\begin{array}{l}\text { and Curatorial Studies } \\
\text { Librarianship, Information Management }\end{array}$ & Cert. II & 0.34 & 0.12 & $\begin{array}{l}0.33 \\
-\end{array}$ & $\begin{array}{l}0.20 \\
-\end{array}$ & $\begin{array}{l}0.03 \\
-\end{array}$ & 0.02 & $\begin{array}{l}0.24 \\
-\end{array}$ \\
\hline $\begin{array}{l}\text { and Curatorial Studies } \\
\text { Librarianship, Information Management }\end{array}$ & Cert. III & 0.03 & $\begin{array}{l}0.06 \\
-\end{array}$ & 0.54 & 0.14 & 0.24 & $\begin{array}{l}0.24 \\
-\end{array}$ & 0.33 \\
\hline $\begin{array}{l}\text { and Curatorial Studies } \\
\text { Librarianship, Information Management }\end{array}$ & Cert. IV & $\begin{array}{l}0.13 \\
-\end{array}$ & $\begin{array}{l}0.80 \\
-\end{array}$ & $\begin{array}{l}0.22 \\
-\end{array}$ & $\begin{array}{l}0.18 \\
-\end{array}$ & $\begin{array}{l}0.06 \\
-\end{array}$ & $\begin{array}{l}0.57 \\
-\end{array}$ & 0.31 \\
\hline $\begin{array}{l}\text { and Curatorial Studies } \\
\text { Manufacturing Engineering and }\end{array}$ & Diploma+ & 0.15 & $\begin{array}{l}0.20 \\
-\end{array}$ & 0.05 & $\begin{array}{l}0.29 \\
-\end{array}$ & $\begin{array}{l}0.36 \\
-\end{array}$ & $\begin{array}{l}0.05 \\
-\end{array}$ & 0.34 \\
\hline $\begin{array}{l}\text { Technology } \\
\text { Manufacturing Engineering and }\end{array}$ & Cert. I & 0.00 & $\begin{array}{l}0.18 \\
-\end{array}$ & 0.09 & 0.12 & 0.23 & 0.08 & 0.13 \\
\hline $\begin{array}{l}\text { Technology } \\
\text { Manufacturin }\end{array}$ & Cert. II & 0.09 & $\begin{array}{l}0.30 \\
-\end{array}$ & $\begin{array}{l}0.17 \\
-\end{array}$ & $\begin{array}{l}0.42 \\
-\end{array}$ & 0.04 & & $\begin{array}{l}0.03 \\
-\end{array}$ \\
\hline $\begin{array}{l}\text { Technology } \\
\text { Manufacturing Engineering and }\end{array}$ & Cert. III & 0.11 & $\begin{array}{l}0.23 \\
-\end{array}$ & $\begin{array}{l}0.20 \\
-\end{array}$ & $\begin{array}{l}0.27 \\
-\end{array}$ & $\begin{array}{l}0.17 \\
-\end{array}$ & $\begin{array}{l}0.11 \\
-\end{array}$ & $\begin{array}{l}0.21 \\
-\end{array}$ \\
\hline $\begin{array}{l}\text { Technology } \\
\text { Manufacturing Engineering and }\end{array}$ & Cert. IV & & $\begin{array}{l}0.06 \\
-\end{array}$ & 0.21 & $\begin{array}{l}0.35 \\
-\end{array}$ & 0.52 & $\begin{array}{l}0.19 \\
-\end{array}$ & 0.29 \\
\hline Tech & Diploma+ & 0.07 & $\begin{array}{l}0.35 \\
-\end{array}$ & 0.09 & $\begin{array}{l}0.59 \\
-\end{array}$ & 0.06 & $\begin{array}{l}0.10 \\
-\end{array}$ & $\begin{array}{l}0.15 \\
-\end{array}$ \\
\hline Maritime Engineering and Technology & Cert. I & 0.03 & $\begin{array}{l}0.13 \\
-\end{array}$ & 0.05 & $\begin{array}{l}0.02 \\
-\end{array}$ & 0.08 & 0.04 & 1.34 \\
\hline Maritime Engineering and Technology & Cert. II & 0.43 & 0.07 & 0.08 & $\begin{array}{l}0.12 \\
-\end{array}$ & $\begin{array}{l}0.31 \\
-\end{array}$ & 0.40 & 0.78 \\
\hline Maritime Engineering and Technology & Cert. III & 0.09 & 0.14 & $\begin{array}{l}0.09 \\
-\end{array}$ & 0.20 & 0.15 & $\begin{array}{l}0.00 \\
-\end{array}$ & $\begin{array}{l}0.12 \\
-\end{array}$ \\
\hline ing and Technology & Cert. & 0.27 & $\begin{array}{l}0.08 \\
-\end{array}$ & $\begin{array}{l}0.05 \\
-\end{array}$ & $\begin{array}{l}0.02 \\
-\end{array}$ & $\begin{array}{l}0.01 \\
-\end{array}$ & $\begin{array}{l}0.20 \\
-\end{array}$ & 0.03 \\
\hline $\begin{array}{l}\text { Maritime Engineering and Technology } \\
\text { Mechanical and Industrial Engineering }\end{array}$ & Diploma+ & 0.15 & 0.28 & $\begin{array}{l}0.16 \\
-\end{array}$ & 0.31 & 0.42 & $\begin{array}{l}0.06 \\
-\end{array}$ & 0.00 \\
\hline $\begin{array}{l}\text { and Technology } \\
\text { Mechanical and Industrial Engineering }\end{array}$ & Cert. I & 0.03 & 0.16 & 0.12 & 0.22 & 0.01 & 0.11 & 0.05 \\
\hline $\begin{array}{l}\text { and Technology } \\
\text { Mechanical and Industrial Engineering }\end{array}$ & Cert. II & 0.26 & 0.20 & 0.09 & 0.19 & 0.12 & 0.23 & 0.15 \\
\hline and Technolc & Cert. III & 0.13 & 0.06 & 0.03 & 0.06 & 0.03 & 0.02 & 0.09 \\
\hline $\begin{array}{l}\text { Mechanical and Industrial Engineering } \\
\text { and Technology }\end{array}$ & Cert. IV & $-\overline{0}$ & $-\overline{0}-22$ & $-\overline{0}-06$ & $-\overline{0}-26$ & $-\overline{0}-20$ & - & $-\overline{0}-21$ \\
\hline $\begin{array}{l}\text { Mechanical and Industrial Engineering } \\
\text { and Technology }\end{array}$ & Diploma+ & $\begin{array}{l}- \\
0.06 \\
-\end{array}$ & 0.07 & $\overline{-}-04$ & $-\overline{0}$ & $\begin{array}{l}- \\
0.20 \\
-\end{array}$ & - & $\overline{-}-15$ \\
\hline Medical Studies & Cert. I & $\begin{array}{l}0.05 \\
-\end{array}$ & 0.04 & 0.04 & 0.03 & 0.23 & 0.06 & 0.06 \\
\hline Medical Studies & Cert. II & 0.08 & 0.07 & 0.07 & $\begin{array}{l}0.06 \\
-\end{array}$ & 0.16 & 0.01 & 0.12 \\
\hline Medical Studies & Cert. III & 0.03 & 0.02 & 0.06 & 0.07 & 0.13 & 0.04 & 0.02 \\
\hline
\end{tabular}




\begin{tabular}{|c|c|c|c|c|c|c|c|c|}
\hline Medical Studies & Cert. IV & 0.05 & $\begin{array}{l}0.26 \\
-\end{array}$ & 0.11 & $\begin{array}{l}0.11 \\
-\end{array}$ & $\begin{array}{l}0.05 \\
-\end{array}$ & $\begin{array}{l}0.16 \\
-\end{array}$ & $\begin{array}{l}0.26 \\
-\end{array}$ \\
\hline Medical Studies & Diploma+ & 0.78 & $\begin{array}{l}0.68 \\
-\end{array}$ & - & 0.30 & 0.12 & 0.24 & 0.31 \\
\hline Nursing & Cert. I & 0.33 & 0.06 & 0.15 & 0.09 & 0.09 & 0.11 & 0.10 \\
\hline Nursing & Cert. II & $\begin{array}{l}0.19 \\
-\end{array}$ & 0.11 & 0.13 & $\begin{array}{l}0.14 \\
-\end{array}$ & $\begin{array}{l}0.09 \\
-\end{array}$ & 0.20 & $\begin{array}{l}0.17 \\
-\end{array}$ \\
\hline Nursing & Cert. III & 0.55 & $\begin{array}{l}0.02 \\
-\end{array}$ & $\begin{array}{l}1.03 \\
-\end{array}$ & $\begin{array}{l}0.07 \\
-\end{array}$ & $\begin{array}{l}0.13 \\
-\end{array}$ & $\begin{array}{l}0.04 \\
-\end{array}$ & $\begin{array}{l}0.23 \\
-\end{array}$ \\
\hline Nursing & Cert. IV & 0.05 & $\begin{array}{l}0.13 \\
-\end{array}$ & 0.31 & $\begin{array}{l}0.45 \\
-\end{array}$ & $\begin{array}{l}0.50 \\
-\end{array}$ & $\begin{array}{l}0.16 \\
-\end{array}$ & $\begin{array}{l}0.26 \\
-\end{array}$ \\
\hline Nursing & Diploma+ & 0.78 & 0.68 & - & $\begin{array}{l}0.30 \\
-\end{array}$ & $\begin{array}{l}0.12 \\
-\end{array}$ & 0.24 & $\begin{array}{l}0.31 \\
-\end{array}$ \\
\hline Office Studies & Cert. I & 0.09 & $\begin{array}{l}0.04 \\
-\end{array}$ & $\begin{array}{l}0.05 \\
-\end{array}$ & $\begin{array}{l}0.03 \\
-\end{array}$ & $\begin{array}{l}0.01 \\
-\end{array}$ & $\begin{array}{l}0.01 \\
-\end{array}$ & 0.03 \\
\hline Office Studies & Cert. II & 0.21 & $\begin{array}{l}0.02 \\
-\end{array}$ & $\begin{array}{l}0.04 \\
-\end{array}$ & $\begin{array}{l}0.07 \\
-\end{array}$ & $\begin{array}{l}0.03 \\
-\end{array}$ & $\begin{array}{l}0.07 \\
-\end{array}$ & $\begin{array}{l}0.32 \\
-\end{array}$ \\
\hline Office Studies & Cert. III & $\begin{array}{l}0.00 \\
-\end{array}$ & $\begin{array}{l}0.13 \\
-\end{array}$ & $\begin{array}{l}0.11 \\
-\end{array}$ & $\begin{array}{l}0.17 \\
-\end{array}$ & $\begin{array}{l}0.17 \\
-\end{array}$ & $\begin{array}{l}0.15 \\
-\end{array}$ & $\begin{array}{l}0.15 \\
-\end{array}$ \\
\hline Office Studies & Cert. IV & $\begin{array}{l}0.03 \\
-\end{array}$ & $\begin{array}{l}0.14 \\
-\end{array}$ & $\begin{array}{l}0.10 \\
-\end{array}$ & $\begin{array}{l}0.25 \\
-\end{array}$ & $\begin{array}{l}0.20 \\
-\end{array}$ & $\begin{array}{l}0.22 \\
-\end{array}$ & $\begin{array}{l}0.28 \\
-\end{array}$ \\
\hline Office Studies & Diploma+ & $\begin{array}{l}0.03 \\
-\end{array}$ & 0.23 & 0.24 & 0.40 & 0.30 & 0.38 & 0.23 \\
\hline Optical Science & Cert. I & 0.05 & 0.04 & $\begin{array}{l}0.02 \\
-\end{array}$ & $\begin{array}{l}0.03 \\
-\end{array}$ & 0.11 & 0.06 & 0.06 \\
\hline Optical Science & Cert. II & 0.25 & 0.38 & $\begin{array}{l}0.02 \\
-\end{array}$ & $\begin{array}{l}0.02 \\
-\end{array}$ & $\begin{array}{l}0.29 \\
-\end{array}$ & 0.11 & $\begin{array}{l}0.09 \\
-\end{array}$ \\
\hline Optical Science & Cert. III & 0.03 & $\begin{array}{l}0.02 \\
-\end{array}$ & $\begin{array}{l}0.06 \\
-\end{array}$ & $\begin{array}{l}0.07 \\
-\end{array}$ & $\begin{array}{l}0.47 \\
-\end{array}$ & $\begin{array}{l}0.04 \\
-\end{array}$ & $\begin{array}{l}0.02 \\
-\end{array}$ \\
\hline Optical Science & Cert. IV & 0.05 & $\begin{array}{l}0.26 \\
-\end{array}$ & 0.11 & $\begin{array}{l}0.11 \\
-\end{array}$ & $\begin{array}{l}0.05 \\
-\end{array}$ & $\begin{array}{l}0.16 \\
-\end{array}$ & $\begin{array}{l}0.26 \\
-\end{array}$ \\
\hline $\begin{array}{l}\text { Optical Science } \\
\text { Other Agriculture, Environmental and }\end{array}$ & Diploma+ & 0.78 & 0.68 & - & $\begin{array}{l}0.30 \\
-\end{array}$ & $\begin{array}{l}0.12 \\
-\end{array}$ & $\begin{array}{l}0.24 \\
-\end{array}$ & $\begin{array}{l}0.31 \\
-\end{array}$ \\
\hline $\begin{array}{l}\text { Related Studies } \\
\text { Other Agriculture, Environmental and }\end{array}$ & Cert. I & & $\begin{array}{l}0.01 \\
-\end{array}$ & 0.18 & $\begin{array}{l}0.03 \\
-\end{array}$ & $\begin{array}{l}0.03 \\
-\end{array}$ & $\begin{array}{l}0.31 \\
-\end{array}$ & $\begin{array}{l}0.12 \\
-\end{array}$ \\
\hline $\begin{array}{l}\text { Related Studies } \\
\text { Other Agriculture, Environmental and }\end{array}$ & Cert. II & $\begin{array}{l}0.07 \\
-\end{array}$ & $\begin{array}{l}0.17 \\
-\end{array}$ & 0.27 & & 0.19 & $\begin{array}{l}0.04 \\
-\end{array}$ & $\begin{array}{l}0.16 \\
-\end{array}$ \\
\hline Related Studies & Cert. III & 0.07 & 0.03 & 0.07 & 0.24 & 0.32 & 0.51 & 0.19 \\
\hline $\begin{array}{l}\text { Other Agriculture, Environmental and } \\
\text { Related Studies }\end{array}$ & Cert. IV & $-\overline{0}-49$ & $-\overline{0}-73$ & $\overline{-}-40$ & $\overline{-}-34$ & $-\overline{0}-3$ & $-\overline{0}$ & - \\
\hline Other Agriculture, Environmental and & & - & - & - & - & - & - & - \\
\hline Related Studies & Diploma+ & 0.10 & $\begin{array}{l}0.42 \\
-\end{array}$ & $\begin{array}{l}0.37 \\
-\end{array}$ & $\begin{array}{l}0.14 \\
-\end{array}$ & $\begin{array}{l}0.23 \\
-\end{array}$ & $\begin{array}{l}0.29 \\
-\end{array}$ & $\begin{array}{l}0.46 \\
-\end{array}$ \\
\hline Other Creative Arts & Cert. I & $\begin{array}{l}0.39 \\
-\end{array}$ & $\begin{array}{l}0.13 \\
-\end{array}$ & $\begin{array}{l}0.42 \\
-\end{array}$ & $\begin{array}{l}0.18 \\
-\end{array}$ & $\begin{array}{l}0.22 \\
-\end{array}$ & $\begin{array}{l}0.14 \\
-\end{array}$ & $\begin{array}{l}0.26 \\
-\end{array}$ \\
\hline Other Creative Arts & Cert. II & $\begin{array}{l}0.19 \\
-\end{array}$ & $\begin{array}{l}0.38 \\
-\end{array}$ & $\begin{array}{l}0.77 \\
-\end{array}$ & $\begin{array}{l}0.12 \\
-\end{array}$ & $\begin{array}{l}1.55 \\
-\end{array}$ & $\begin{array}{l}0.51 \\
-\end{array}$ & $\begin{array}{l}0.31 \\
-\end{array}$ \\
\hline Other Creative Arts & Cert. III & $\begin{array}{l}0.06 \\
-\end{array}$ & $\begin{array}{l}0.16 \\
-\end{array}$ & $\begin{array}{l}0.24 \\
-\end{array}$ & 0.15 & 0.29 & $\begin{array}{l}0.18 \\
-\end{array}$ & $\begin{array}{l}0.37 \\
-\end{array}$ \\
\hline Other Creative Arts & Cert. IV & $\begin{array}{l}0.48 \\
-\end{array}$ & $\begin{array}{l}0.46 \\
-\end{array}$ & $\begin{array}{l}0.16 \\
-\end{array}$ & $\begin{array}{l}0.51 \\
-\end{array}$ & 0.66 & $\begin{array}{l}0.70 \\
-\end{array}$ & $\begin{array}{l}0.47 \\
-\end{array}$ \\
\hline Other Creative Arts & Diploma+ & $\begin{array}{l}0.89 \\
-\end{array}$ & $\begin{array}{l}0.15 \\
-\end{array}$ & $\begin{array}{l}0.17 \\
-\end{array}$ & 0.40 & $\begin{array}{l}0.52 \\
-\end{array}$ & 0.89 & 0.73 \\
\hline Other Education & Cert. I & 0.29 & 0.98 & 0.12 & - & 0.88 & 0.70 & 0.24 \\
\hline Other Education & Cert. II & $\begin{array}{l}0.17 \\
-\end{array}$ & 0.16 & 0.11 & $\begin{array}{l}0.09 \\
-\end{array}$ & $\begin{array}{l}0.10 \\
-\end{array}$ & $\begin{array}{l}0.16 \\
-\end{array}$ & $\begin{array}{l}0.08 \\
-\end{array}$ \\
\hline Other Education & Cert. III & 0.04 & 0.08 & 0.15 & 0.27 & 0.32 & 0.48 & 0.25 \\
\hline
\end{tabular}


Other Education

Other Education

Other Engineering and Related

Technologies

Other Engineering and Related

Technologies

Other Engineering and Related

Technologies

Other Engineering and Related

Technologies

Other Engineering and Related

Technologies

Other Health

Other Health

Other Health

Other Health

Other Health

Other Information Technology

Other Information Technology

Other Information Technology

Other Information Technology

Other Information Technology

Other Management and Commerce

Other Management and Commerce

Other Management and Commerce

Other Management and Commerce

Other Management and Commerce

Other Mixed Field Programmes

Other Mixed Field Programmes

Other Mixed Field Programmes

Other Mixed Field Programmes

Other Mixed Field Programmes

Other Natural and Physical Sciences

Other Natural and Physical Sciences

Other Natural and Physical Sciences

\begin{tabular}{|c|c|c|c|c|c|c|c|}
\hline Cert. IV & 0.46 & - & $\begin{array}{l}0.75 \\
-\end{array}$ & - & 0.25 & - & 0.29 \\
\hline \multirow[t]{2}{*}{ Diploma+ } & - & - & 0.31 & - & 0.07 & 0.96 & - \\
\hline & & - & & & & 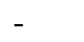 & \\
\hline \multirow[t]{2}{*}{ Cert. I } & 0.10 & 0.19 & 0.06 & 0.29 & 0.11 & 0.04 & 0.36 \\
\hline & & & & & & & \\
\hline \multirow[t]{2}{*}{ Cert. II } & 0.28 & 0.47 & 0.13 & 0.40 & 0.13 & 0.25 & 0.20 \\
\hline & & & - & & 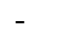 & - & - \\
\hline \multirow[t]{2}{*}{ Cert. III } & 0.29 & 0.00 & 0.08 & 0.41 & 0.27 & 0.16 & 0.04 \\
\hline & & & & & - & & 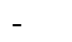 \\
\hline \multirow[t]{2}{*}{ Cert. IV } & 0.04 & 0.18 & 0.26 & 0.29 & 0.05 & 0.00 & 0.20 \\
\hline & & - & 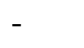 & & - & - & - \\
\hline \multirow[t]{2}{*}{ Diploma+ } & 1.00 & 0.18 & 0.12 & 0.35 & 0.21 & 0.14 & 0.14 \\
\hline & - & - & & 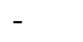 & - & & - \\
\hline \multirow[t]{2}{*}{ Cert. I } & 0.05 & 0.24 & 0.04 & 0.31 & 0.15 & 0.06 & 0.20 \\
\hline & - & & & & - & - & - \\
\hline \multirow[t]{2}{*}{ Cert. II } & 0.75 & 0.07 & 0.22 & 0.06 & 0.12 & 0.34 & 0.13 \\
\hline & & . & & & - & & \\
\hline \multirow[t]{2}{*}{ Cert. III } & 0.09 & 0.01 & 0.06 & 0.16 & 0.16 & 0.04 & 0.03 \\
\hline & & - & 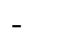 & & - & 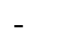 & \\
\hline \multirow[t]{2}{*}{ Cert. IV } & 0.05 & 0.26 & 0.11 & 0.11 & 0.05 & 0.16 & 0.26 \\
\hline & & - & & - & - & - & - \\
\hline \multirow[t]{2}{*}{ Diploma+ } & 0.78 & 0.68 & - & 0.30 & 0.12 & 0.24 & 0.31 \\
\hline & & - & & & - & & 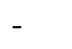 \\
\hline \multirow[t]{2}{*}{ Cert. I } & 0.10 & 0.88 & 0.16 & 0.11 & 0.10 & 0.78 & 0.07 \\
\hline & - & & & 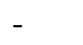 & - & - & \\
\hline \multirow[t]{2}{*}{ Cert. II } & 0.17 & 0.02 & 0.11 & 0.23 & 0.33 & 0.21 & 0.15 \\
\hline & 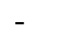 & - & 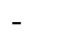 & & & - & \\
\hline \multirow[t]{2}{*}{ Cert. III } & 0.08 & 0.24 & 0.35 & 0.34 & 0.25 & 0.22 & 0.27 \\
\hline & - & - & - & & 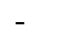 & - & \\
\hline \multirow[t]{2}{*}{ Cert. IV } & 0.25 & 0.12 & 0.24 & 0.23 & 0.47 & 0.57 & 0.56 \\
\hline & & & - & & & & \\
\hline Diploma+ & - & - & 0.55 & 0.29 & - & - & - \\
\hline & & - & - & & & & \\
\hline Cert. I & 0.44 & 0.11 & 0.05 & 0.45 & 0.06 & 0.04 & 0.59 \\
\hline & & - & - & 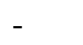 & - & - & - \\
\hline Cert. II & 0.02 & 0.02 & 0.04 & 0.07 & 0.35 & 0.11 & 0.09 \\
\hline & 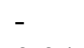 & - & . & & 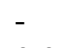 & - & - \\
\hline Cert. III & 0.04 & 0.07 & 0.06 & 0.12 & 0.09 & 0.10 & 0.15 \\
\hline & - & - & - & & - & & - \\
\hline Cert. IV & 0.04 & 0.07 & 0.06 & 0.06 & 0.27 & 0.63 & 0.27 \\
\hline & & - & - & & 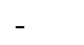 & 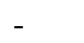 & \\
\hline Diploma+ & 0.08 & 1.44 & 2.40 & 0.15 & 0.29 & 0.48 & 0.28 \\
\hline & & - & - & 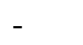 & - & & \\
\hline Cert. I & - & 0.49 & 0.25 & 0.48 & 0.23 & 0.17 & 0.38 \\
\hline & & - & - & 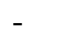 & - & & \\
\hline Cert. II & 0.07 & 0.44 & 0.30 & 0.23 & 0.26 & 0.69 & 0.54 \\
\hline & & - & - & - & - & - & - \\
\hline Cert. III & 0.22 & 0.11 & 0.29 & 0.09 & 0.56 & 0.17 & 0.13 \\
\hline & - & - & & 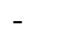 & - & & - \\
\hline Cert. IV & 0.04 & 0.03 & 0.01 & 0.23 & 0.12 & 0.49 & 0.14 \\
\hline & - & - & - & . & . & - & - \\
\hline Diploma+ & 0.25 & 0.39 & 1.81 & 0.27 & 0.45 & 0.82 & 0.21 \\
\hline & & - & - & - & - & & 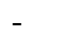 \\
\hline Cert. I & 0.29 & 0.63 & 0.23 & 0.08 & 0.11 & 0.12 & 0.02 \\
\hline & & - & - & - & - & - & - \\
\hline Cert. II & 0.25 & 0.30 & 0.07 & 0.31 & 0.15 & 0.04 & 0.31 \\
\hline & & - & & 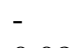 & - & & \\
\hline Cert. III & 0.31 & 0.36 & 0.06 & 0.08 & 0.06 & 0.00 & 0.02 \\
\hline
\end{tabular}


Other Natural and Physical Sciences

Other Natural and Physical Sciences

Other Society and Culture

Other Society and Culture

Other Society and Culture

Other Society and Culture

Other Society and Culture

Performing Arts

Performing Arts

Performing Arts

Performing Arts

Performing Arts

Personal Services

Personal Services

Personal Services

Personal Services

Personal Services

Political Science and Policy Studies

Political Science and Policy Studies

Political Science and Policy Studies

Political Science and Policy Studies

Political Science and Policy Studies

Process and Resources Engineering

Process and Resources Engineering

Process and Resources Engineering

Process and Resources Engineering

Process and Resources Engineering

Public Health

Public Health

Public Health

Public Health

\begin{tabular}{|c|c|c|c|c|c|c|c|}
\hline & & & & & & & \\
\hline Cert. IV & - & - & 0.94 & - & 0.64 & 0.28 & - \\
\hline Diploma+ & - & - & - & - & - & - & - \\
\hline & & _ & & . & - & & . \\
\hline Cert. I & 0.04 & 0.05 & 0.00 & 0.15 & 0.03 & 0.00 & 0.10 \\
\hline & . & - & - & . & & . & . \\
\hline Cert. II & 0.06 & 0.12 & 0.03 & 0.20 & 0.01 & 0.02 & 0.07 \\
\hline & & & 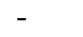 & & & & \\
\hline Cert. III & 0.42 & 0.05 & 0.25 & 0.00 & 0.05 & 0.03 & 0.08 \\
\hline & & & & 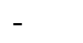 & - & - & - \\
\hline Cert. IV & 0.03 & 0.30 & 0.11 & 0.10 & 0.16 & 0.05 & 0.31 \\
\hline & - & - & & - & - & - & \\
\hline Diploma+ & 0.15 & 0.20 & 0.53 & 0.29 & 0.36 & 0.05 & 0.34 \\
\hline & - & - & - & - & - & - & - \\
\hline Cert. I & 0.06 & 0.24 & 0.07 & 0.19 & 0.22 & 0.11 & 0.33 \\
\hline & - & - & - & 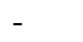 & - & - & . \\
\hline Cert. II & 0.43 & 0.78 & 0.20 & 0.13 & 0.31 & 0.31 & 0.37 \\
\hline & - & - & - & 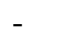 & - & - & 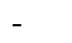 \\
\hline Cert. III & 0.06 & 0.19 & 0.16 & 0.10 & 0.25 & 0.30 & 0.34 \\
\hline & - & - & - & 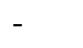 & - & - & 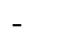 \\
\hline Cert. IV & 0.20 & 0.47 & 0.25 & 0.07 & 0.27 & 0.37 & 0.53 \\
\hline & - & - & - & - & & - & - \\
\hline Diploma+ & 0.97 & 1.09 & 0.04 & 0.45 & 0.52 & 0.49 & 0.73 \\
\hline Cert. I & 0.22 & 0.00 & 0.00 & 0.18 & 0.02 & 0.28 & 0.03 \\
\hline & & - & & - & - & - & - \\
\hline Cert. II & 0.12 & 0.32 & 0.02 & 0.16 & 0.17 & 0.25 & 0.21 \\
\hline & - & - & - & 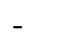 & - & - & - \\
\hline Cert. III & 0.08 & 0.18 & 0.20 & 0.22 & 0.19 & 0.17 & 0.20 \\
\hline & - & - & - & - & - & - & - \\
\hline Cert. IV & 0.16 & 0.24 & 0.22 & 0.32 & 0.29 & 0.19 & 0.31 \\
\hline & & & - & - & - & - & - \\
\hline Diploma+ & 0.54 & 0.34 & 0.54 & 0.77 & 0.05 & 0.04 & 0.24 \\
\hline & & & & - & - & & 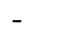 \\
\hline Cert. I & 0.04 & 0.40 & 0.50 & 0.15 & 0.03 & 0.00 & 0.10 \\
\hline Cert. II & 0.21 & 0.05 & 0.21 & 0.28 & 0.05 & 0.10 & 0.07 \\
\hline & & & - & 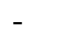 & - & - & - \\
\hline Cert. III & 0.03 & 0.67 & 0.12 & 0.49 & 0.04 & 0.22 & 0.04 \\
\hline & - & - & - & & - & - & - \\
\hline Cert. IV & 0.01 & 0.01 & 0.71 & 0.14 & 0.16 & 0.05 & 0.31 \\
\hline & - & - & - & 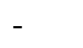 & - & - & \\
\hline Diploma+ & 0.15 & 0.20 & 0.05 & 0.29 & 0.36 & 0.05 & 0.34 \\
\hline & & - & & . & & . & - \\
\hline Cert. I & 0.25 & 0.46 & 0.21 & 0.20 & 0.26 & 0.03 & 0.24 \\
\hline & - & - & & - & & - & \\
\hline Cert. II & 0.03 & 0.09 & 0.36 & 0.12 & 0.31 & 0.09 & 0.14 \\
\hline & & - & - & 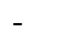 & - & & - \\
\hline Cert. III & 0.04 & 0.01 & 0.01 & 0.07 & 0.06 & 0.11 & 0.01 \\
\hline Cert. IV & 0.35 & 0.43 & 0.09 & 0.07 & 0.18 & 0.07 & 0.11 \\
\hline & & - & & - & - & & - \\
\hline Diploma+ & 0.04 & 0.04 & 0.14 & 0.47 & 0.10 & 0.06 & 0.11 \\
\hline & - & - & . & & & & \\
\hline Cert. I & 0.32 & 0.20 & 0.31 & 0.03 & 0.29 & 0.42 & 0.34 \\
\hline $\mathrm{C}$ & 04 & 01 & 9 & 9 & 009 & 0 & \\
\hline 1. 11 & .04 & 01 & & - & & - & \\
\hline Cert. III & 0.24 & 0.25 & 0.10 & 0.09 & 0.12 & 0.10 & 0.14 \\
\hline & & 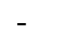 & - & 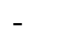 & & 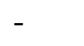 & 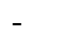 \\
\hline Cert. IV & 0.05 & 0.58 & 0.09 & 0.11 & 0.26 & 0.22 & 0.23 \\
\hline
\end{tabular}


Public Health

Rehabilitation Therapies

Rehabilitation Therapies

Rehabilitation Therapies

Rehabilitation Therapies

Rehabilitation Therapies

Sales and Marketing

Sales and Marketing

Sales and Marketing

Sales and Marketing

Sales and Marketing

Social Skills Programmes

Social Skills Programmes

Social Skills Programmes

Social Skills Programmes

Social Skills Programmes

Sport and Recreation

Sport and Recreation

Sport and Recreation

Sport and Recreation

Sport and Recreation

Teacher Education

Teacher Education

Teacher Education

Teacher Education

Teacher Education

Tourism

Tourism

Tourism

Tourism $\begin{array}{llllllll}\text { Diploma+ } & 0.78 & 0.68 & - & 0.30 & 0.12 & 0.24 & 0.31 \\ & - & - & - & & & - & - \\ \text { Cert. I } & 0.12 & 0.21 & 0.20 & 0.26 & 0.22 & 0.91 & 0.07\end{array}$

$\begin{array}{llllllll}\text { Cert. I } & 0.12 & 0.21 & 0.20 & 0.26 & 0.22 & 0.91 & 0.07\end{array}$

$\begin{array}{llllllll}\text { Cert. II } & 0.31 & 0.23 & 0.49 & 0.06 & 0.04 & 0.01 & 0.03\end{array}$

$\begin{array}{llllllll}\text { Cert. III } & 0.03 & 1.01 & 0.06 & 0.07 & 0.13 & 0.04 & 0.02\end{array}$

$\begin{array}{llllllll}\text { Cert. IV } & 0.05 & 0.26 & 0.11 & 0.11 & 0.05 & 0.16 & 0.26\end{array}$

$\begin{array}{llllllll}\text { Diploma+ } & 0.78 & 0.68 & - & 0.30 & 0.12 & 0.24 & 0.31\end{array}$

$\begin{array}{llllllll}\text { Cert. I } & 0.01 & 0.03 & 0.01 & 0.06 & 0.00 & 0.09 & 0.03\end{array}$

$\begin{array}{llllllll}\text { Cert. II } & 0.08 & 0.01 & 0.05 & 0.07 & 0.07 & 0.06 & 0.12\end{array}$

$\begin{array}{llllllll}\text { Cert. III } & 0.02 & 0.10 & 0.14 & 0.20 & 0.19 & 0.13 & 0.13\end{array}$

$\begin{array}{llllllll}\text { Cert. IV } & 0.07 & 0.20 & 0.14 & 0.33 & 0.23 & 0.22 & 0.27\end{array}$

$\begin{array}{llllllll}\text { Diploma+ } & 0.10 & 0.25 & 0.42 & 0.45 & 0.34 & 0.21 & 0.50\end{array}$

$\begin{array}{llllllll}\text { Cert. I } & - & 0.49 & 0.25 & 0.48 & 0.30 & 0.17 & 0.13\end{array}$

$\begin{array}{llllllll}\text { Cert. II } & 0.07 & 0.44 & 0.00 & 1.08 & 0.26 & 0.02 & 0.29\end{array}$

$\begin{array}{llllllll}\text { Cert. III } & 0.68 & 0.28 & 0.36 & 0.11 & 0.17 & 0.17 & 0.13\end{array}$

$\begin{array}{llllllll}\text { Cert. IV } & 0.42 & 0.49 & 0.11 & 0.23 & 0.03 & 0.19 & 0.11\end{array}$

$\begin{array}{llllllll}\text { Diploma+ } & 1.76 & 0.39 & 0.61 & 0.20 & 0.30 & 0.16 & 0.67\end{array}$

$\begin{array}{llllllll}\text { Cert. I } & 0.09 & 0.23 & 0.02 & 0.10 & 0.11 & 0.05 & 0.15\end{array}$

$\begin{array}{llllllll}\text { Cert. II } & 0.09 & 0.04 & 0.11 & 0.27 & 0.11 & 0.03 & 0.09\end{array}$

$\begin{array}{llllllll}\text { Cert. III } & 0.06 & 0.08 & 0.11 & 0.19 & 0.13 & 0.15 & 0.15\end{array}$

$\begin{array}{llllllll}\text { Cert. IV } & 0.29 & 0.03 & 0.25 & 0.49 & 0.33 & 0.17 & 0.65\end{array}$

$\begin{array}{llllllll}\text { Diploma+ } & 0.45 & 0.33 & 0.24 & 0.83 & 0.59 & 1.17 & 0.34\end{array}$

$\begin{array}{lllllllll}\text { Cert. I } & 0.30 & 0.54 & 0.11 & - & 0.14 & 0.68 & 0.25\end{array}$

$\begin{array}{llllllll}\text { Cert. II } & 0.13 & 0.16 & 0.08 & 0.10 & 0.10 & 0.10 & 0.01\end{array}$

$\begin{array}{llllllll}\text { Cert. III } & 0.15 & 0.60 & 0.06 & 0.10 & 0.06 & 0.06 & 0.03\end{array}$

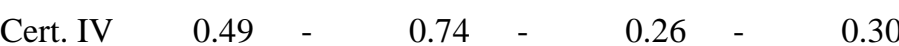

$\begin{array}{llllllll}\text { Diploma+ } & - & - & 0.30 & - & 0.09 & 0.58 & 0.85\end{array}$

$\begin{array}{llllllll}\text { Cert. I } & 0.09 & 0.04 & 0.97 & 0.03 & 0.01 & 0.62 & 0.03\end{array}$

$\begin{array}{llllllll}\text { Cert. II } & 0.29 & 0.02 & 0.05 & 0.89 & 0.37 & 0.23 & 0.03\end{array}$

$\begin{array}{llllllll}\text { Cert. III } & 0.05 & 0.03 & 0.13 & 0.13 & 0.14 & 0.01 & 0.16\end{array}$

$\begin{array}{llllllll}\text { Cert. IV } & 0.07 & 0.07 & 0.10 & 0.41 & 0.15 & 0.09 & 0.02\end{array}$ 


\begin{tabular}{|c|c|c|c|c|c|c|c|c|}
\hline & & & & & & & & \\
\hline Tourism & Diploma+ & 0.06 & 0.29 & 0.28 & 0.37 & 0.29 & 0.33 & 0.25 \\
\hline Veterinary Studies & Cert. I & 0.45 & 0.30 & 0.21 & 0.29 & 0.51 & 0.51 & 0.26 \\
\hline & & & & & & - & - & - \\
\hline Veterinary Studies & Cert. II & 0.10 & 0.08 & 0.13 & 0.14 & 0.04 & 0.02 & 0.07 \\
\hline & & & - & - & - & - & - & - \\
\hline Veterinary Studies & Cert. III & 0.14 & 0.01 & 0.16 & 0.10 & 0.22 & 0.06 & 0.15 \\
\hline & & & - & - & - & - & - & - \\
\hline Veterinary Studies & Cert. IV & 0.00 & 0.19 & 0.10 & 0.11 & 0.12 & 0.14 & 0.30 \\
\hline & & & - & & - & - & - & - \\
\hline Veterinary Studies & Diploma+ & 0.78 & 0.71 & - & 0.34 & 0.15 & 0.26 & 0.32 \\
\hline & & - & - & - & - & - & - & - \\
\hline Visual Arts and Crafts & Cert. I & 0.12 & 0.11 & 0.20 & 0.37 & 0.24 & 0.42 & 0.20 \\
\hline & & - & - & - & & - & - & - \\
\hline Visual Arts and Crafts & Cert. II & 0.13 & 0.24 & 0.07 & 0.04 & 0.28 & 0.26 & 0.29 \\
\hline & & & - & - & - & - & - & - \\
\hline Visual Arts and Crafts & Cert. III & 0.04 & 0.13 & 0.27 & 0.09 & 0.32 & 0.36 & 0.29 \\
\hline & & - & & - & - & - & - & - \\
\hline Visual Arts and Crafts & Cert. IV & 0.21 & 0.21 & 0.28 & 0.04 & 0.23 & 0.16 & 0.33 \\
\hline & & - & & - & - & & - & - \\
\hline Visual Arts and Crafts & Diploma+ & 0.89 & 0.74 & 0.42 & 0.35 & 0.51 & 2.02 & 0.54 \\
\hline
\end{tabular}

:These estimates are from a log wage regression model estimated on those aged 15-25 at the time of survey (around six months after completing their VET course) and who are not in study at the time of survey (used to generate our measure for expected course returns, adjusted for student characteristics). The dependent variable is weekly wage in 2013 Australian dollar terms, adjusted using the 2007-2013 wage price index by state (Australian Bureau of Statistics 2013). All regression models are estimated with controls for age, gender, state and region of residence, full-time employment status, disability status, highest prior education status, indigenous status, whether from a non-English speaking background, English speaking proficiency, employment status prior to study, whether training is part of an apprenticeship/traineeship and whether first job after finishing training. The reference case is Building Certificate level III, which was chosen because of the large number of observations and because it is a qualification that is easily recognisable (the typical qualification attained to become a builder in Australia). The size of the sample doubles every two years.

- is insufficient number of observations in the Student Outcome Survey to estimate results at the ISCED 4-digit and course level and ref. is reference case in the estimation (Building, Certificate III).

Source: Student Outcome Survey 2007, 2008, 2009 and 2010.

\section{Table A4: Differences in trends between Victoria and the rest of Australia during the pre-treatment period}

\begin{tabular}{|c|c|c|c|c|}
\hline \multirow{2}{*}{$\begin{array}{l}\text { Model coefficient } \\
\delta_{p}\end{array}$} & \multicolumn{2}{|l|}{ Course choice } & \multicolumn{2}{|c|}{ Course completion } \\
\hline & $\begin{array}{l}\text { National skill } \\
\text { shortage }\end{array}$ & $\begin{array}{l}\text { Expected } \\
\text { graduate earnings }\end{array}$ & $\begin{array}{l}\text { Module } \\
\text { completion }\end{array}$ & $\begin{array}{l}\text { Course } \\
\text { completion }\end{array}$ \\
\hline 2006 & ref. case & ref. case & ref. case & ref. case \\
\hline \multirow[t]{2}{*}{2007} & 0.000 & $-0.037 * * *$ & $-0.015 * *$ & $-0.031 *$ \\
\hline & $(0.008)$ & $(0.004)$ & $(0.006)$ & $(0.015)$ \\
\hline \multirow[t]{2}{*}{2008} & $-0.031 * *$ & -0.005 & -0.008 & $-0.065 * * *$ \\
\hline & $(0.012)$ & $(0.006)$ & $(0.014)$ & $(0.018)$ \\
\hline \multirow[t]{2}{*}{2009} & $-0.023^{*}$ & $-0.015^{* *}$ & -0.025 & $-0.055^{* *}$ \\
\hline & $(0.011)$ & $(0.006)$ & $(0.016)$ & $(0.018)$ \\
\hline$F_{\delta_{2007}=\delta_{2008}}=\delta_{2009}=0$ & $6.95 * *$ & $43.79 * * *$ & $75.88 * * *$ & $19.73 * * *$ \\
\hline Count & 783,289 & 835,455 & 838,748 & 854,023 \\
\hline
\end{tabular}


Table A5: Courses that averaged more than a 500 per year student increase in enrolment in Victoria following the VTG

\begin{tabular}{|c|c|c|c|c|c|c|c|c|}
\hline \multirow[t]{2}{*}{ Course name } & \multirow[t]{2}{*}{ Level } & \multirow[t]{2}{*}{ Field of study } & \multirow[t]{2}{*}{ Associated occupation } & \multirow[t]{2}{*}{$\begin{array}{l}\text { Post- } \\
\text { reform } \\
\text { years in } \\
\text { shortage }\end{array}$} & \multicolumn{4}{|c|}{$\begin{array}{l}\text { Change in average annual enrolment post- } \\
\text { reform (2010-12) relative to pre-reform (2006- } \\
2009)\end{array}$} \\
\hline & & & & & Public & Private & Total & $\%$ \\
\hline Hospitality & Cert. III & General Education & n.a. & n.a. & 1384 & 2135 & 3519 & 247 \\
\hline General Education For Adults & Cert. II & General Education & n.a. & n.a. & 3133 & 160 & 3292 & 131 \\
\hline Vocational Preparation & Cert. I & General Education & n.a. & n.a. & 1790 & 833 & 2623 & - \\
\hline General Education For Adults & Cert. I & General Education & n.a. & n.a. & 2447 & -5 & 2442 & 109 \\
\hline Hospitality & Cert. II & Food and Hospitality & n.a. & n.a. & 1505 & 924 & 2429 & 129 \\
\hline Carpentry & Cert. III & Building & Carpenters and Joiners & 0 & 1574 & 461 & 2035 & 8481 \\
\hline Retail & Cert. III & Sales and Marketing & Sales Assistants (General) & 0 & 431 & 1557 & 1988 & 298 \\
\hline Retail & Cert. II & $\begin{array}{l}\text { Sales and Marketing } \\
\text { Human Welfare }\end{array}$ & Sales Assistants (General) & 0 & 546 & 1405 & 1951 & 120 \\
\hline Children's Services & Cert. III & Studies and Services & $\begin{array}{l}\text { Child Carers } \\
\text { Building and Plumbing }\end{array}$ & 3 & 1299 & 578 & 1876 & 8934 \\
\hline Construction & Cert. I & $\begin{array}{l}\text { Building } \\
\text { Business and }\end{array}$ & Labourers & 0 & 1266 & 8 & 1275 & - \\
\hline Business Administration & Cert. IV & Management & Office Managers & 0 & 184 & 1024 & 1208 & 581 \\
\hline Business Administration & Cert. III & Office Studies & General Clerks & 0 & 321 & 849 & 1170 & 159 \\
\hline $\begin{array}{l}\text { Business } \\
\text { General Education For Adults }\end{array}$ & Cert. II & Office Studies & General Clerks & 0 & 327 & 809 & 1136 & 113 \\
\hline (Introductory) & Cert. I & General Education & n.a. & n.a. & 1132 & -3 & 1129 & 157 \\
\hline Plumbing & Cert. III & Building & Plumbers & 2 & 1048 & 49 & 1097 & 4220 \\
\hline Hairdressing & Cert. III & $\begin{array}{l}\text { Personal Services } \\
\text { Electrical and } \\
\text { Electronic Engineering }\end{array}$ & Hairdressers & 3 & 559 & 434 & 993 & - \\
\hline $\begin{array}{l}\text { Electrotechnology Electrician } \\
\text { Victorian Certificate Of Applied }\end{array}$ & Cert. III & and Technology & Electricians & 1 & 831 & 153 & 984 & 114 \\
\hline Learning (Foundation) & Cert. I & General Education & n.a. & n.a. & 876 & 27 & 903 & - \\
\hline General Education For Adults & Cert. III & General Education & n.a. & n.a. & 784 & 75 & 859 & 118 \\
\hline
\end{tabular}




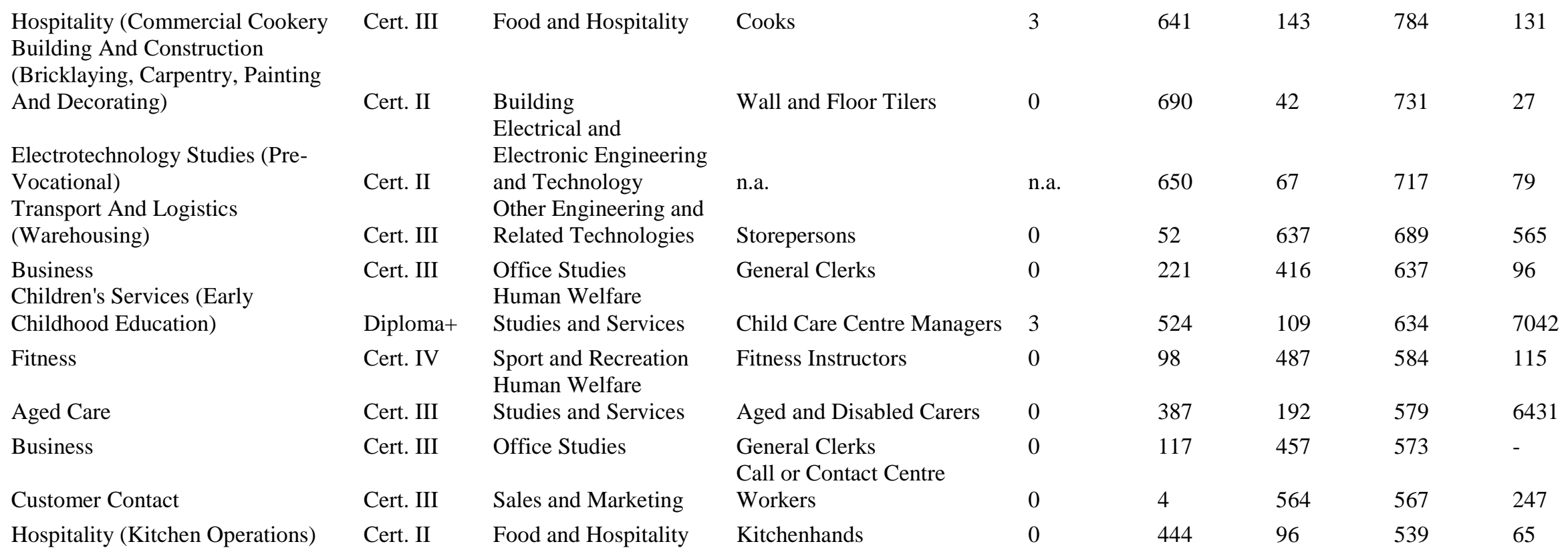

All Courses

$19007 \quad 13606 \quad 32613$

53

There are VET 3742 courses with at least one enrolled student between 2006 and 2012 in Australia. n.a. no appropriate, either because the course is a general course or because there is no one occupation that the course is designed to prepare students for. - could not be estimated because there were no enrolments pre-reform. 
Table A6: Impacts of VTG on graduate annual earnings from courses associated with skill shortage areas, standard counterfactual trend assumptions

Constant treatment effect

Time-varying treatment effect

2010

2011
$-0.064 * * *$

$(0.015)$

$-0.038$

$-0.076^{* *}$

(0.030)

72,436

Count

***Significant at 1\%,**significant at 5\% and *significant at 10\%. Standard errors are robust-clustered at the state and territory level with critical values based on T(8-1) distribution. The results are from difference-in-difference estimation of annual earnings from the national Student Outcome Survey (SOS) VET graduate data of 16- 25 year-olds for 2005-2011. The estimated effects of the reforms on graduate earnings represent the coefficients on three-way interactions between a post-reform dummy (or post-reform year dummy), a dummy of whether the student was a graduate from a course that was associated with an occupation on the previous year's skill shortage list and dummy for the state of Victoria. All models control for socio-economic background, highest prior education, employment status prior to study, current employment status, age in years, state, region and year fixed effects, qualification level attained, gender and indigenous and disability status.

Table A7: Difference-in-differences estimates for course choice outcomes using skill demand information in 2012 that is available at the time of enrolment in 2011, standard counterfactual trend assumptions

\begin{tabular}{|c|c|c|c|c|c|c|}
\hline & \multicolumn{2}{|c|}{ Unconditional } & \multicolumn{2}{|c|}{$\begin{array}{l}\text { With individual } \\
\text { controls }\end{array}$} & \multicolumn{2}{|c|}{$\begin{array}{l}\text { With individual and } \\
\text { provider controls }\end{array}$} \\
\hline & $\begin{array}{l}\text { National } \\
\text { skill } \\
\text { shortage }\end{array}$ & $\begin{array}{l}\text { Expected } \\
\text { earnings }\end{array}$ & $\begin{array}{l}\text { National } \\
\text { skill } \\
\text { shortage }\end{array}$ & $\begin{array}{l}\text { Expected } \\
\text { earnings }\end{array}$ & $\begin{array}{l}\text { National } \\
\text { skill } \\
\text { shortage }\end{array}$ & $\begin{array}{l}\text { Expected } \\
\text { earnings }\end{array}$ \\
\hline Constant treatment effect & $\begin{array}{l}0.031 * * * \\
(0.005)\end{array}$ & $\begin{array}{l}0.026 * * * \\
(0.006)\end{array}$ & $\begin{array}{l}0.029 * * * \\
(0.004)\end{array}$ & $\begin{array}{l}0.030 * * * \\
(0.005)\end{array}$ & $\begin{array}{l}0.027 * * \\
(0.008)\end{array}$ & $\begin{array}{l}0.030 * * * \\
(0.006)\end{array}$ \\
\hline $\begin{array}{l}\text { Time-varying treatment } \\
\text { effect }\end{array}$ & & & & & & \\
\hline 2010 & $\begin{array}{l}0.030^{* * *} \\
(0.007)\end{array}$ & $\begin{array}{l}0.017 * * \\
(0.007)\end{array}$ & $\begin{array}{l}0.025^{* * * *} \\
(0.005)\end{array}$ & $\begin{array}{l}0.018^{* *} \\
(0.007)\end{array}$ & $\begin{array}{l}0.023 * * \\
(0.007)\end{array}$ & $\begin{array}{l}0.018^{* *} \\
(0.007)\end{array}$ \\
\hline 2011 & $\begin{array}{l}0.020^{* *} \\
(0.007)\end{array}$ & $\begin{array}{l}0.022 * \\
(0.010)\end{array}$ & $\begin{array}{l}0.022 * * * \\
(0.005)\end{array}$ & $\begin{array}{l}0.027 * * \\
(0.009)\end{array}$ & $\begin{array}{l}0.020^{*} \\
(0.009)\end{array}$ & $\begin{array}{l}0.028^{* *} \\
(0.010)\end{array}$ \\
\hline 2012 & $\begin{array}{l}0.046^{* * * *} \\
(0.007)\end{array}$ & $\begin{array}{l}0.037 * * * \\
(0.006)\end{array}$ & $\begin{array}{l}0.043 * * * \\
(0.008)\end{array}$ & $\begin{array}{l}0.041 * * * \\
(0.006)\end{array}$ & $\begin{array}{l}0.039 * * \\
(0.012)\end{array}$ & $\begin{array}{l}0.041 * * * \\
(0.007)\end{array}$ \\
\hline Count & $1,405,010$ & $1,596,470$ & $1,400,325$ & $1,591,079$ & $1,399,907$ & $1,590,630$ \\
\hline
\end{tabular}

***Significant at $1 \%, * *$ significant at $5 \%$ and *significant at $10 \%$. Standard errors are robust-clustered at the state and territory level with critical values based on $\mathrm{T}(8-1)$ distribution. 
Table A8: Results for the sensitivity analysis, 2010-2012, under alternative counterfactual trend assumptions ${ }^{\mathrm{a}}$ with full set of controls

\begin{tabular}{|c|c|c|c|c|}
\hline & $\begin{array}{l}\text { National skill } \\
\text { shortage }\end{array}$ & $\begin{array}{l}\text { Course } \\
\text { graduate } \\
\text { wage }\end{array}$ & $\begin{array}{l}\text { Module } \\
\text { completion }\end{array}$ & $\begin{array}{l}\text { Course } \\
\text { completion }\end{array}$ \\
\hline \multirow[t]{2}{*}{ Standard estimates (Tables 3 and 5) } & $0.047 * * *$ & $0.033 * * *$ & $0.026 * * *$ & $0.041 * * *$ \\
\hline & $(0.013)$ & $(0.008)$ & $(0.007)$ & $(0.010)$ \\
\hline Enrolments restricted to Albury and Wodonga & $0.078 * * *$ & $0.062 * * *$ & $0.068 * * *$ & $0.039 * * *$ \\
\hline local government areasa & $(0.002)$ & $(0.002)$ & $(0.012)$ & $(0.001)$ \\
\hline \multirow[t]{2}{*}{ Restrict to $18-19$ year-olds } & $0.061 *$ & $0.033 * * *$ & $0.026 * * *$ & $0.053 * * *$ \\
\hline & $(0.031)$ & $(0.008)$ & $(0.005)$ & $(0.011)$ \\
\hline \multirow[t]{2}{*}{ Omit enrolments from August 2008 to December 2009} & $0.052 * * *$ & $0.064 * * *$ & - & - \\
\hline & $(0.015)$ & $(0.011)$ & - & - \\
\hline \multirow[t]{2}{*}{ Omit enrolments from July 2012} & $0.051 * * *$ & $0.041 * * *$ & $0.029 * * *$ & $0.040 * * *$ \\
\hline & $(0.013)$ & $(0.008)$ & $(0.008)$ & $(0.011)$ \\
\hline \multirow[t]{2}{*}{ Include college fixed effects } & $0.049 * * *$ & $0.049 * * *$ & & \\
\hline & $(0.010)$ & $(0.008)$ & & \\
\hline \multirow[t]{2}{*}{ Include college and provider fixed effects } & - & - & $0.019 * *$ & $0.037 * * *$ \\
\hline & - & - & $(0.006)$ & $(0.007)$ \\
\hline \multirow[t]{2}{*}{ Excluding fee-for-service courses } & $0.038 *$ & $0.048 * * *$ & $0.034 * * *$ & $0.041 * *$ \\
\hline & $(0.018)$ & $(0.007)$ & $(0.007)$ & $(0.012)$ \\
\hline \multirow[t]{2}{*}{ Excluding courses not linked to an occupation } & - & $0.032 * * *$ & - & - \\
\hline & - & $(0.005)$ & - & - \\
\hline \multirow[t]{2}{*}{ Excluding expected wages with missing 4-digit cells } & - & $0.045 * * *$ & - & - \\
\hline & - & $(0.008)$ & - & - \\
\hline \multirow[t]{2}{*}{ Wild bootstrapped standard errors } & $0.047 * * *$ & $0.033 * * *$ & $0.026 * *$ & $0.041 * * *$ \\
\hline & $(0.000)$ & $(0.000)$ & $(0.012)$ & $(0.000)$ \\
\hline
\end{tabular}

***Significant at $1 \%, * *$ significant at $5 \%$ and $*$ significant at $10 \%$. Unless otherwise stated, results are generated with a full set of student and college controls with state cluster-robust standard errors and critical values from T(8-1) distribution.

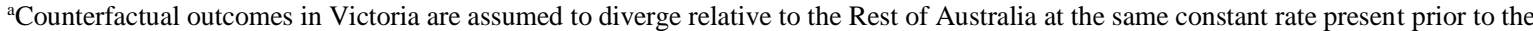
reform (2006-09). ${ }^{\mathrm{b}}$ Local government areas (LGAs) is an Australian standard geographical classification that covers the administrative boundaries of local governments, similar to counties in the United States. The LGAs of Albury (in Victoria) and Wodonga (in NSW) are divided by the Murray River, which is the Victoria and NSW state border. This model is estimated on a sample size of 1962 and 3073 observations for national skill shortage and course graduate wage respectively. Standard errors are robust-clustered at the state level with $\mathrm{T}(2-1)$ critical values. ${ }^{c} \mathrm{We}$ use the cgmwildboot program (provided by Judson Caskey, https://sites.google.com/site/judsoncaskey/data) to estimate p-values based on wild bootsrapped standard errors clustered at the state and territory level with 1000 draws. The program produces p-values (reported in square brackets) that are based on empirical T(8-1) distribution. 


\section{References}

Australian Bureau of Statistics (ABS) (2001). 'Australian Standard Classification of Education (ASCED)', ABS cat. no. 1272.0, Canberra, Australia.

Australian Bureau of Statistics (2011a). 'Australian Statistical Geography Standard, volume 5, Remoteness Structure, July 2011', ABS cat. no. 1270.0.55.005, ABS, Canberra.

Australian Bureau of Statistics (2011b). 'Census of population and housing: Socio-economic indexes for areas (SEIFA)', ABS cat. no. 2033.0.055.001, ABS, Canberra.

Australian Bureau of Statistics (2013). 'Wage price index, Australia, September 2013', ABS cat. no. 6345.0, ABS, Canberra.

Australian Bureau of Statistics (2014a). 'Australian Demographic Statistics 2014', ABS cat. no. 3101.0, ABS, Canberra.

Australian Bureau of Statistics (2014b). 'Schools, Australia, 2013', ABS cat. no. 4221.0, Canberra, Australia.

Australian Qualifications Framework Council (AQFC) (2013). 'Australian qualifications framework, second edition', AQFC, Adelaide.

United National Educational, Scientific and Cultural Organisation (UNESCO) (2006). International Standard Classification of Education, ISCED 1007, UNESCO, Montréal. 